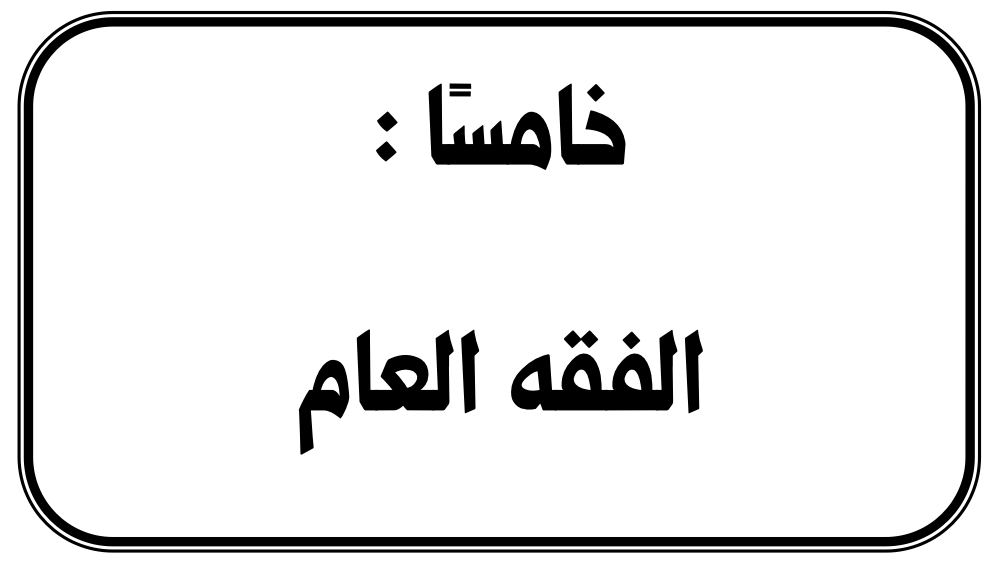





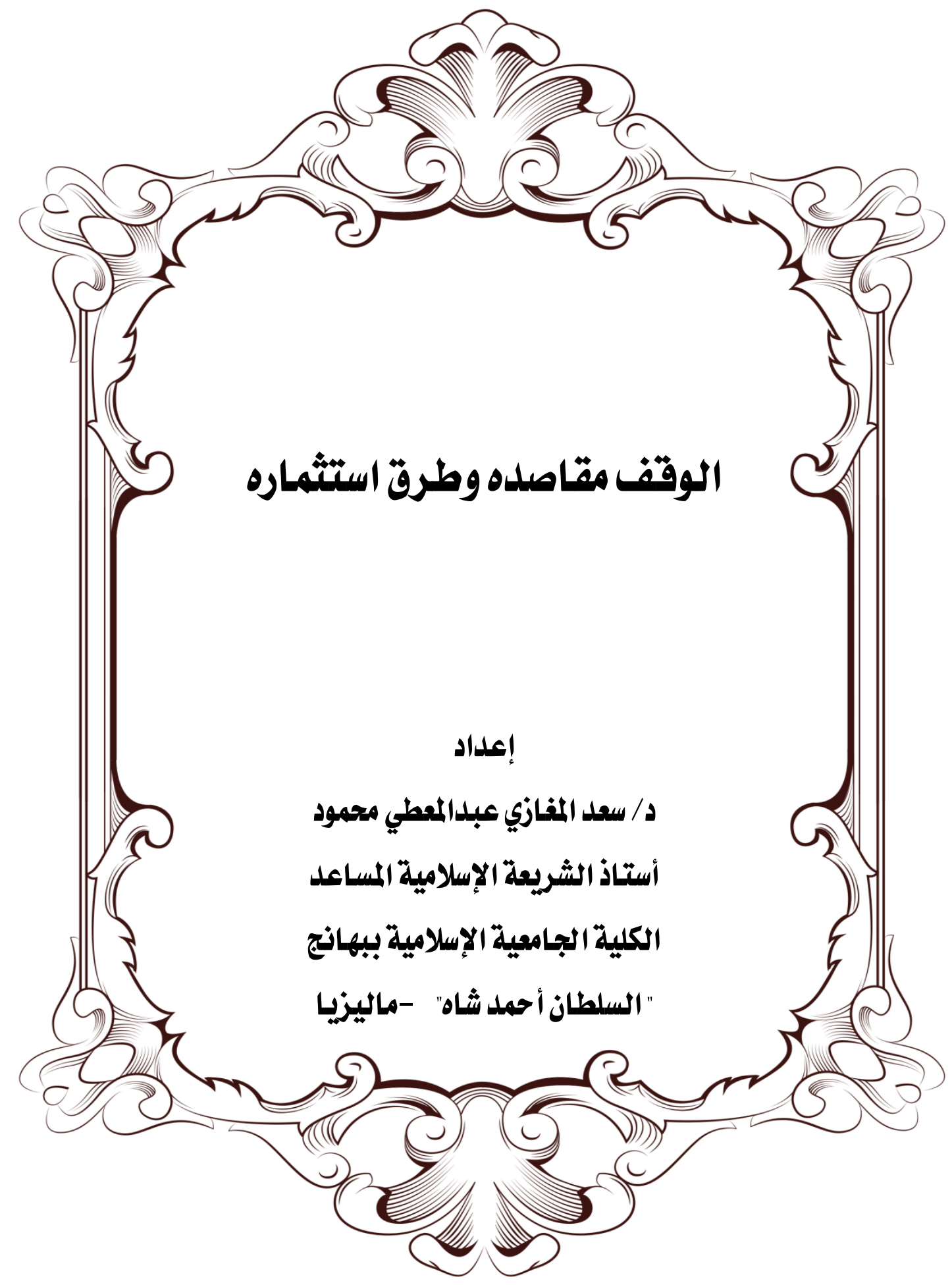


الوقف مقاصده وطرق استثماره

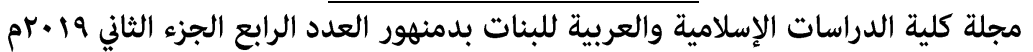


الوقف مقاصده وطرق استثماره

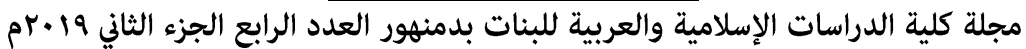

الوقف مقاصده وطرق استثماره

سعد المغازي عبدالمعطي محمود الدمازي

الكلية الجامعية الإسلامية ببهانج " السلطان

أحمد شاه"-ماليزيا الإهياه

Dr_saadabdelmoty@gmail.com

ملخص عن بحث الوقف باللغة العربية

يتكون هذا البحث من أربعة مباحث وخاتمة.

المبحث الأول تكلمت فيه عن ماهية الوقف وأهميته فى كافة المجالاته

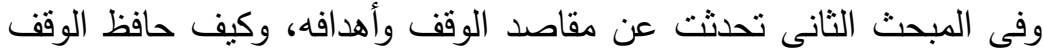

على مقاصد الثريعة عبر التاريخ، ودوره العظيم فى دعم كافة الأنشطة لأداء

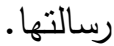

وفى المبحث الثالث وضحت استثمار الوقف ومجالات الاستثمار ،سواء

الطرق التقليدية من الإجارة والمضاربة والمزارعة،أو الطرق الحديثة من المرابحة

والصكوك وسندات الاستثمار .

وفى المبحث الرابع تتاولت إدارة الوقف، وصيانته والعناية به:ليؤدى وظيفته

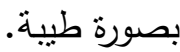

وأخيرا نتائج البحث وذكرت أهم ما توصلت إليه من نتائج.

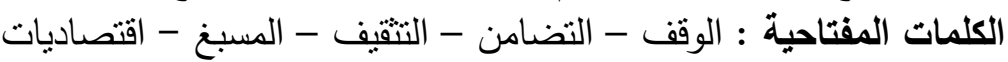

Summary of Waqf research in English Language

This research consists of four investigations and a conclusion.

The first topic I spoke about the nature of the stay and its importance in all areas.

In the second part, I spoke about the objectives and objectives of the Waqf, and how the Waqf has maintained the purposes of the Shari'ah throughout history and its great role in supporting all activities to fulfill its mission. In the third topic, the investment of the Waqf and investment fields, whether traditional methods of leasing, speculation and agriculture, or the modern methods of Murabaha, sukuk and investment bonds

In the fourth topic dealt with the management of the Waqf, and maintenance and care for him; to do his job well.

And finally the results of the research and reported the most important finding

Key words: endowment - solidarity - education - what is required economics 


\section{الوقف مقاصده وطرق استثماره}

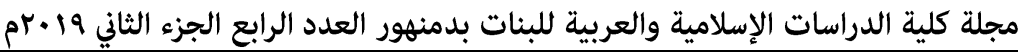

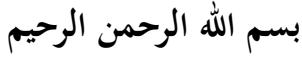

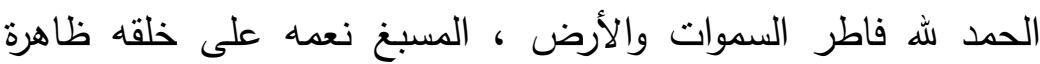

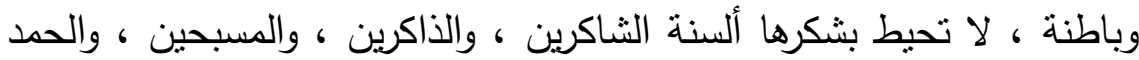
لله الذى اصطفى من عباده النبي الأمى رسولا إلى العالمين ، وأوحي إليه هذا القرآن ، بلسان عربي مبين ، يكون ذكرا له ولقومه دهر الداهرين •

ويعد

فيعد الوقف من مفاخر الحضارة الإسلامية ؛ لما لعبه من دور في نهضتها في كافة المجالات التعليمية ، والاجتماعية ، والاقتصادية والسياسية . فبه ازدهرت الحضارة الإسلامية في عصورها المختلفة ، ومازالت شواهده حاضرة في الحواضر الكبرى للعالم الإسلامى كالقاهرة ودمشق وبغداد ، والقيروان ، وفاس في المغرب العربى ، تمثلت هذه الثواهد في المدارس والمستشفيات ، والأسبلة ، شاهدة على رقى هذه الحضارة ، وشموخها، وإنسانيتها.

وقد استفادت الأجيال المتعاقبة من نظام الوقف باعتباره آلية لحفظ المال ، واستثماره في نفس الوقت في وجوه الخير والبر • ونظام بهذا الثكل يلقى على كاهل من يقوم عليه تبعات كبيرة ومسؤليات جسيمة في المحافظة عليه بل وتتميته واستثماره ، ليحقق دوره

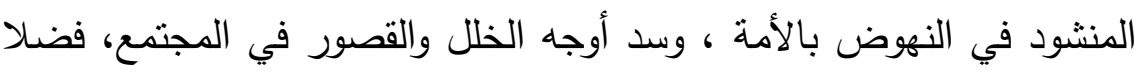
عن سد حاجة المحتاجين •

ورغم هذا فقد واجه الوقف مشاكل عديدة تمثلت في إدارته التى لم تكن كفؤة في كثير من الأحاييين ، مما أضاع جهودا كثيرة ، وبدد خيرات وفيرة ،

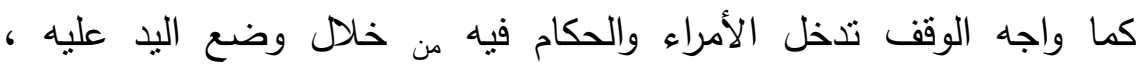
زاستغلاله على غير ما وضع له .

وتمتل إدارة الوقف في العصر الحاضر إحدى المعضلات التى نواجه القائمين على أمره في كيفية تعظيم شأن الوقف ، وتفعيله ، لتحقيق مردود

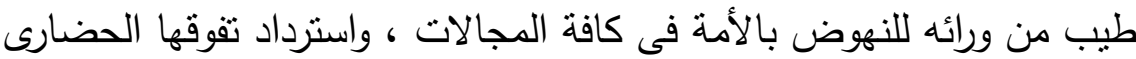

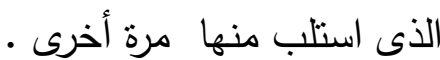


الوقف مقاصده وطرق استثهاره

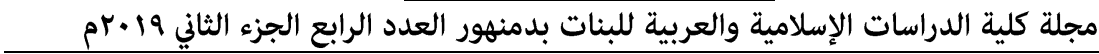

إثكالية البحث :- تحاول هذه الدراسة علي أن تجيب الني عالي النساؤلات الآتية:-

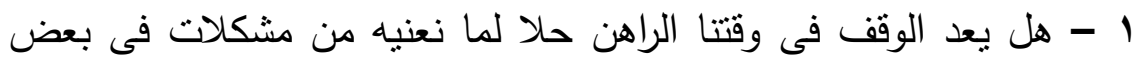

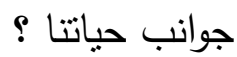

r - كيفية استثمار الوقف بطريقة تعظم العائد من ورائه ؟

r - إدارة الوقف بطريقة كفؤة ، ومعالجة السلبيات فى إدارته

وأتناول هذا البحث في المباحث التالية :-

المبحث الأول :- في ماهية الوقف وأهميته.

المبحث الثانى :- مقاصده وغاياته .

المبحث الثالث :- استثمار الوقف ومجالاته .

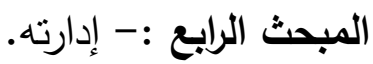

الخاتمة وفيها النتائج والتوصيات.

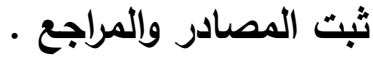

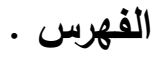




\section{الوقف مقاصده وطرق استثهاره}

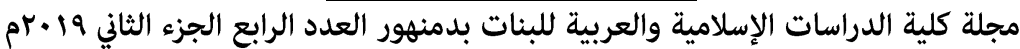

\section{المبحث الأول}

\section{تعريف الوقف وأهميته}

\section{تعريف الوقف :}

في اللغة: وقف وقوفا قام من جلوس ، وسكن بعد المشى والوقف بعنى

الحبس عن التصرف ، وحبس الثىئ وقفه فلا يباع ولا يورث ( ().

وفي الاصطلاح: منع التصرف في رقبة العين التى يمكن الانتفاع بها

مع بقاء عينها ، وجعل المنفعة لجهة من جهات الخير ابتذاء وانتهاء (Y). أهمبة الوقف :

لا شك أن الوقف من أجل أعمال الخير ، وله دوره في بناء مجتمع قوى متماسلك ، ويمكن أن يكون له دورا متزايدا فى الحياتين الاقتصادية ، والمالية

للمجتمع الإسلامى لو أحسن استخلاله ، ووضع له التظيم الجيد (r).

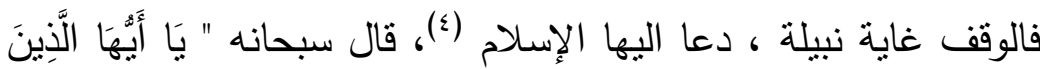

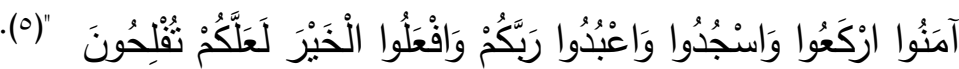

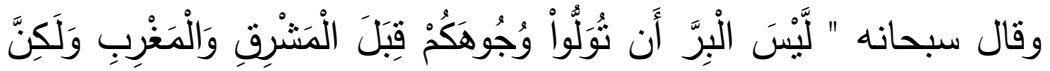

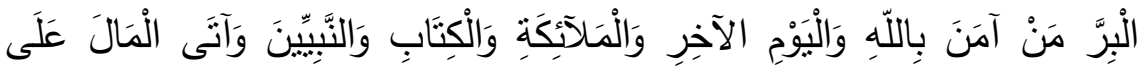

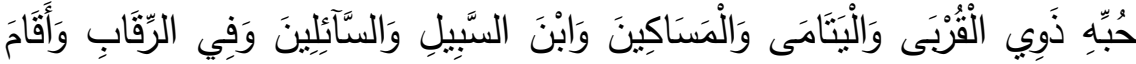

(1) (1) - لالان العرب - فصل الواو - باب الفاء ،مختار الصحاح - باب الفاء - فصل الواو.

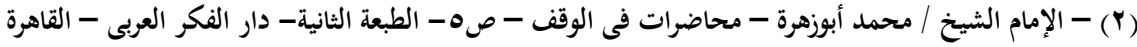

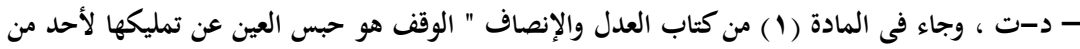

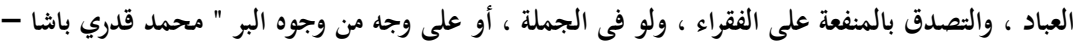

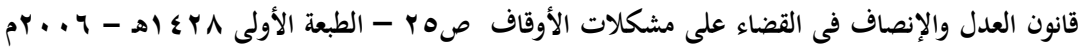
- دار الريان للطباعة والنشر - المكتبة المكية .

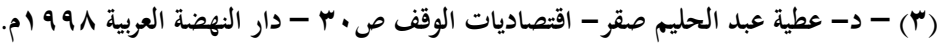

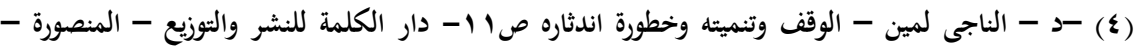

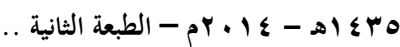

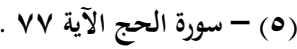




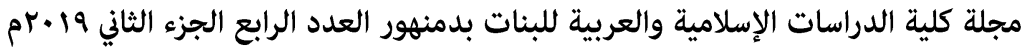

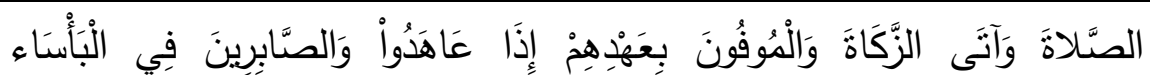

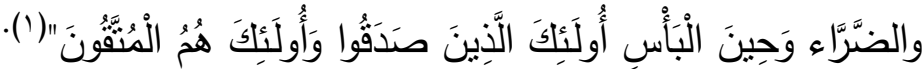

وفى الحديث " من نفس عن مؤمن من كربة من كرب الدنبا نفس الله

عنه كربة من كرب يوم القيامة "(r).

فمن يفعل الخير يراد به وجه الله لا أن يكون هدفا لأغراض أخرى ، لهن

بشره الله بمضاعفة ثوابه ، والخلف عليه (r).

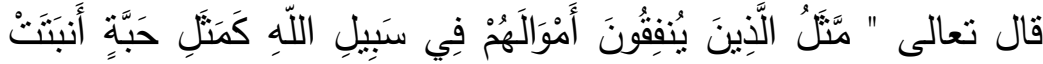

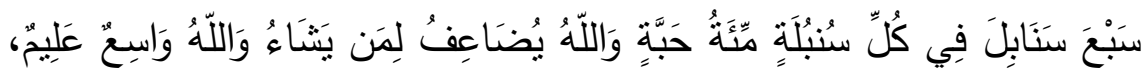

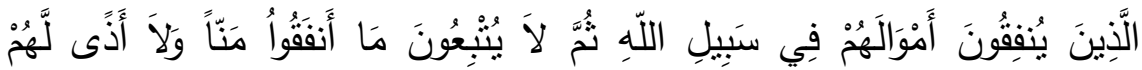

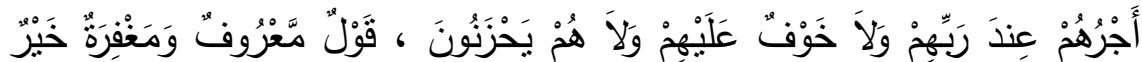

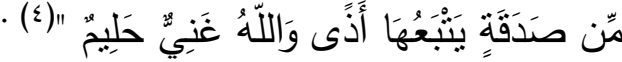

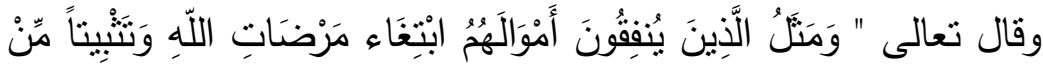

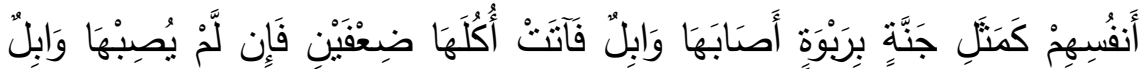

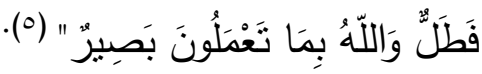

فالوقف من أهم مصادر العمل الخيرى ، لما فيه من حبس الأصل وتسبيل منفعته ، والانتفاع بها ، وهذه ميزة تجعل الوقف خيرا ناطقا ومنفعة

مستمرة ، ومُعْنا جاريا (T).

فالوقف يساهم في تتمية المجتمع ، وتقدمه وازدهاره ؛ نظرا لأنه يلبى احتياجاته الاقتصادية والأمنية والصحية ، والتعليمية والدينية ، ويقوى من

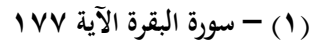

(Y) - الحديث فى صحيح مسلم باب تحريم الظلم ، وباب فضل الاجتماع على تلاوة القرآن ، وعلى الذكر الآدر

$$
\text { والحديث عن أبى هريرة . }
$$

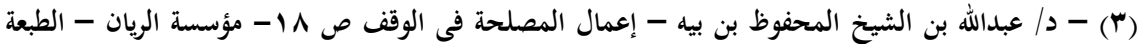

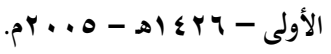

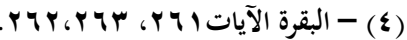

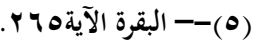

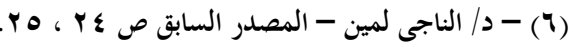




\section{الوقف مقاصده وطرق استثماره}

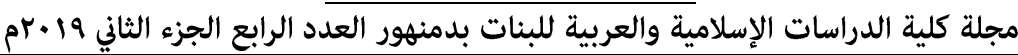

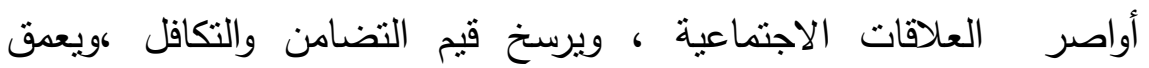

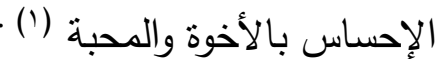

والوقف مصدر حيوى لمجالات خيرية كثثرة لا نشملها الزكاة

والصدقات ، كإنشاء مراكز للبحث العلمى ، ومراكز للاعوة والإششاد في البلاد

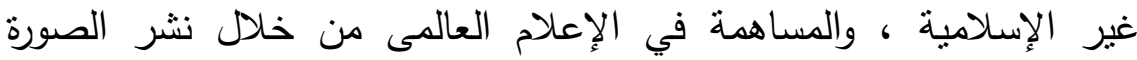

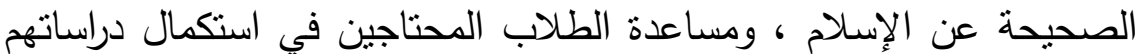

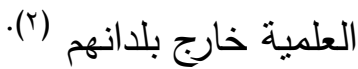

ولقد شكل الوقف على مدار تاريخه ركيزة أساسية في اقتصاديات الدول

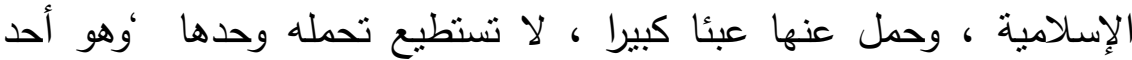
الأنظمة المالية الإسلامية ، التى تهدف الى تقوية الروابط الاجتماعية بين أفراد المجتمع ، فقد اشتملت أثثاره جوانب الحياة المختلفة اجتماعيا ودينيا وثقافيا واقتصاديا ،واكتسب أهمية خاصة لما قام به من دور بارز ، وفعال في استمرار

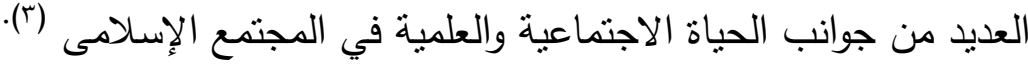

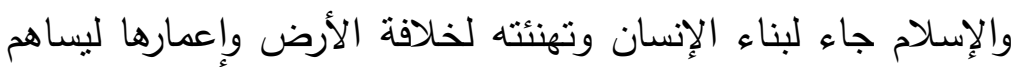

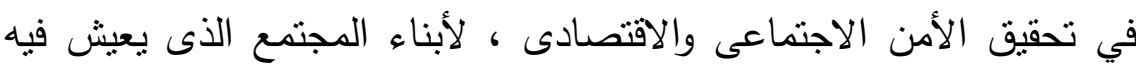

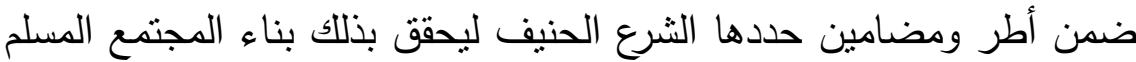
القائم على الإخاء والتعاون والتكافل ، فلقد شاء الله أن يجعل الناس مختلفين

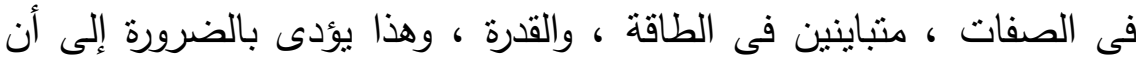

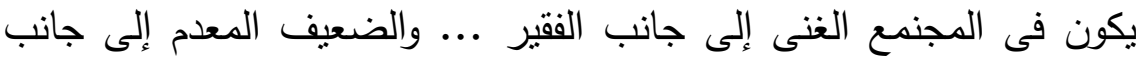
القوى الملئ ، وكان لا بد للثارع الحكيم وهو بصدي الفي تتظيم الحياة أن يأمر

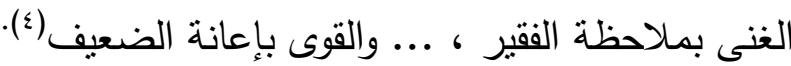

(1) - أحمد محمد عبدالعظيم الجمل - دور نظام الوقف الإسلامى - صه أ - دار السلام - الطبعة الأولى .

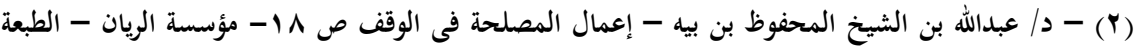

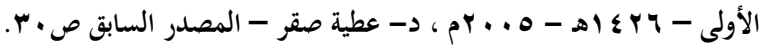

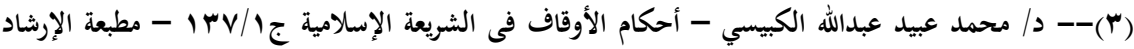

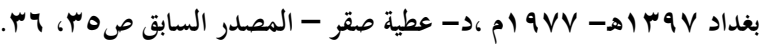

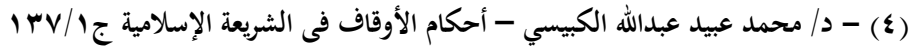




\section{الوقف مقاصده وطرق استثماره}

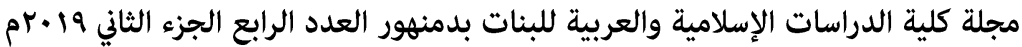

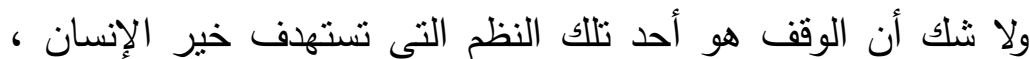

وتحقق له الأمن والطمأنينة والاستقرار (1).

فأغراض الوقف تعددت وتتوعت لنتمل كل جوانب الحياة تتتقع به كل

طبقات المجتمع المسلم ؛ فالوقف ارتبط ارتباطا شديدا بمختلف جوانب الحياة الاقتصادية والاجتماعية والثقافية والسباسية ، علاوة على ارتباطه العميق

بالجوانب الروحية والأخلاقية (r).

فالوقف نظام يحقق المصلحة العامة والخاصة ، وبرفع الضرر بل

يقدم الحاجات الضرورية ، بما فيه من تكريم للإنسان ومنع استغلاله ،وهذا بلا شك يتفق مع نصوص الثربعة، ومقاصدها الداعية إلى جلب المصالح ودرء المفاسد ،وهونظام اجتماعى تكافلى يتولى فيه الموسرون من المسلمين كفالة الفقراء والمحتاجين ، كفالة نشمل كل جوانب الحياة بما يرفع عن كاهل الدولة عبء تحمل مصاريف الرعاية الاجتماعية لفئات عريضة من أبنائها الذين يعانون وبلات الفقر والحاجة (r).

وتلخل الوقف بهذا الثكل من شأنه إيجاد مجتمع متضامن منكامل عصى على التفتت والانقسام ، تتلاشى فيه الصراعات ، مما بساعد في باء دولة قوية ، بما يوفر لها الوقف من فوائض مالية تسنثمر في جوانب أخرى لا تغطيها الأوقاف ، مما بساهم في البناء الحضارى ويحقق لها الخيرية والعزة

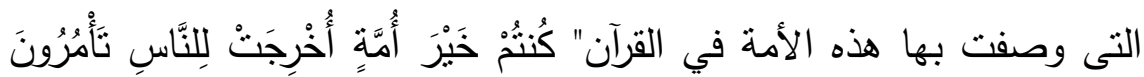

(1)- الشيخ / نور الدين مختارالخادمى - الوقف العالمى ( أحكامه وومقاصده - مشكلاته وآفاقه)

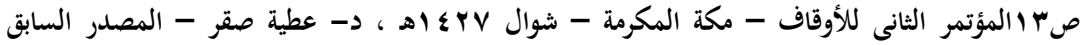
صץr.

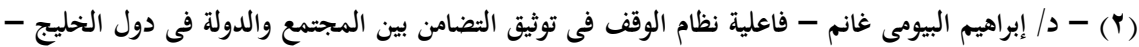

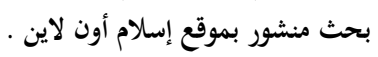

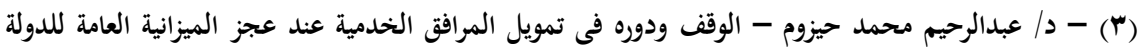

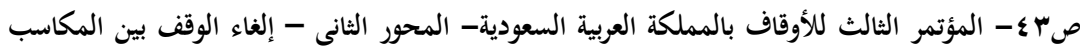

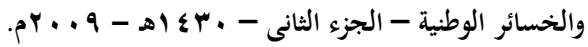




\section{الوقف مقاصده وطرق استثماره}

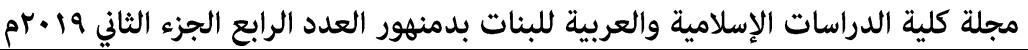

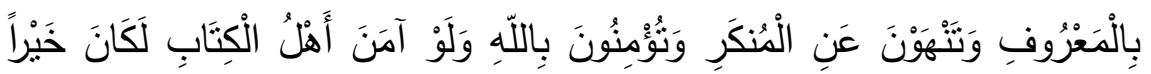

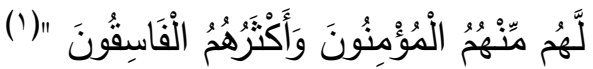

فالأوقاف انسعت دائرتها لنظلل مختلف جوانب الحياة ، وتقنن المسلمون

في أغراض الوقف ، بحيث لم تبق مصلحة اجتماعية أو منفعة عامة ، إلا الا

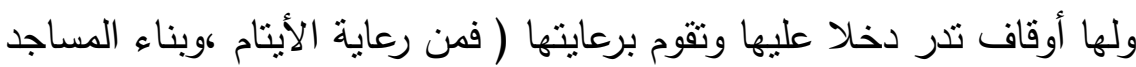

، وإمداد الناس بالمياه ، والتعليم ) (r).

بل لا نبالغ إذا قلنا أن الوقف كان له له دوره الكبير في توفير الضمانات

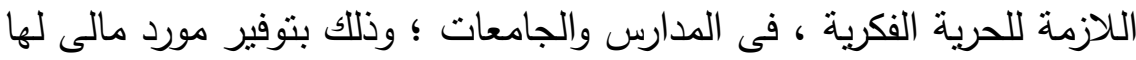

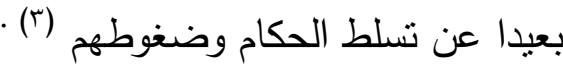

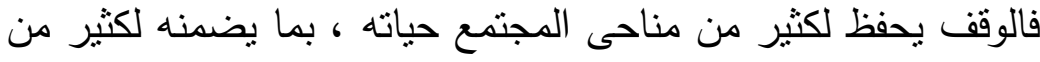

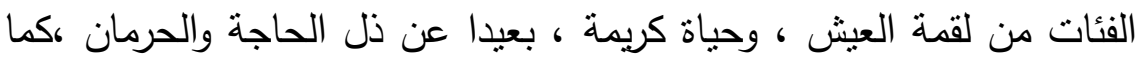

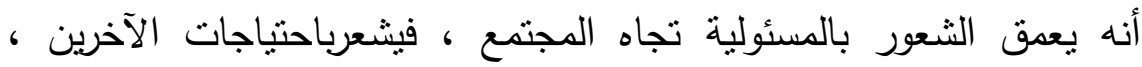

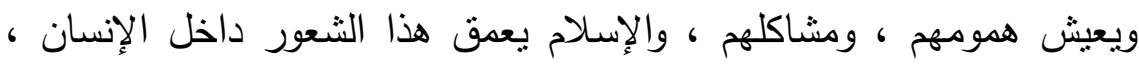

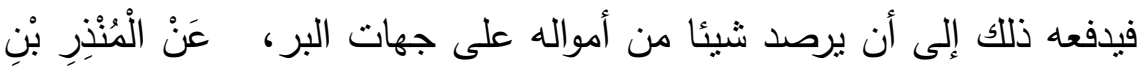

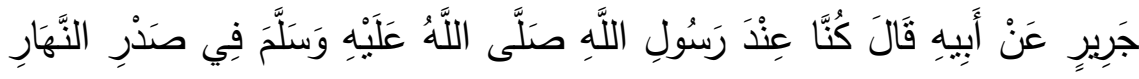

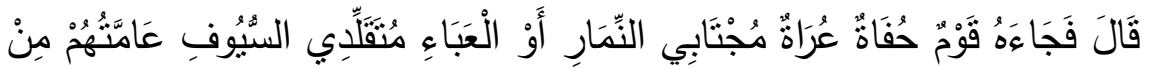

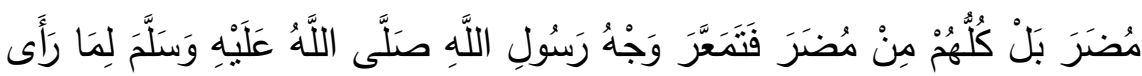

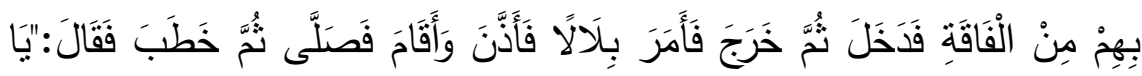

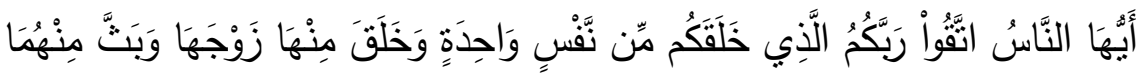

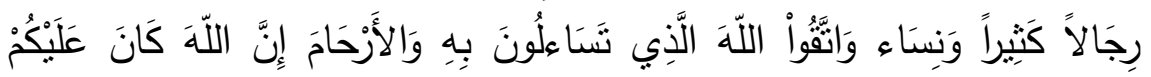

.11 (1) - (1) - سورة آل عمران الآية (1) - (1)

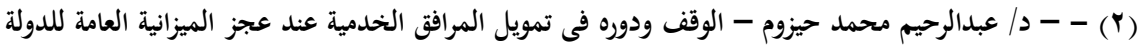

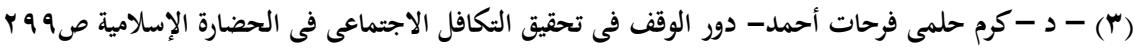

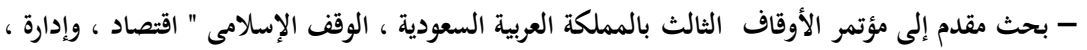

وبناء حضارة ". 


\section{الوقف مقاصده وطرق استثماره}

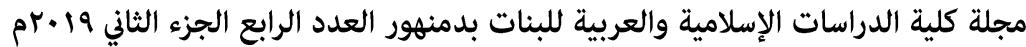

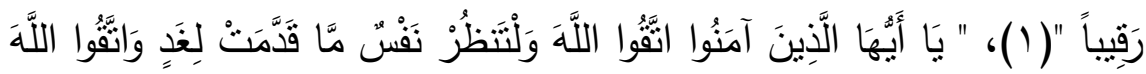

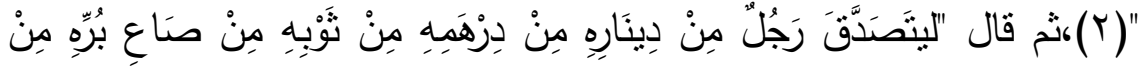

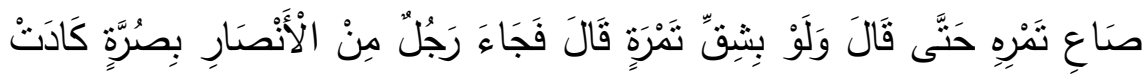

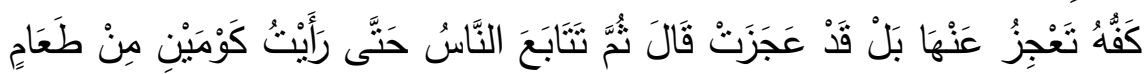

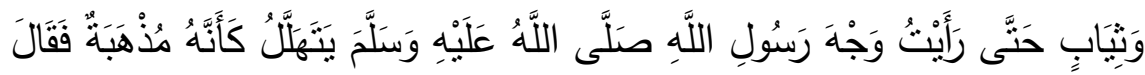

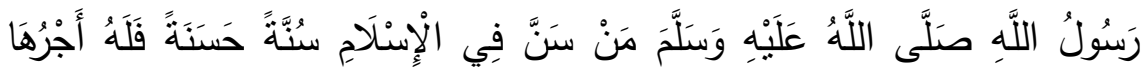

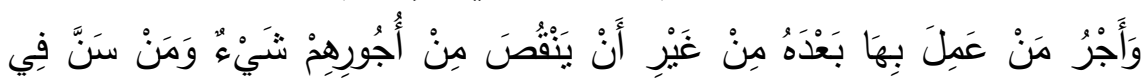

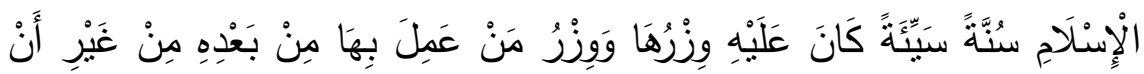

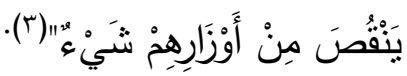

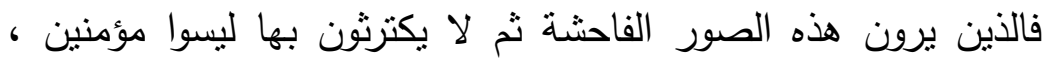
فبين البثر عامة رحم يجب أن توصل ، وألا تمزقها الفاقة ، وهذا الكلام البليغ من صاحب الرسالة دعوة إلى التتافس فى الخير والتسابق فى افتناح

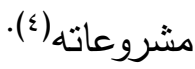

$$
\begin{aligned}
& \text { (1). سورة النساء ، الآية رقم } 1 .
\end{aligned}
$$

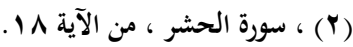

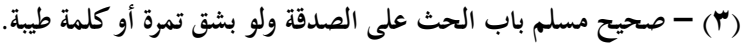

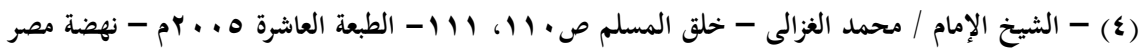

للطباعة والنشر والتوزيع. 


\section{الوقف مقاصده وطرق استثماره}

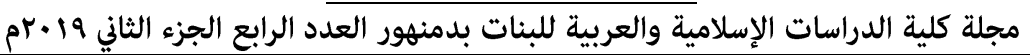

\section{المبحث الثانى}

\section{مقاصد الوقف}

قام الوقف بدور كبير في الحفاظ على المقاصد الثرعية عبر التاربخ الإسـانمىى

فالعلاقة وطيدة بين إنشاء المساجد في الإسـام ونظام الوقف ؛ فالمسجد ليس دارا أو مكانا للعبادة فقط ، وإنما هو منطلق الدعوة إلى دين الله بالحكمة والموعظة الحسنة ، لم يقوم به من تثقيف وتتوير ، ونشر الوعى الدينى السليم

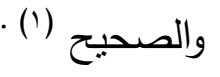

فالاوقاف قامت بدور عظيم في تدعيم المساجد لتتهض بدورها في أداء رسالتها ، بل لم يقف دور الوقف عند هذا الحد ، بل أدى الوقف دوره في تعظيم الثعور الدينى من خلال الحفاظ على هذه المؤسسات التى ملئت بطلاب العلم والخطباء والفقهاء ، والمدرسين الذين يقومون بالعملية التعليمية ، بل كان للفقراء حظا من هذه الأوقاف من خلال ما يصرف عليهم من الأوقاف، فالأوقاف تعد من أهم العوامل إن لم تكن أهمها على الإطلاق التى هذه ساعدت المساجد في القيام بمهمتها في أداء رسالتها، لكن كيف ذلك ؟ تمنل هذا الدور في دفع مرتبات العاملين فيها ؛ حيث كانت هذه الأوقاف تكفل لعدد كبير من الدعاة والمصلحين ، ورواد التجديد ، وحراس العقيدة العيش الكريم ، والاستقرار النفسى ، وهدوء البال ، وراحة الضمير ؛ ليؤدوا رسالتهم الدعوية على الوجه المطلوب ، دون خوف أو وجل من قطع الرزق ، أو المرتب من الدولة (r) . بل توفير الماء العذب للثرب والاستعمال الثخصي ، وإضاءة المساجد بالسرج والقناديل، وفرش المساجد من حصر وبسط ، بل وفرت الأوقاف للمساجد أدوات النظافة (r) .

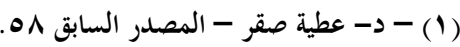

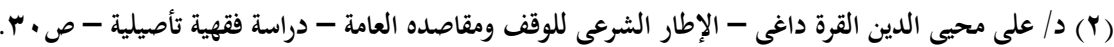

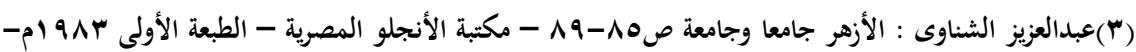




\section{الوقف مقاصده وطرق استثماره}

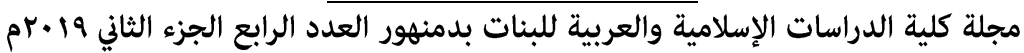

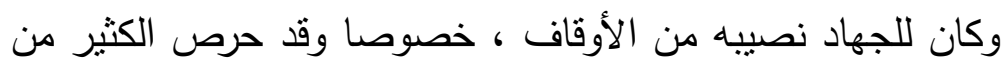

المسلمين على الوقف عليه ، لاسيما في الفترات العصيبة من تاربخ دولة

الإسلام حين واجهت أعدائها ، وقد تعددت أثكال هذا الوقف من :-

أ- أوقاف الأسلحة للإنفاق أدوات الحرب من السيوف والنبال والخيول (1) r - أوقاف الثغور لتعمير القلاع والأسوار حول المدن والأبراج لحماية المدن

الإسـلامية من الأعداء (r)

r- أوقاف تجهيز الجيوش - فتخصص أوقاف خاصة للجيش المحارب حين تعجز الدولة عن تلبية احتياجات الأفراد وتوفير عدة الحرب اللازمة لهم(r) كما قام الوقف بدور كبير فى تحقيق التكامل الاجتماعى بين أفراد المجتمع ، وفئاته المنتوعة ، من خلال رعاية الفقراء ، والضعفاء ، وذوى الحاجة ، بما يضمن لهم مستوى معيثى لائق (؟) . وتحقق هذا الدور بما يوفره الوقف من مأكل ومشرب ومسكن وملبس للمحتاجين ؛ فقد أقدم الكثير من المسلمين على وقف أموالهم لهذا الغرض ، وكان الوقف لهذا الغرض يتتوع إما الى :ו- وقف دائم فيقدم للفقراء كل يوم طعام •

Y- أو يقتصر على بعض الثهور والأيام كثهر رمضان ويومى العيد .

ب- أو شراء مواد غذائية توزع على الفقراء والمحتاجين والأيتام والأرامل (ه). ومن أروع الأوقاف في هذا المضمار ماكان يوقفه الواقفون من أسبلة ( السبل ، السقايا) لتوفير ماء الثرب لعابرى السبيل ،والمحتاجين ، وقد انتشر هذا النوع في العالم الإسلامهى من مشرقه إلى مغربه ،وكان هذا الأمر منتشرا بصورة ملحوظة في مدينة القاهرة وحرص الأمراء والسلاطين بل الميسوربين

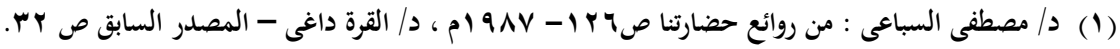

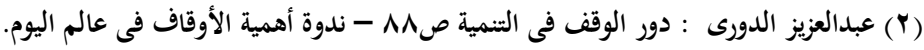

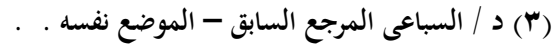

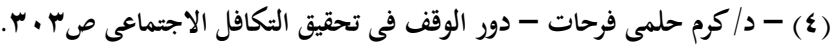

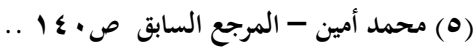




\section{الوقف مقاصده وطرق استثماره}

مجلة كلية الدراسات الإسلامية والعربية للبنات بدمنهور العدد الرابع الجزء الثاني 19 •rم

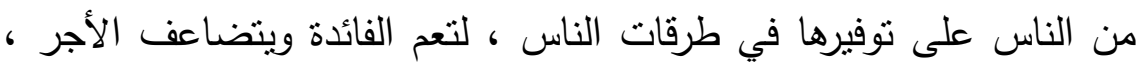

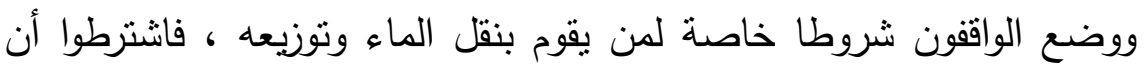
يكون رجلا ثقة أمينا جميلا نظيف الثياب ، سليم البدن خال من العاهات

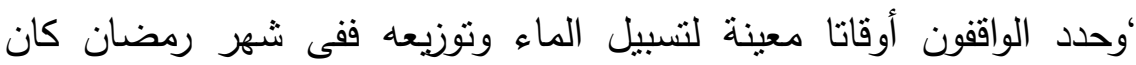
تسبييل الماء يمتد من غروب الثمس إلى ما بعد صلاة التراويح ، وفي غير رمضانت يستمر تسبييل الماء من شروق الثمس إلى غروبها ، بل ربما امتذ

إلى أن يأوى الناس إلى مساكنهم ويخلدون للراحة (1).

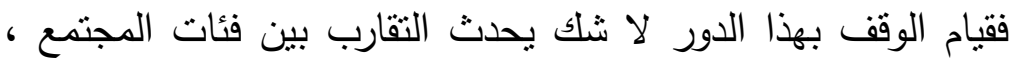

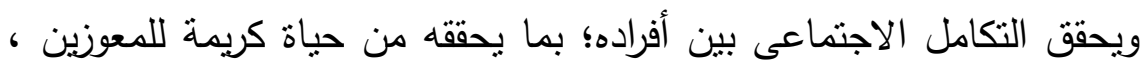

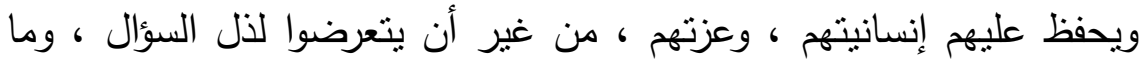

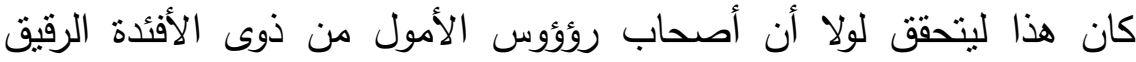
سخروا جزء من أموالهم لهذا المقصد النبيل(كان. الوقف على دور الرعاية الصحية

غصت حواضر العالم الإسلامى بالمستشفيات ، وحبست عليها

الأوقاف ، بل جهزت هذه المستتفيات بوسائل الترفيه والتسلية عن المرضى ، بالئل

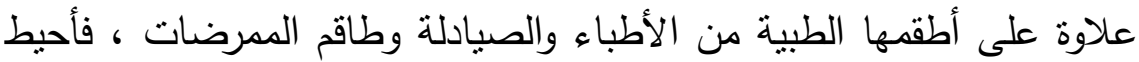

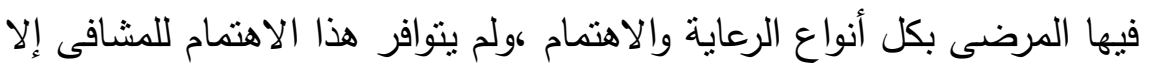

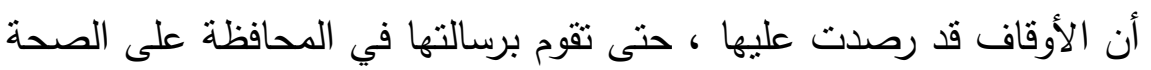

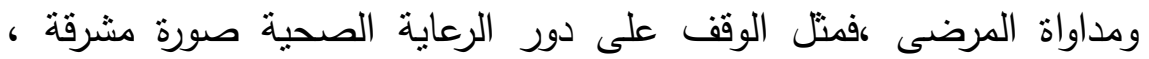

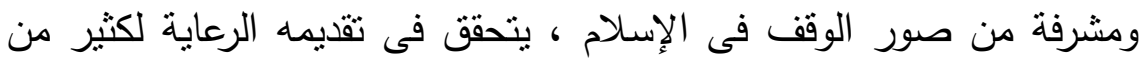

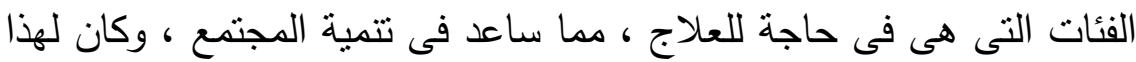
الوقف أثره الطيب في تقدم الطب وقطعه شوطا بعيدا بسبب ما توفر للأطباء

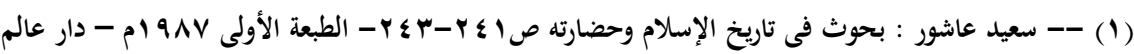

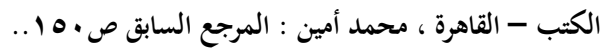

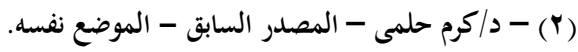




\section{الوقف مقاصده وطرق استثماره}

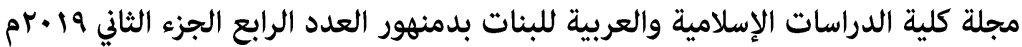

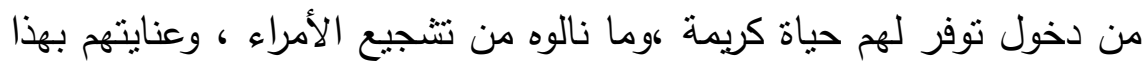

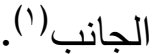

بل بلغت المستشفيات من دقة التتظيم وروعته مبلغا عظيما ، فقست

إلى أقسام تبعا لنوع كل مرض(فهذا للرمد ، والبعض للجراحة ، والآخر للأمراض العقلية ، وأخرى للعجزة ) وخصصت فاعلى لبعل مجهزة بالأدوات الطبية

، ووضعت نظما غذائية للمرضى ، وخصصت قاعات لتلقى التعليم الطبى • فالمستشفيات في نظامها لم تقل عن النظم الحديثة في الإدارة من حيث تتاوب الأطباء ، والمرور على المرضى ، والاستشارات الطبية المتخصصة ،

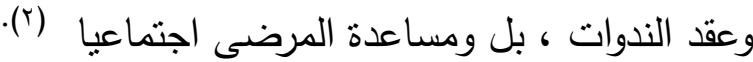

وكان المستشفى يقسم إلى قسمين منفصلين يخصص أحدهما للأكور

والأخر للإناث ، ويخصص لكل قسم طاقم منكامل من الخدم والفراشين

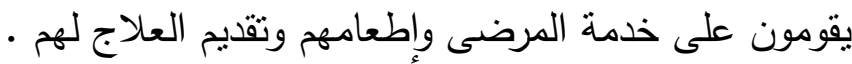

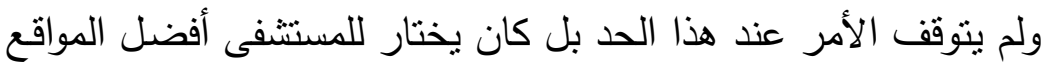

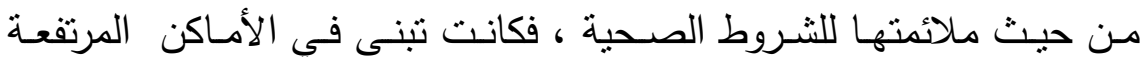

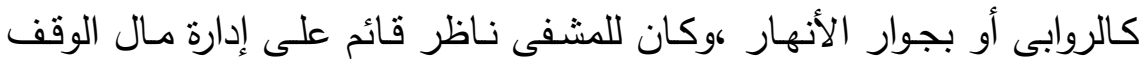

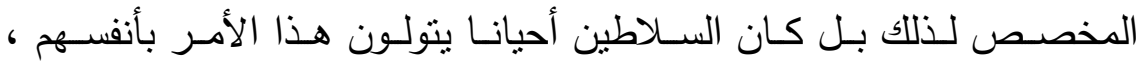

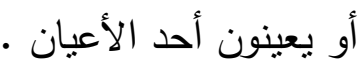

ولم تكن وظيفة المستشفى قاصرة على المدواة والعلاج ، بل شملت تدريس المناهج الطبية ، وملازمة الطلاب لأساتنتهم وعقد المناقتنات الطبية في القاعات الخاصة والمجهزة بالكتب والألات ، بل كان بعض كبار الأطباء

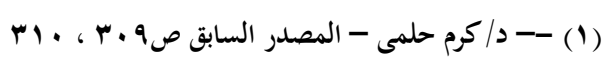

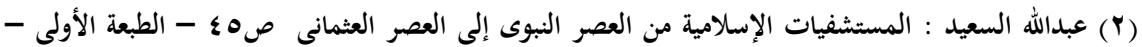

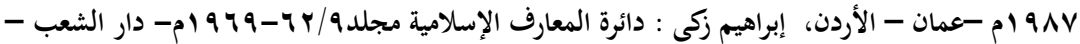

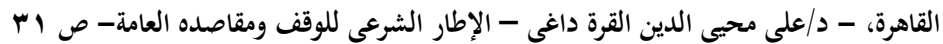




\section{الوقف هقاصده وطرق استثماره}

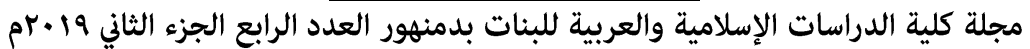

وشيوخه بعقدون مجالس خاصة لتدريس الطلاب مهنة الطب وهذا المجلس قد

يكون في مدارس أعدت لذللك أو في بيوتهم (1).

دور الوقف فى إنشاء دور التعليم والتثقيف اعتي

يعد العقل من أعظم المقاصد وأجلها لبناء الأنسان ، القادر على تحمل

المسئولية والمساهمة في بناء مجتمعه وخدمته ومن المحافظة على العقل تتويره بالعلم النافع ، والتقافة الأصيلة ، ولا شك أن الوقف لعب دورا كبيرا في هذا المجال من خلال مساهمته وقيامه بدور رئيسى في نشر دور التعليم التى ساهمت وما زالت بدور كبير فى تحصين الناشئة وصيانة عقولهم من الأفكار الدخيلة ، والمناهج المنحرفة ، لذا اهتم أهل اليسار من المسلمين بتخصيص أوقاف خيرية ؛ يصرف ريعها فى دعم فنون العلم والمعرفة ، وتأهيل العلماء والمصلحين الذين يقومون بمهمة نشر العلوم الثرعية ، التى تصان بها عقول الأمة من الأفكار والمناهج التى لا تتفق والمنظور الإسلامى (r). هذه الدور الذى قام به الوقف ساهم بدور كبير فى نشر التعليم والتقدم العلمى في التاريخ الإسلامى وتعددت أوقاف التعليم من :إنشاء المساجد ودورها التثقيفى والتعليمى

تعد المساجد من أهم المؤسسات فى المجتمع المسلم ، ولذا اهتم المسلمون بها ، وأولوها عنايتهم ، ورعايتهم ؛ لما لها من تأثير بالغ فى توجيه المجنمع ؛ فقى المساجد بدأ المسلمون يتعلمون أبجديات القراءة والكتابة وتعلم المعارف الإسلامية ، فأصبح التعليم الدينى يعمل على تحقيق أهداف الإسلام في تتشئة أبنائه على قيمه ومبادئه ومنله العليا ، بل ويزود الإنسان بعقيدة تساعده على فهم الكون المحيط به وبيصره بغايته ومصيره في هذه الحياة وهدفه فيها - ميها

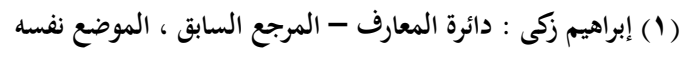

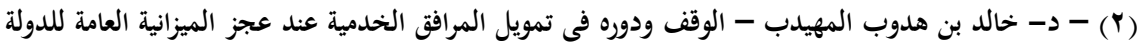

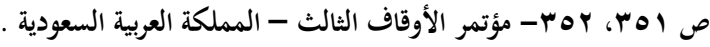




\section{الوقف مقاصده وطرق استثماره}

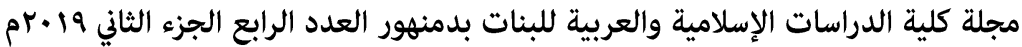

فالتعليم الدينى بوثق صلة الإنسان بكتاب ربه ، وسنة رسوله -صلى

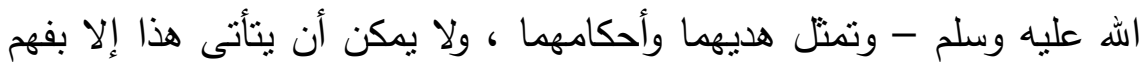

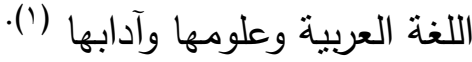

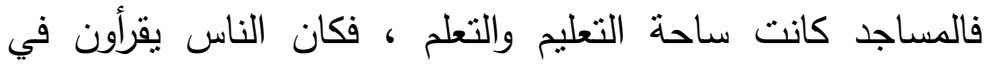

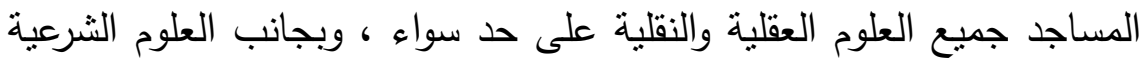
واللغوية كانت تدرس علوم الفلك والهيئة والطب والهندسة والمنطق ،وبجانب

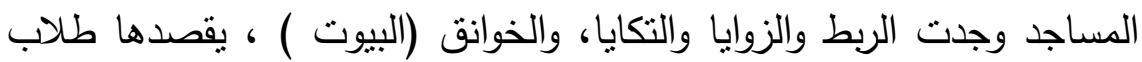

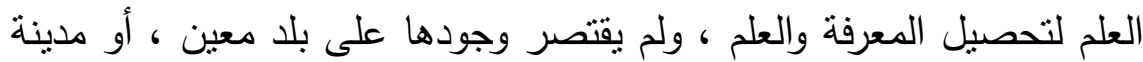

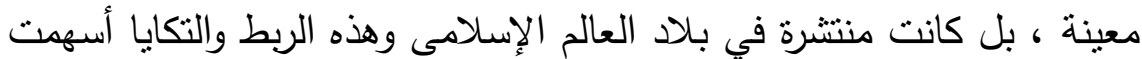

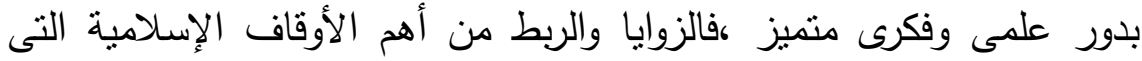
ساهت بشكل كبير فى انتشار العلم ، ورعاية مرتاديها من الطلاب الفقراء الذين لم تتيسر لهم سبل الحياة الرغدة ، فكانت توفر لهم الغذاء ، والسكن

والتعليم (r).

وشهد التاريخ الإسلامى تجربة فريدة من نوعها قام بها الوقف في مجال

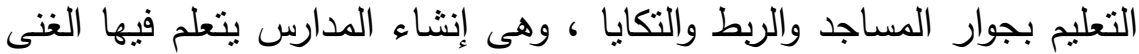
والفقير ، والصغير والكبير ، بل امتدت المخصصات الوقفية إلى إنشاء مدارس واس التهاء متخصصة لتدريس الفقه والطب والإدارة ، فالمدارس الوقفية قامت بدور كبير

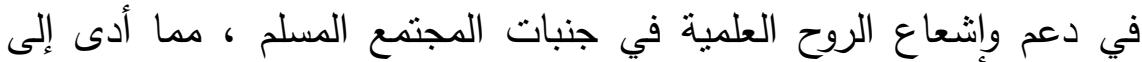
انتشارها ، وأصبحت سمة بارزة للمجتمع المسلم (r).

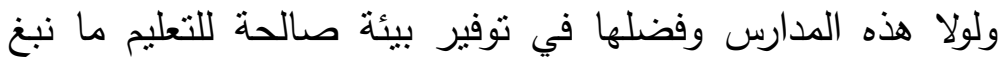

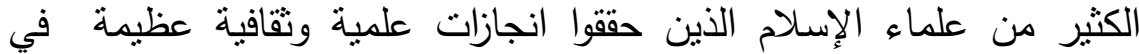

(1) محمود رشدى خاطر : الاتجاهات الحديث فى تعليم اللغة العربية والتربية الدينية ص.9 ץ- ع 9 الم-

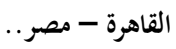

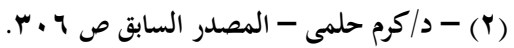

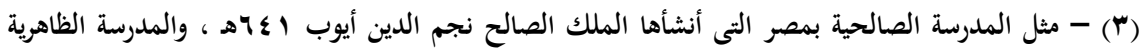

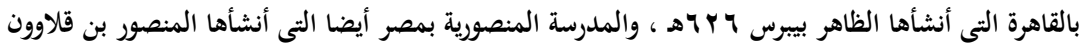

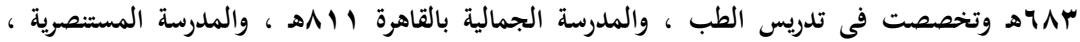

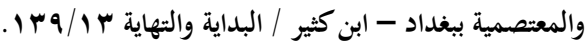




\section{الوقف هقاصده وطرق استثماره}

مجلة كلية الدراسات الإسلامية والعربية للبنات بدمنهور العدد الرابع الجزء الثاني 19 •rمأماره

التاربخ ، ولعل خير شاهد على ذلك الإمام الغزالى وأخيه أبو الفتوح أحمد ، فقد نشآ في المدرسة الوققية بعد وفاة والديها ، ونفاد المال المخصص لرعايتهما ،

فالتجائهما إلى هذه المدرسة ضمنا لما متابعة العلم وتحصبله (1). فالأوقاف الخاصة بالمدارس ارتقت بالتعليم ، وساهمت فى إرساء دعائمه ، وإثاعة ثقافة واسعة فى المجتمع المسلم ، وتوفير مصادر متتوعة للتعلم مكنت لغير القادرين من المبدعين فى التعلم ، والوصول إلى أرقى مراتب العلم والثقافة فى مختلف العلوم (؟). وساهمت المكتبات الوقفية بدور كبير في الحفاظ على العقلية الإسلامية وقد سبقت المكتبات الوققية في وجودها المدارس ، وتعددت أسماء المكتبات (خزانة الكتب - بيت الكتب - دار العلم ) وكانت هذه المكتبات إما خاصة يمتلكها أفراد لحاجاتهم الثخصية ، أو المكتبات الملحقة بالمساجد 6 والربط أو مكتبات الدولة التى ينثئها الأمير أو الخليفة ، أو المكتبات الملحقة

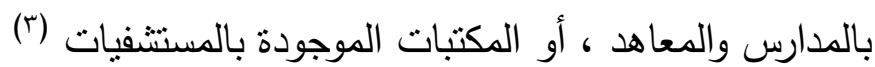

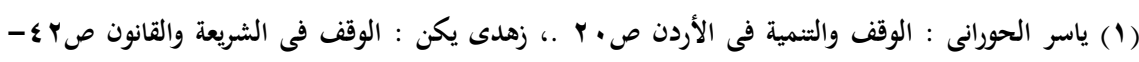

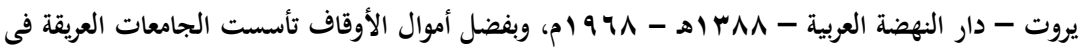

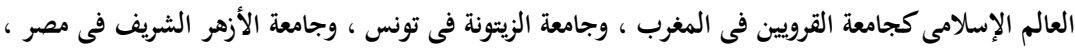

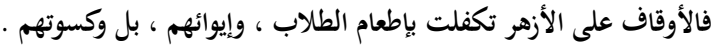

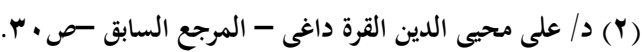

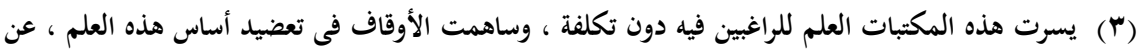

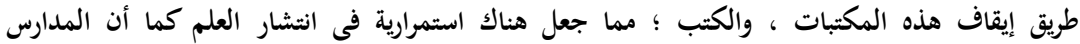

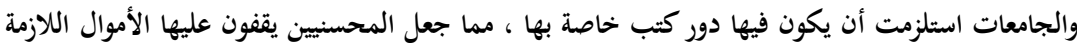

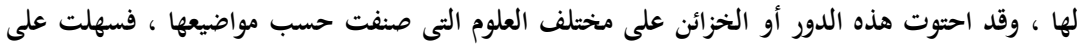

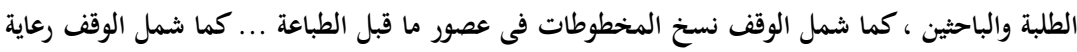

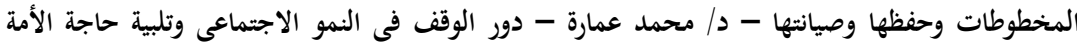

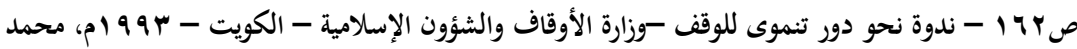

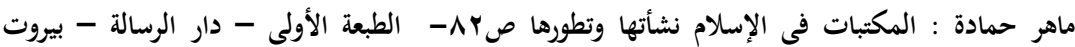

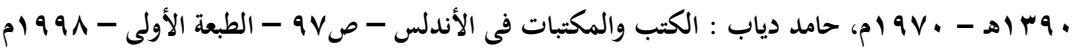

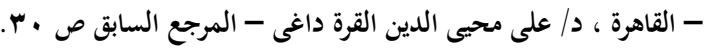




\section{الوقف مقاصده وطرق استثماره}

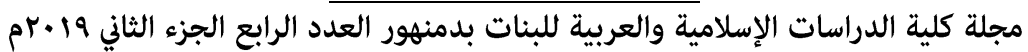

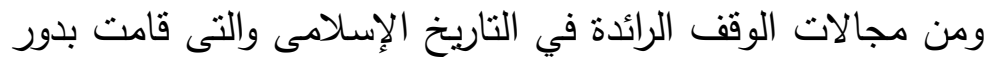

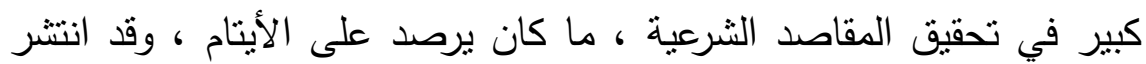

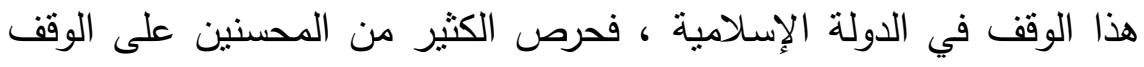
على الأيتام وتعليمهم وكسوتهم ، وفي هذا تحقيق لغرض الإسلام من الاهنمام

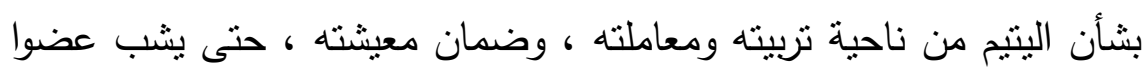

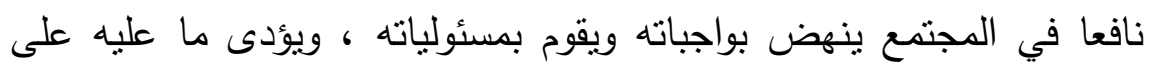

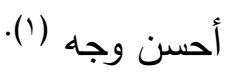

يقول الدكتور الكبسي " ... بالوقف الذى يحفظ لكثير من الجهات

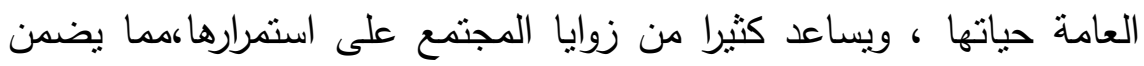

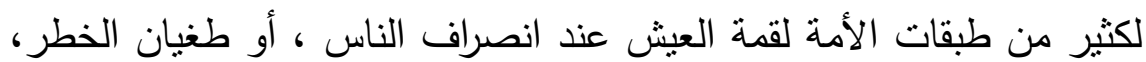

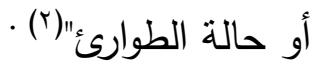

ومن عظمة الثريعة الغراء كفالتها لمن ينضوى تحت لوائها الحياة

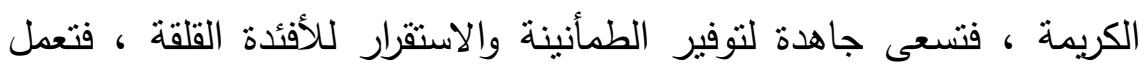
على سد حاجاتهم ، فرصدت الأوقاف لتزويج الفتيات الفقيرات ، وللنساء

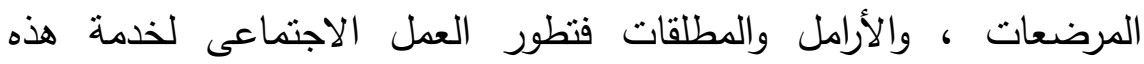
الشرائح، وأنشئت مؤسسات اجتماعية ، ورباطات في مختلف أنحاء الدولة الإسلامية لخدمة هذه الثرائح . _ولم يقتصر دور الوقف على ما أسلفناه من تحقيق المقاصد الضرورية،

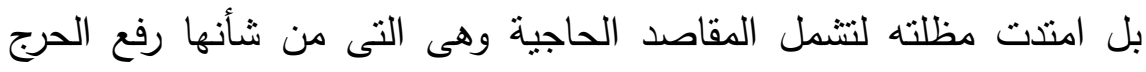
والمشقة والضيق والتتوسعة على الناس ،فقام الوقف بإنشاء الدور التى ينزل فيها المسافرون من التجار ( الخان ) وتحفظ فيها أمتعتهم وبضائعهم ،وهذه ولثهاء

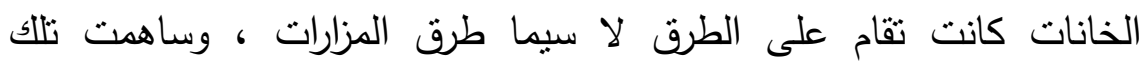

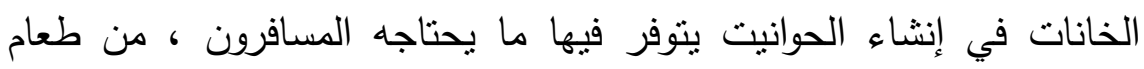

(1) عبدالله علوان : النكافل الاجتماعى فى الإسلام ص آ - الطبعة الخامسة - دار السلام - r. بـ اهـ -

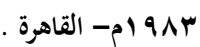

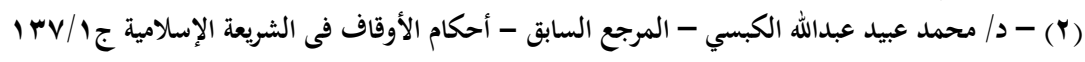




\section{الوقف مقاصده وطرق استثماره}

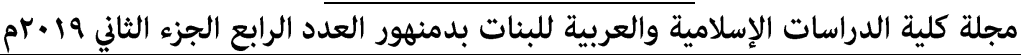

وغيره ،بل كان الخان بمثابة مدرسة تعلم فيها القراءة والكتابة وحفظ القرآن

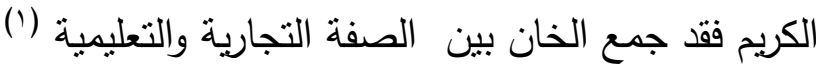

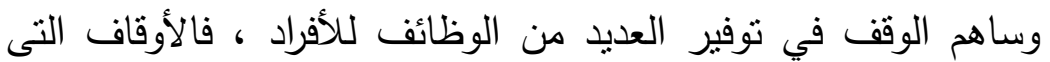

خصصت لعمارة المساجد ، وفرت العديد من الوظائف بجانب عمارة المسجد

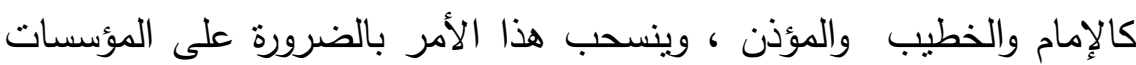

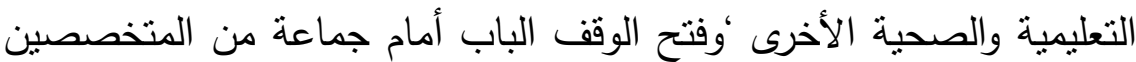
في شتى الأعمال فالأوقاف المخصصة للإطعام والإيواء والتعليم والعلاج الطبى تحتاج إلى أفراد متخصصين في توفير الغذاء وتدبير المسكن وآخرين

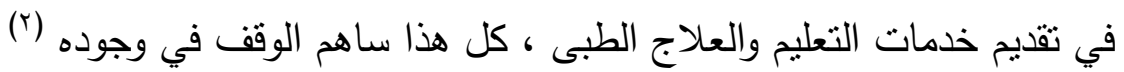
ومن المقاصد التى ساهم فيها الوقف بحظ وافر ، تخفيف الأعباء المالية وهلية للدولة ، من خلال الوقف على مشاريع البنية الأساسية ، مما يوفر على الدولة كثير من الموارد مما يساهم في حفظ الديون وتراجع العجز في الميزانية ، مما ساهم في رفع معدلات النمو الاقتصادى وتحقيق التتمية (ץ). دور الوقف في الحد من مشكلة البطالة

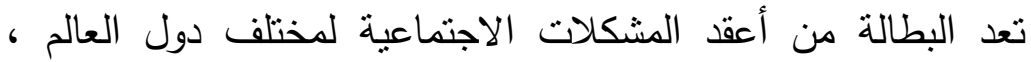
ويمكن للوقف أن يكون أداة فعالة لعلاج مظاهر العوز والاحتياج فى المجتمع الإسلامى ؛ لتحقيق الاستقرار وحماية المجتمع من الاضطرابات الاجتماعية ،

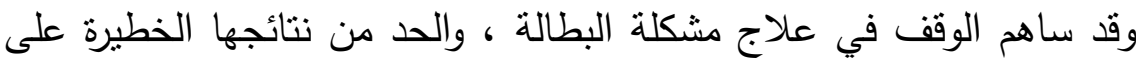
المجتمع من خلال إعداد الأيدى العاملة في مختلف الأعمال كما لئه

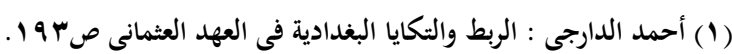

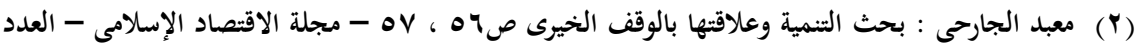
1V مكانة الوقف وأثره فى الدعوة والتنمية - مكة المكرمة.

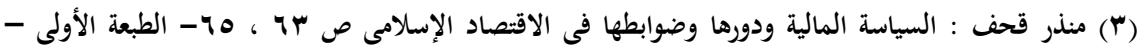

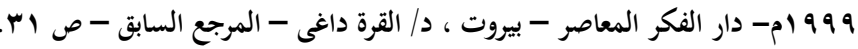




\section{الوقف مقاصده وطرق استثماره}

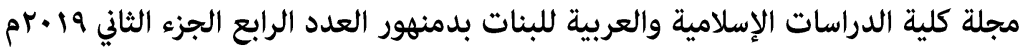

وكيفا،وتحسين نوعية قوة العمل بما يوفره من فرص تعلم المهن والمهارات ،

ورفع الكفاعة المهنية ، والقدوة الإنتاجية للعامل (1).

فالأوقاف لها دور عظيم فى الإنتاج والتشغيل والقضاء على البطالة ،

والتضخم ، ولها دور أكبر فى التتمية البثرية ، تتمية الإنسان بصورة مباشرة ، أو غير مباشرة ، وقد تغيا المشرع الإسلامى الحنيف بنظام الوقف تتمية رأس

المال الإنسانى (r) (r)

فأثز الأوقاف المباشر يكمن فى نشغيل مئات الألآف فى مختلف المؤسسات التعليمبة والصحية ، والاجتماعية ، بل تكونت مجموعة من الوظائف لم تكن موجودة من قبل منل القيم والناظر ، والمدرس ، والمعيد ، والفقيه ، والكاتب ، والجابى ، وغيرهم ،

فالوقف إذا وظف فى مشروعات اقتصادية سيكون له أثز مباشر على

$$
\text { الزيادة فى فرص العمل ، ومن هذه الفرص :- }
$$

1 - تتمية النشاطات المرتبطة بالزراعة ، خصوصا فى المناطق الريفية ، الأشد احتياجا ، وامداد هذه الأماكن بما تحتاجه من مرافق اجتماعية لسد • ماجة السكان

ب - تتمية الصناعات الصغيرة ، والمتوسطة ، والصناعات التقليدية ، وهذا ما قامت به أموال الأوقاف فى الماضى من تمويل بعض الصناعات الحيوية، كصناعة الأسلحة والسفن (r) .

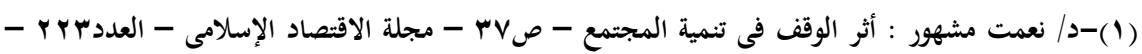

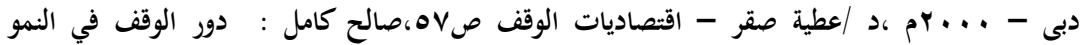

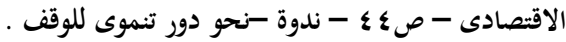

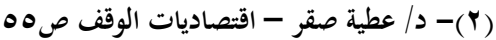

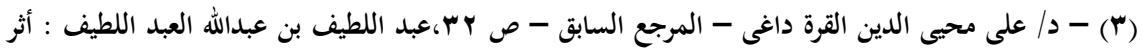

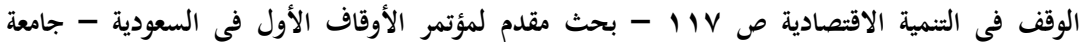

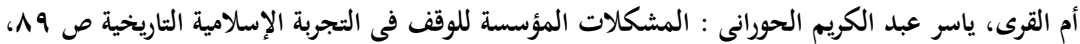

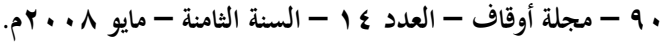




\section{الوقف مقاصده وطرق استثماره}

مجلة كلية الدراسات الإسلامية والعربية للبنات بدمنهور العدد الرابع الجزء الثاني 19 •rم

ج - إنشاء صناديق وققية لعلاج مشكلة البطالة ، ينت من خلالها إصدار

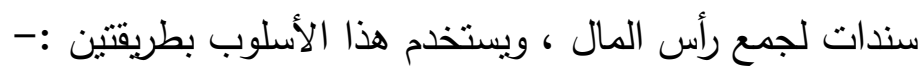

1- إقراض العاطلين عن العمل على سبيل القرض الحسن ، بما بمكن

المحتاجين من كسب سبل العيش •

r- إنشاء صناديق استثمارية تقوم على مشاركة العاطلين فى المشروعات التى لـى

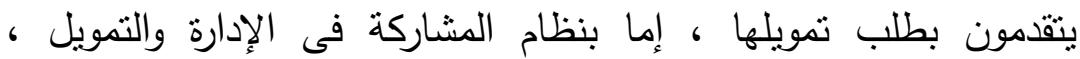

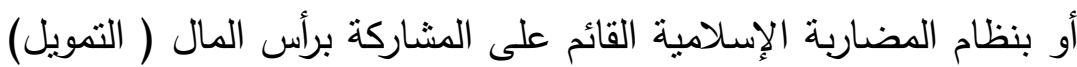

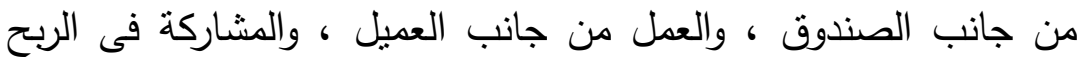

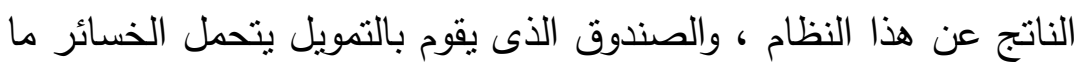

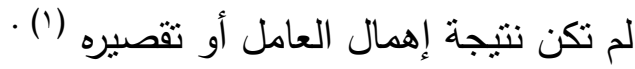

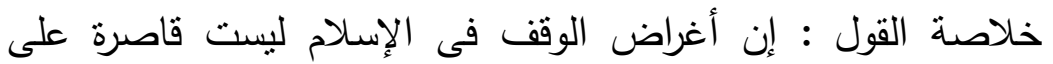

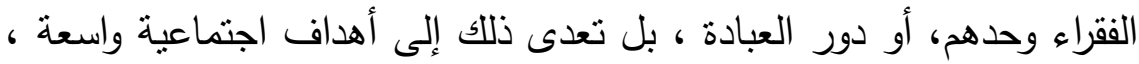

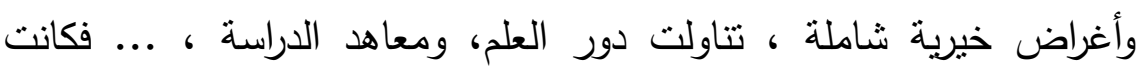
للوقف جامعات علمية ومؤسسات نشرت نورها فى الكون ، وحملت رسالة

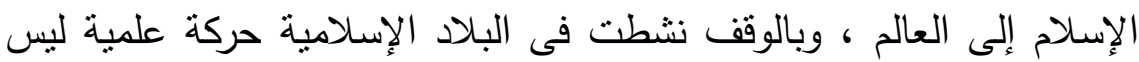

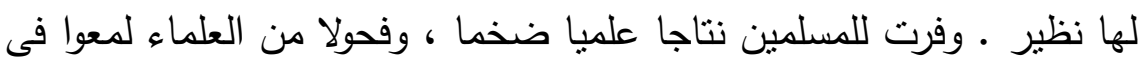

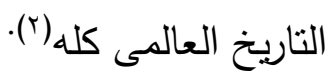

(1) - د - محمد عبد الحليم عمر - سندات الوقف - مقترح لإحياء دور الوقف فى المجتمع الإسلامى المعاصر

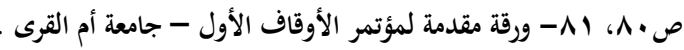

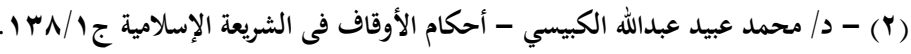


الوقف مقاصده وطرق استثماره

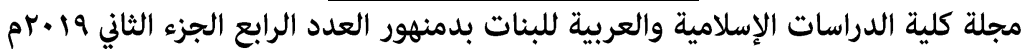

\section{المبحث الثالث}

\section{استثمار الوقف ومجالاته}

ليس هنالك طريقة واحدة تلائم كل الأموال الموقوفة ،وإنما لكل مال

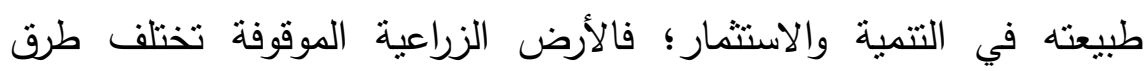
استثمارها عن المبانى ، والمال المنقول الموقوف بلا شك تختلف طرق استثماره تبعا لاختلاف أثكاله ،فضلا عن أن هناك طرق تقليدية لاستثمار الوقف ، وطرقا أخرى استجدت تبعا لمقتضيات العصر الذى نعيشه .

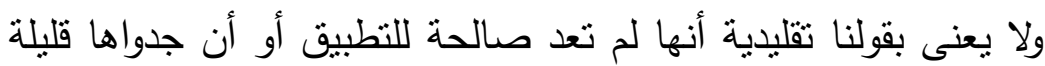

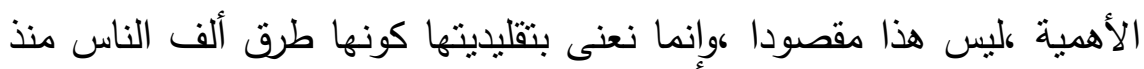

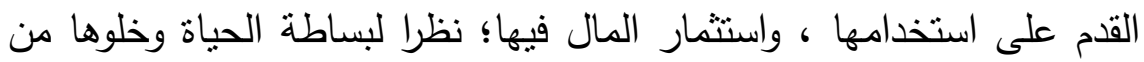
التعقيد الذى نشاهده في حياتتا . ونتناول أولا الطرق التقليدية لاستثمار مال الوقف ثم نُشتَى بالطرق

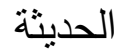
أولا : الطرق التقليدية لاستثمار مال الأوقاف تعددت هذه الطرق ما بين الإجارة ، والحكر والمضاربة ، والمزارعة والمساقاة

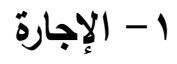

وهى أكثر الوسائل شيوعا في استثمار مال الوقف وهى محل اتفاق بين العلماء وإن اختلفوا في بعض التقصيلات والتفريعات كحق الموقوف عليهح

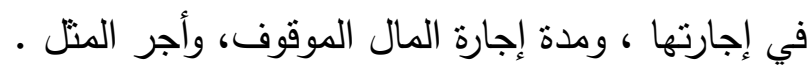

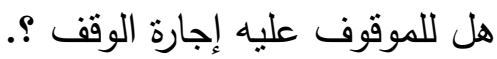

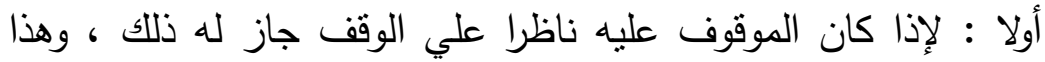

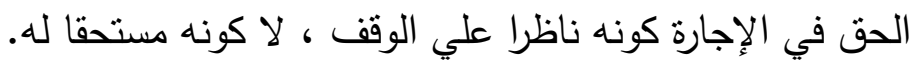

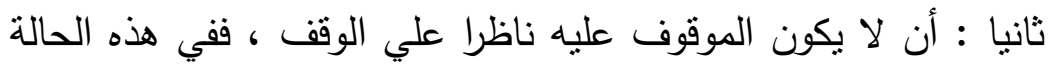

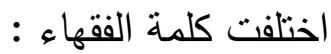




\section{الوقف هقاصده وطرق استثماره}

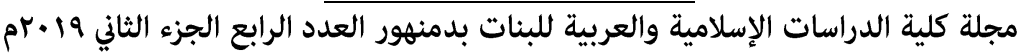

المذهب الأول: يري أنه لا حق للموقوف عليهم في إجارة الوقف ، وهو

للحنفية والثافعية(1).

واستذلوا: لأن الموقوف عليه بملك المنافع بلا بدل ، فليس له تمليكها

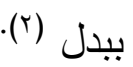

المذهب الثاني: يري أن للموقوف عليه الحق في إجارة الوقف ، وهو

للمالكية والحنابلة(ب).

-المدة في إجارة مال الوقف تباينت فيها آراء الفقهاء على التحو التالى :الرأى الأول :- يرى أن مدة الإجارة في الوقف لا يجوز أن تزبد على سنة ، وفي الأرض الزراعية سنوات ثلاثه إلا إذا اقتضت المصلحة ذلك وهو

للسادة الحنفية(؟)

وحجتهم أن الإجارة الطويلة في الوقف باطلة ؛لاحتمال تضرر مال الوقف بطول المدة ، ومن الممكن أن تؤدى طول المدة إلى إبطال الوقف ذاته،

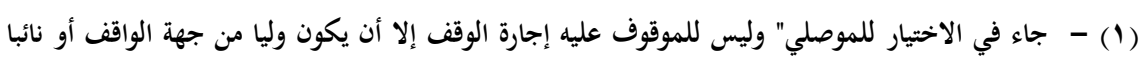

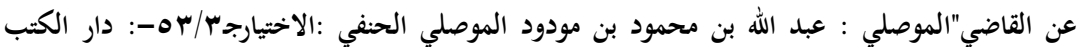

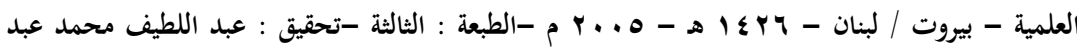

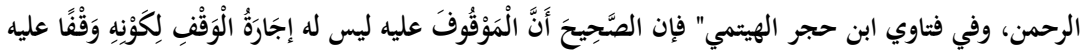

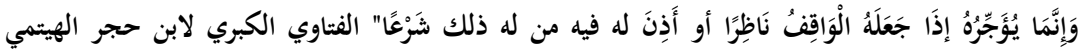

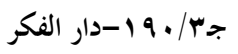

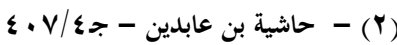

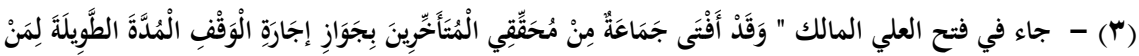

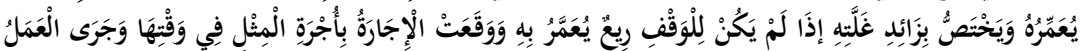

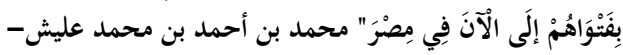

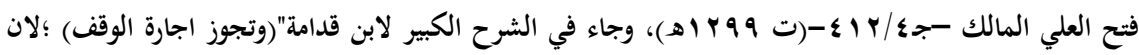

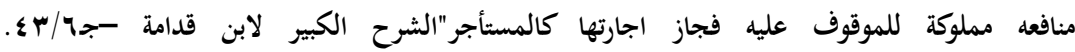

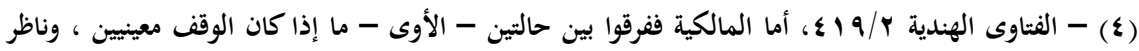

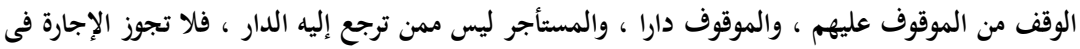

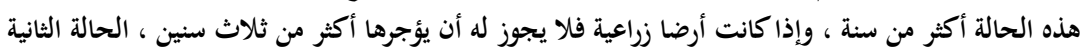

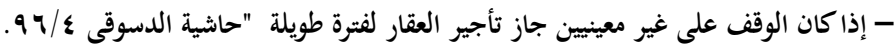




\section{الوقف مقاصده وطرق استثماره}

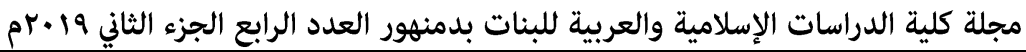

إلا إذا اقتضت المصلحة تطويل مدة الإجارة في الوقف لإعماره بتعجيل أجرته

سنين مقبلة ، فيجب أن نكون الإجارة في عقود منرادفة ومتكررة كل سنة ('). الرأى الثانى :- يرى أنه يجوز تطويل مدة الإجارة إذا كان الوقف خربا

وهو لبعض المالكية (r).

وحجتهم إن إجارة الوقف الخرب الذى تعذرت إعادته من غلته يمكن إصلاحه من كرائه ممن بعمره بالبناء ونحوه ، ويكون البناء ملكا للبانى ، ويدفع نظير الأرض حكرا (مبلغا ) للمستحقين. ب- مقدار الأجرة في الوقف :

يري جمهور الفقهاء من الحنفية والمالكية والثافعية أن العين الموقوفة

إذا أُجرت فإنها تؤجر بأجر المثل ، أو بنقصان يسير مما بتسامح فيه(r). بينما يري السادة الحنابلة صحة عقد الإجارة حتي ولو أجرت بأقل من

أجر المنل ، وحتي لو كانت الإجارة بغبن فاحش (ع). الإجارة بغبن فاحش.

يري الحنفية أن من لله حق إجارة الوقف لا يجوز لله أن يؤجره بغبن فاحش ؛ لأنه قد يموت والإجارة لا تتفسخ بموته ، فيلحق الضرر المستحقون للوقف بعده بسبب نقصان الأجرة ، أو يلحق الضرر الوقف نظرا لكونه محتاجا

للعمارة والإصلاح (0).

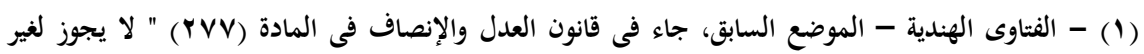

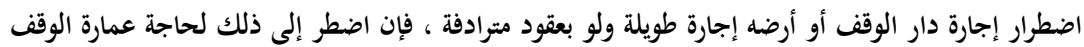

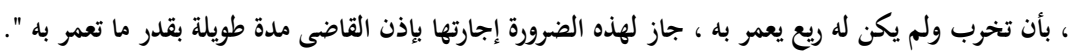

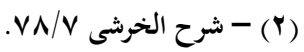

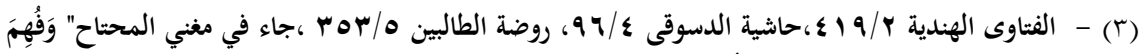

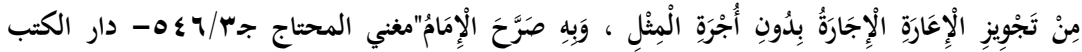

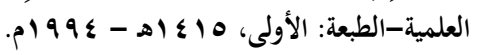

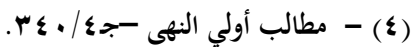

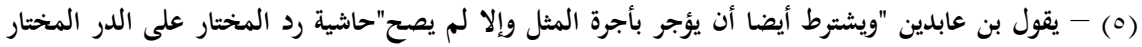

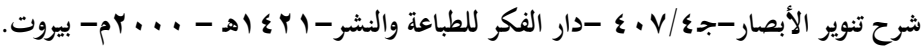




\section{الوقف مقاصده وطرق استثماره}

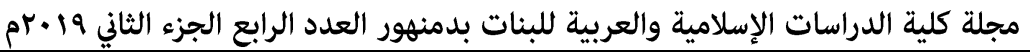

ويترتب علي الإجارة بغنن فاحش عند السادة الحنفية فساد عقد

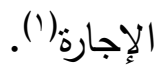

ويفرق الثافعية والحنابلة بين حالتين ، الأولي : أن يؤجر الناظر العين الموقوفة علي غيره ، وفي هذه الحالة ليس الحق في تأجيرها بأقل من أجرة

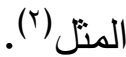

الحالة الثانية :أن تكون العين الموقوفة عليه ، فإنه يجوز له تأجيرها

$$
\text { دون أجرة المنل ، قياسا علي صحة إعارتها منه (r). }
$$

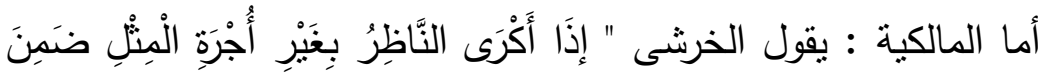

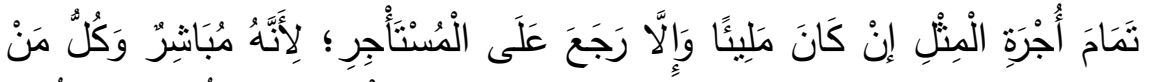

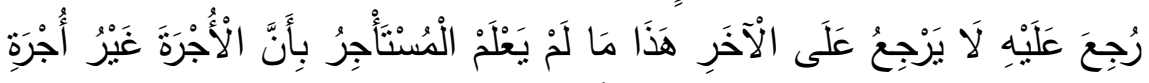

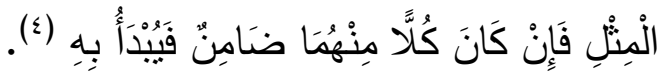

حكم إجارة الوقف إذاقت (نقصت) الأجرة أو زادت بعد إبرام عقد الإجارة. ا-إذا نقصت الأجرة أثثاء مدة الإجارة ، بسبب طارئ ما أدي لنقصانها نقصا فاحثا ، وطلب المستأجر للعين الموقوفة إنقاص الأجرة ، أو فستخ العقد

فإنه لا يجاب إلي طلبه ، وليس لناظر الوقف إقالته(ه).

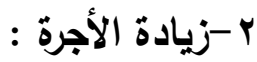

أولا : رأي الحنفية : اختلف الحنفية في حكم زيادة الأجرة بعد العقد ، وهل لها تأثير عليه بالبطلان؟.

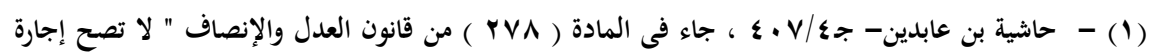

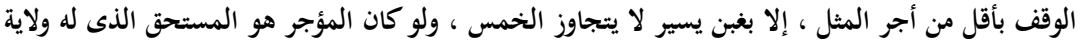

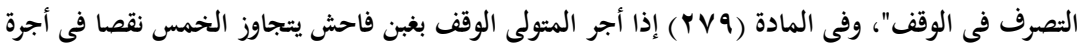

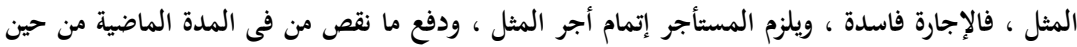

$$
\text { (Y) }
$$

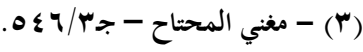

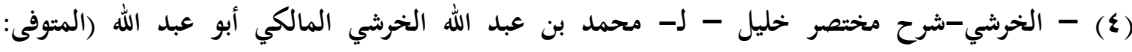

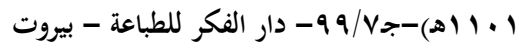

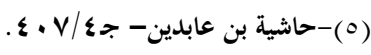




\section{الوقف مقاصده وطرق استثماره}

مجلة كلية الدراسات الإسلامية والعربية للبنات بدمنهور العدد الرابع الجزء الثاني و أبماهم

الرأي الأول: يري أن الإجارة صحيحة ولا تتفسخ بالزيادة ، حتي ولو

كانت فاحشة عن الأجر المسمي في العقد (1).

لأن المعتبر هو أجر المنت وقت العقد (؟).

الرأي الثاني: وهو الأصح عندهم ، يري أن العقد ينفسخ بالزيادة

الفاحشة في الأجرة ، وبعقد العقد مرة ثانية بالزيادة(؟).

ثانيا : رأي المالكية والحنابلة : يرون أن عقد الإجارة صحيح ما دام أنه عقد بأجر المنت عند العقد ، ولو زادث الأجرة زيادة فاحثة بعد ذلك فلا يجوز

فسخه (乏).

لأن عقد الإجارة علي العين الموقوفة أصبح لازما عن المدة المحددة في العقد ، والأجر المستحق هو الأجر المسمي في العقد ، وهو أجر المثل وقت

إبرامه ، وهذا الأجر هو الذي يلزم المستأجر (ه).

ثالثا: رأي الثافعية:بفرق السادة الثافعية بين حالثين :

الأولي : إذا أجر ناظر الوقف العين الموقوفة عليه ، فإن العقد يكون

صحيحا ولا بفسخ حتي ولو كانت الأجرة دون أجرة المثل ، كما لو أجر ملكه

المطلق (†).

الحالة الثانية: تأجير العين الموقوفة علي غيره ، ثم حدثت الزبادة في

الأجرة ، فهنا اختلف الثافعية علي أقوال ثلاثثة :

القول الأول: يري صحة عقد الإجارة، ولا تتفسخ ، وهو الأصحح عند

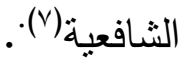

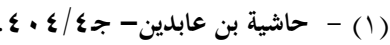

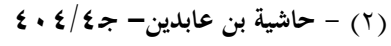

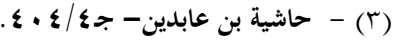

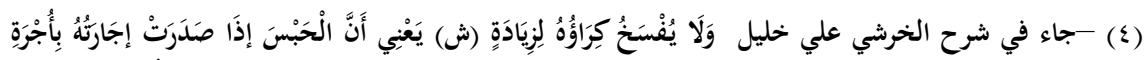

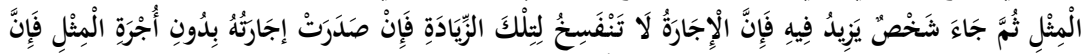

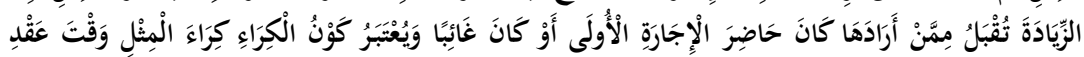

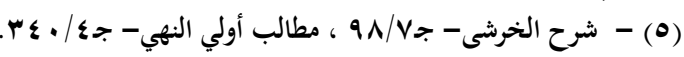

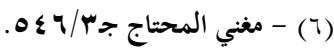

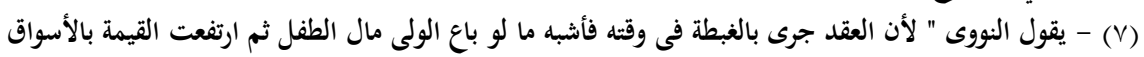

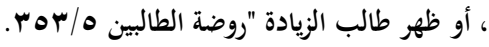




\section{الوقف هقاصده وطرق استثماره}

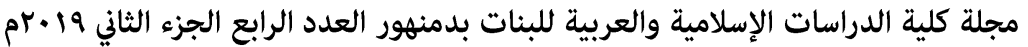

القول الثاني: يريأنه يحق لناظر الوقف فسخ عقد الإجارة ونقضه ؛

$$
\text { بسبب الزيادة. }
$$

القول الثالث: يري أن الإجارة للوقف إذا كانت سنة فأقل ، فلا تأثير للزيادة في الأجرة علي العقد ، وإن كانت مدة الإجارة أكثر من سنة فلا يجب الوفاء بعقد الإجارة)(')

\section{هل يجوز إيجار مال الوقف بأقل من سعر المثل ؟

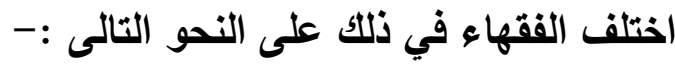

المذهب الأول:- يرى أنه لا يجوز إيجار الوقف بأقل من أجر

المثل إلا إذا اقتضت الضرورة ذلك ،فإذا كان الإيجار بغبن فاحش فلا يجوز ،

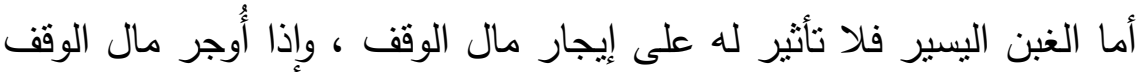

بأقل من أجره المثل جاز للقيم عليه فسخ العقد (الحنفية ، المالكية،الثافعية) (؟) والوقت المعتبر في أجره المنل هو وقت بداية عقد الإجارة للمال

الموقوف ولا عبرة بما بطرأ على الأجرة من زيادة خلال مدة العقد (r).

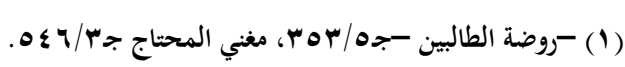

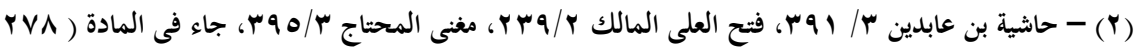

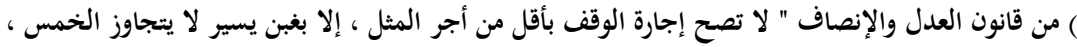

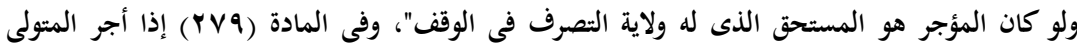

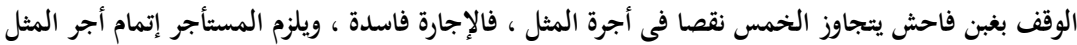

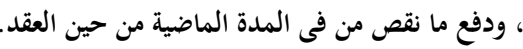

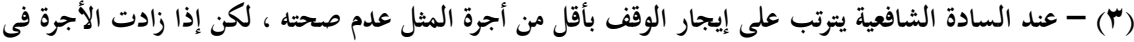

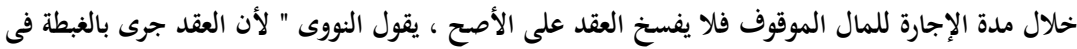

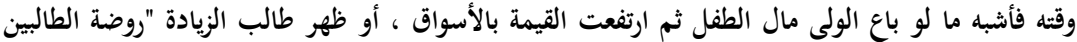

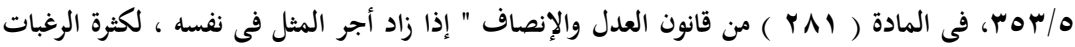

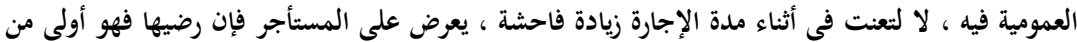

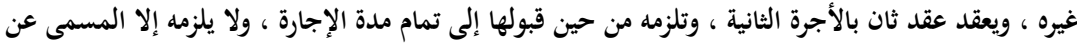

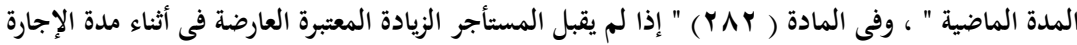

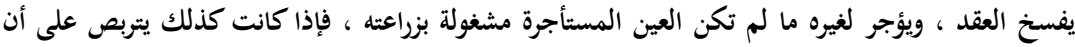

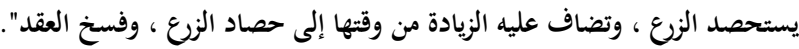




\section{الوقف مقاصده وطرق استثماره}

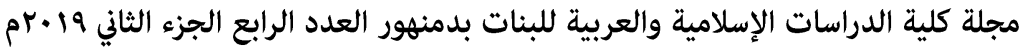

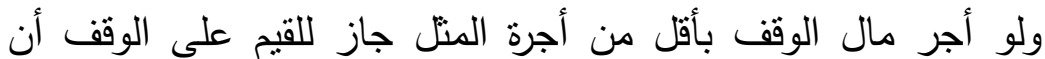

يعدل في عقد الإجارة حتى ييلغ أجر المثل ، ولون الوة كان ذلك دون رضاء

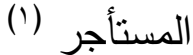

ويترتب على إجارة مال الوقف بأقل من أجرة المثل بطلان العقد وقابليته

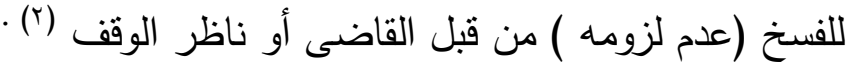

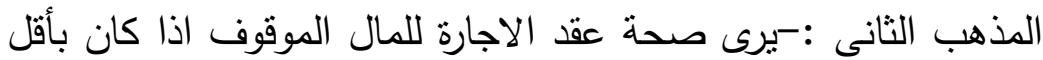

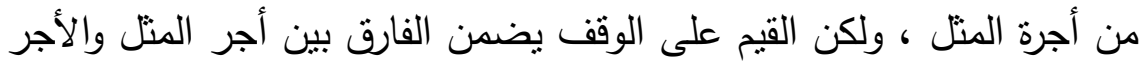

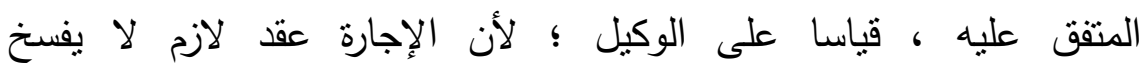

بذلك (الحنابلة) (r).

الرأى الراجح : :- هو الرأى القائل بعدم جواز إجارة الوقف بأقل من أجرة

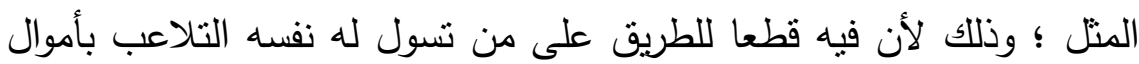

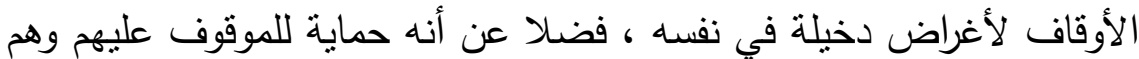

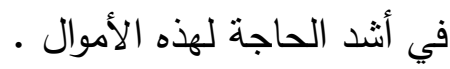
r- الدكر :- وهو عقد إجارة يقصد به استيفاء الأرض الموقوفة ، مقررة للبناء

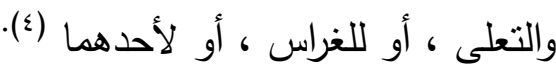
ويموجب عقد الحكر يتم الاتفاق مع ممول يقوم بعمارة ما تخرب من احنا الوقف ، وييرم معه عقد إجارة طويل الأجل.

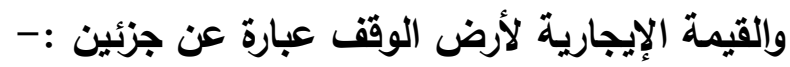

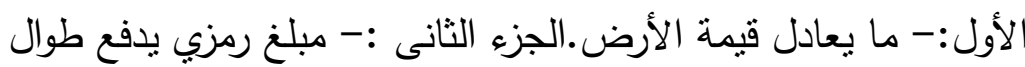

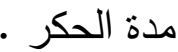
وتظل الأرض على ملكية الواقف ، أما ما تم من بناء عليها فيكون

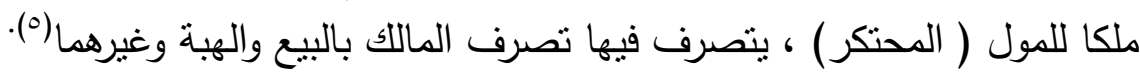

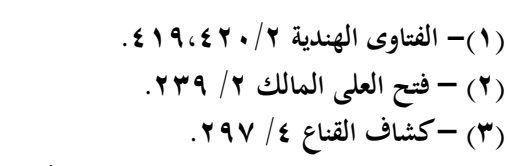
(气)

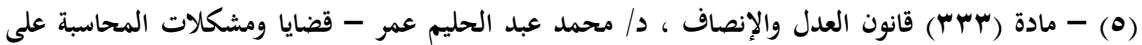

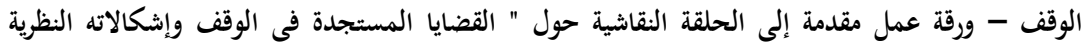

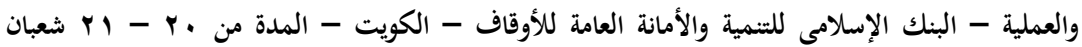




\section{الوقف مقاصده وطرق استثماره}

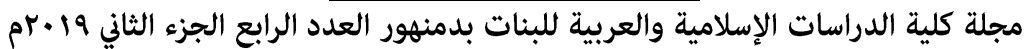

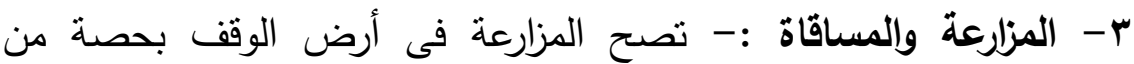

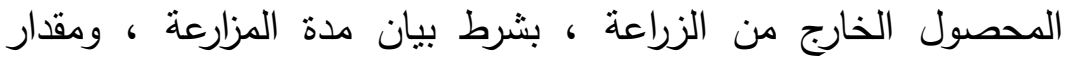

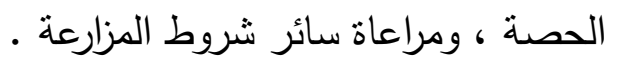

والمساقاة : هى دفع الثجر والكرم إلى من يصلحه بجزء من الثمرة ،

$$
\text { وتصح المساقاة بشروطها ... بحصة معلومة للمساقى (1). }
$$

ع - المضارية :-- وهى عقد بين طرفين أحدها رب المال "صاحبه" والآخر

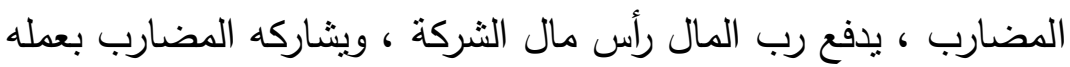

بغية استثماره وتحقيق الربح من ورائه (؟).

والمضارية من العقود المشروعة باتفاق الفقهاء (ז).

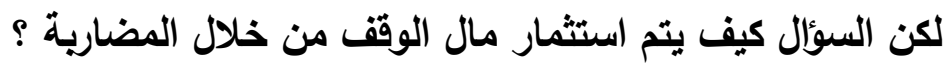

صورة استثمار مال الوقف من خلا المضاربة يتم بتقديم المال

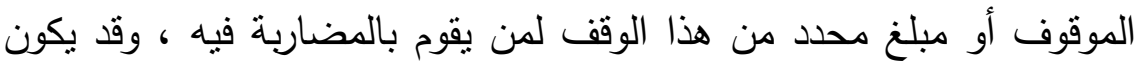

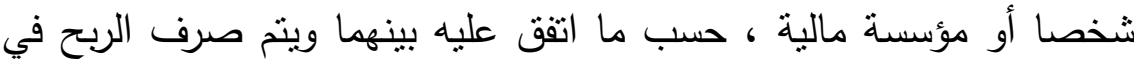

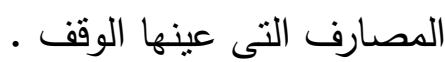

\section{والمضارية في مال الوقف لها صور ثلاث :-}

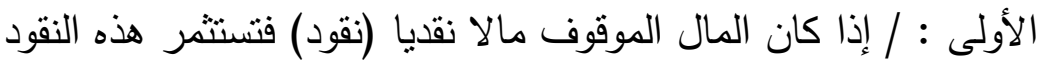

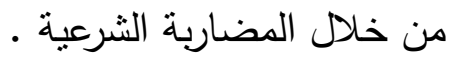
الصورة الثانية: / الفائض عن مصرف الوقف لادى إدارة الوقف ، فتدخل

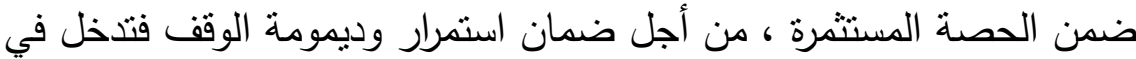

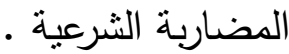
الصورة الثالثة :/ الآلات ووسائل النقل والحيوانات فيجوز إعطائها

للمضارب لنتغيلها ويكون الناتج بينهما حسب الاتفاق و (؛).

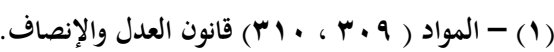

ا

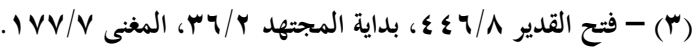

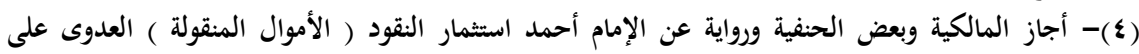

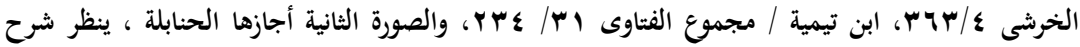




\section{الوقف مقاصده وطرق استثماره}

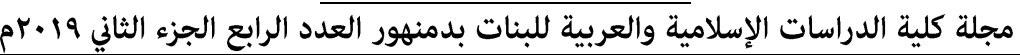

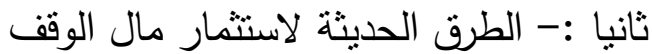

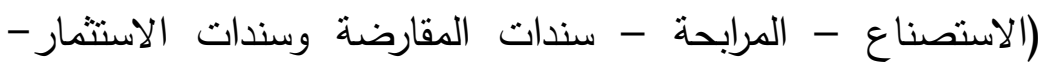

$$
\text { أولا - الاستصناعة - الصكوك) }
$$

تعريفه:في اللغة: مصدر استصنع، بمعنى طلب الصنعة ، والصناعة

حرفة ومهنة الصانع (')

وفي الاصطلاح: عقد على مبيع فى الذمة شُرِطَ فيه العمل (r).

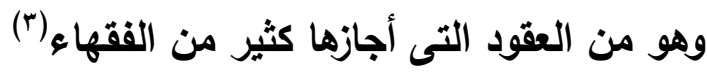

ويمكن من خلاله لإدارة الوقف الاستفادة منه في بناء مشروعات كبيرة

تعود بالنفع على الموقوف عليهم ، من خلا الاتفاق مع أحد المستثرين

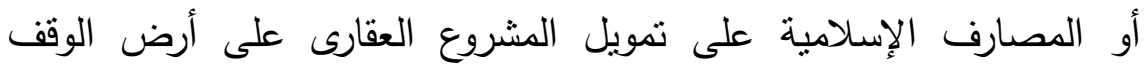

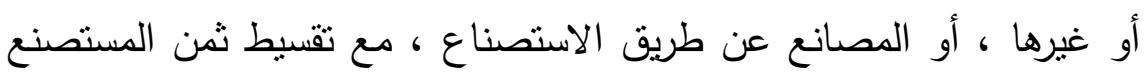

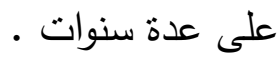

ومن مزايا عقد الاستصناع أنه لا يشترط فيه تعجيل الثمن ، بل يجوز

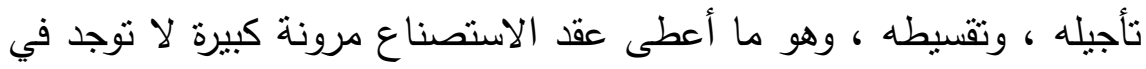
عقد السلم (£) عاجله

وعقد الاستصناع من العقود التى بحثها مجمع الفقه الإسلامى

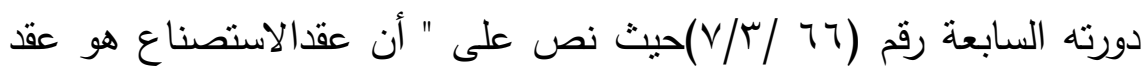
وارد على العمل والعين في الذمة - ملزم للطرفين إذا نوافرت فيه الأركان والثروط"

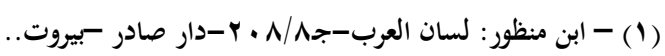

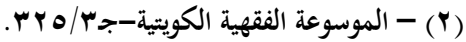

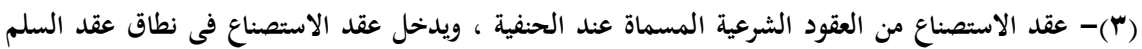

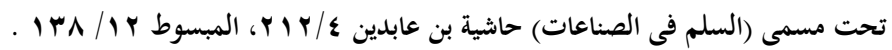

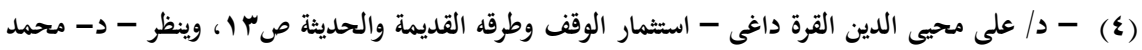

$$
\text { عبد الحليم عمر - المصدر السابق. }
$$




\section{الوقف هقاصده وطرق استثماره}

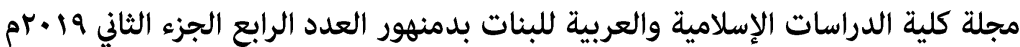

والمصارف الإسلامية تقوم بعقد الاستصناع عن طريق ما بسمى

بالاستصناع الموازى ، حيث لا تقوم بعملية البناء أو الاستصناع بنفسها وإنما بالاتفاق مع مقاولين لتتفيذ المشروع وفقا للمواصفات التى تم الاتفاق عليها

بينها وبين إدارة الوقف (1).

$$
\text { ثانيا - المرابحة }
$$

في هذه الصورة تقوم إدارة الوقف باستثمار مال الوقف عن طريق المرابحة العادية(r). وشراء ما تحتاج إلبه ، ،أو عن طريق المرابحة للآمر بالثراء (r).عن طريق المصارف الإسلامية وفقا لخطوات محددة :ا - وعد بالثراء من قبل إدارة الوقف . r- يقوم المصرف بشراء السلعة وتسلمها وحيازتها . ب- بيع السلعة لإدارة الوقف وفقا لربح متفق عليه يضاف إلى أصل الثن . ولإدارة الوقف القيام بهذه العملية دون الحاجة لتذخل البنك (ء). ثالثا - سندات المقارضة وسنداث الاستثمار عرف " قانون البنك الإسلامي الأردني للتمويل والاستثمار رقم لسنة 9VA ام " في المادة الثانية منه، سندات المقارضة بأنها: " الوثائق الموحدة القيمة، والصادرة عن البنلك بأسماء من يكتبون فيها، مقابل دفع القيمة

(1) - د/ على محيى الدين القرة داغى- بحث حول الاستصناع صبr ابس- مجلة المجمع الفقهى الدولى - العدد السابع - المجلد الثانى.

(Y) - المرابحة العادية :في اللغة: مصدر رابح ،تقول:بعته المتاع ، أو الثتريته منه مرابحة (الفيومى:المصباح

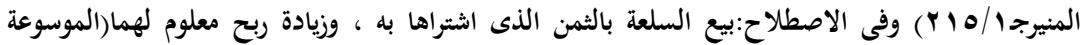

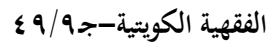

(T) - وصورتها : أن يتقدم شخص إلى المصرف يريد شراء سلعة(سيارة مثلا) بمواصفات معينة، فيقوم

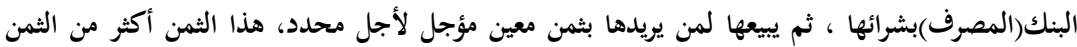

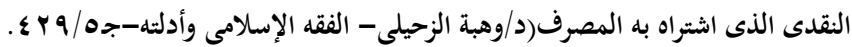

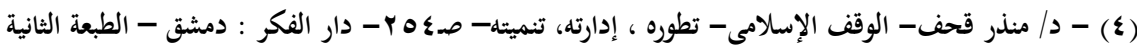




\section{الوقف مقاصده وطرق استثماره}

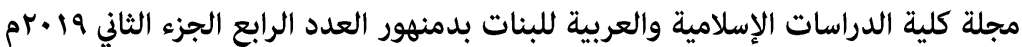

المحررة بها، على أساس المشاركة في نتائج الأرباح المتحققة سنوبا حسب إبه

الثروط الخاصة بكل إصدار على حدة "( (").

وهذه السندات بديل إسلامى للسندات التقليدية المحرمة وفقا لقرار مجمع

الفقه الإسلامى الدورة السادسة ( القرار رقم r/1/7/7) كوذه السندات

تصدر وفقا لضوابط وشروط محددة أقرها مجمع الفقه الإسلامى (r).

وتعد هذه السندات من أقدم وأشهر السندات الوققية،وهذه السندات

المشروعة تساهم فيها إدارة الوقف إما بالاكثئاب فيها ، أو شرائها ،أو إصدارها

وفي حالة الإصدار من قبل إدارة الوقف تكون الإدارة هى المضارب وحملة

الصكوك هم أصحاب المال ، والربح بينهما حسبما يتفق عليه (r).

ولا تضمن إدارة الوقف هذه الصكوك إلا بالتعدى أو التقصير (؛).

$$
\text { البعا - المشاركة }
$$

وذلك عن طريق الاستثمار للمال الموقوف من قبل إدارة الوقف في شركة صناعية أو تجارية أو زراعية سواء أكانت هذه الثركة شركة عنان أو مفاوضة وتأخذ هذه الشركة عدة صور :ا- المشاركة العادية من خلال اتفاق إدارة الوقف مع شريك أو طرف ثان في استثار مال الوقف في مشروع مشترك بينهما ،قد يكون هذا المشروع شراء عمارات ،أو مصنع ، أو سفن أو طائرات(ه).

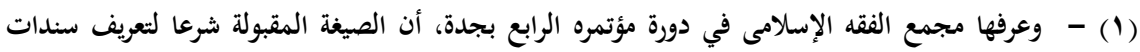

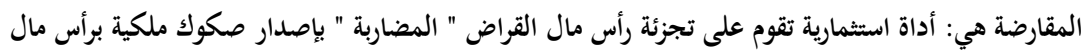

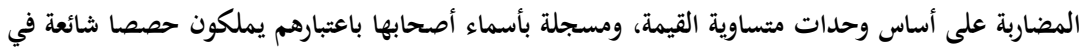

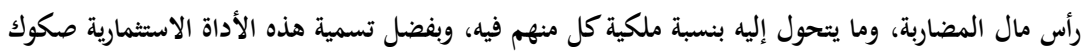
المقارضة.

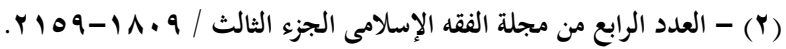

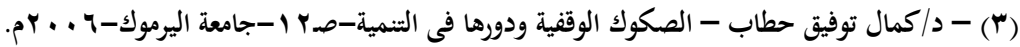

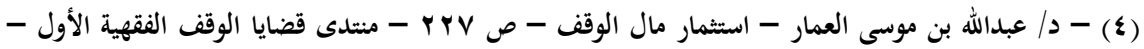

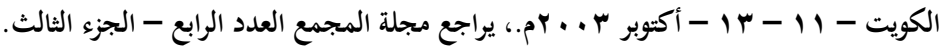

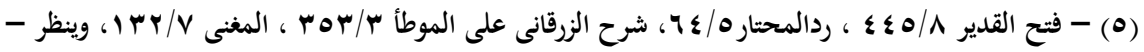

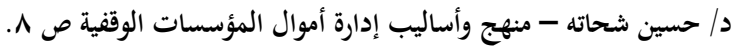




\section{الوقف مقاصده وطرق استثماره}

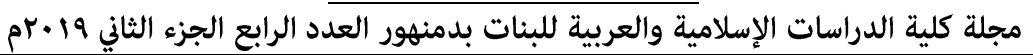

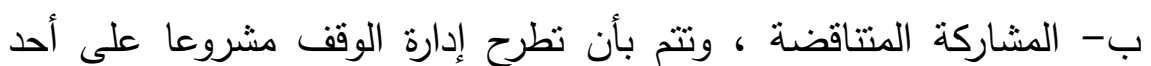

البنوك أو المستتمرين، وتتم المشاركة بينهما في بداية المشروع مشاركة بنان

عادية كل طرف بحسب ما قدمه من أموال ، ثم يبدأ الطرف الآخر

(المصرف ) الخروج تدريجيا من المشروع وذللك بييع أسهمه في فترة زمنية

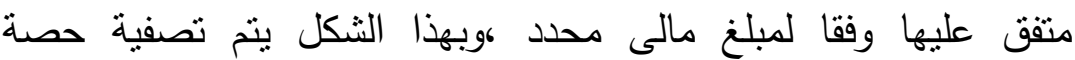

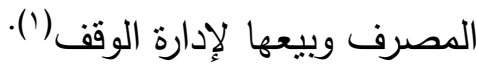

ج- المشاركة في الثركات المساهمة الحديثة إما بتأسيس شركة أو شراء أسهر

فى شركة مساهمة أخرى(r).

د- المشاركة في الصناديق الاستثمارية المشروعة بكافة صورها سواء أكانت

تقوم بنشاط واحد ، أو بعدة أنشطة .

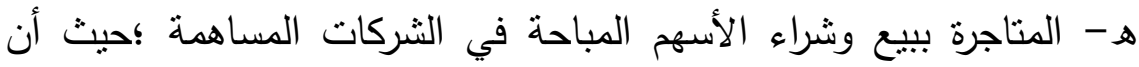
الأسهم في تلك الثركات عبارة عن صك قابل للتدوال من شخص لآخر

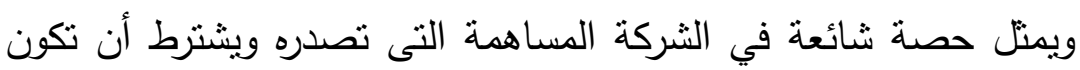
الشركة المساهمة تمارس نشاطا مشروعا وتخضع مبادئ وقواعد العمل فئل

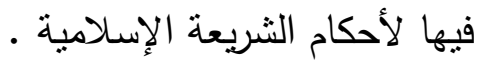

(1) - د/ على محيى الدين القرة داغى - استثمار الوقف وطرقه القديمة والحديثة ص ع |، إ - مكتبة المشكاة 


\section{الصكوك وأنواعها}

\section{تعريف الصكوك:}

في اللغة: صك ، أي ضرب ، قال تعالى " فصكت وجهها"(') : أى الى

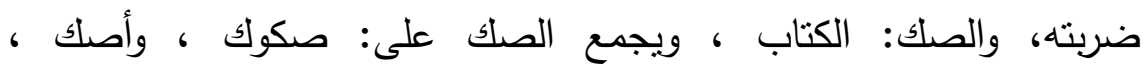

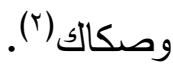

وفي الاصطلاح: عبارة عن وثائق منساوية القيمة تمنل حصصا شائعة

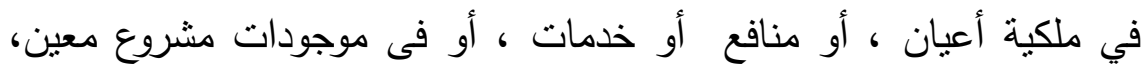

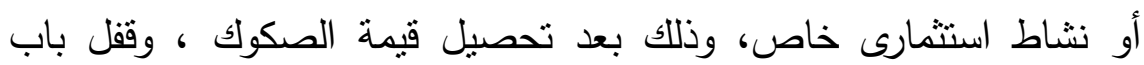
الاكتتاب ، وبدء استخدامها فيما أصدرت من أجله (r). أنواع الصكوك :تتتوع الصكوك إلي أنواع منها:

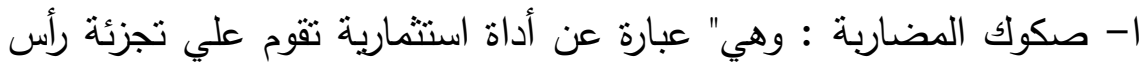

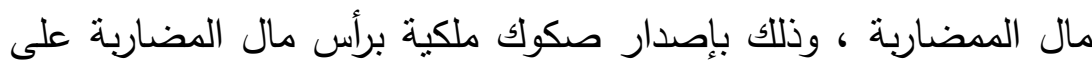

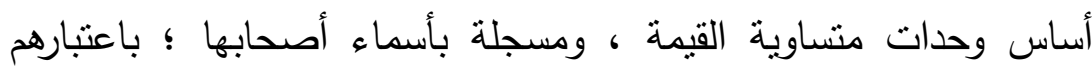

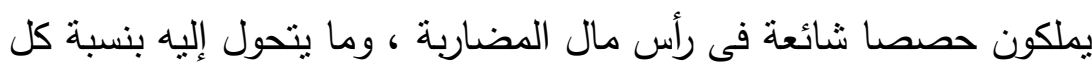

$$
\text { منهم فيه"(£). }
$$

\section{وتتنوع صكوك المضاربة إلي نوعين:}

1 - صكوك المضاربة المطلقة.

ז- صكوك المضاربة المقيدة.

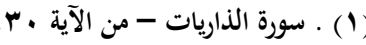

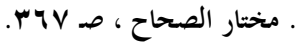

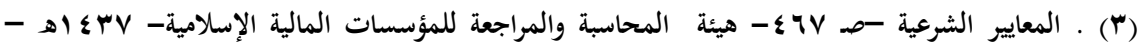

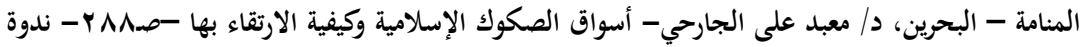

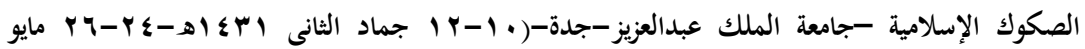

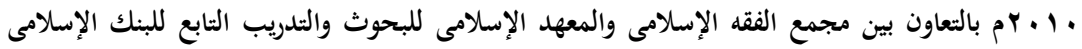

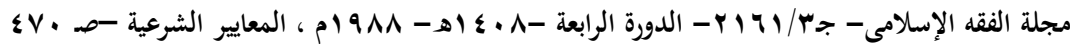

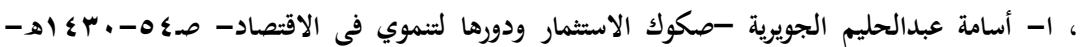




\section{الوقف مقاصده وطرق استثماره}

مجلة كلية الدراسات الإسلامية والعربية للبنات بدمنهور العدد الرابع الجزء الثاني 19 •rمافمافوه ب - صكوك الإجارة: وهى" عبارة عن وثائق متساوية القيمة تمثل حصة شائعة في ملكية أعيان ومنافع أو خدمات فى مشروع اسثثماري يدر دخلا، والغرض منها تحويل الأعيان والمنافع والخدمات التى يتعلق بها عقد الإجارة إلي أوراق مالية صكوك قابلة للتداول فى الأسواق الثانوية"(1).

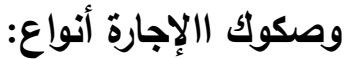

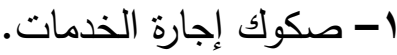

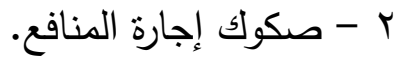

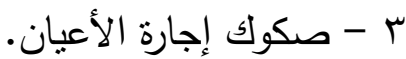

جـ - صكوك المشاركة :وهي" عبارة عن وثائق منساوية القيمة ؛ يتم إصدارها

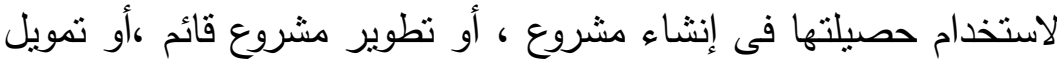

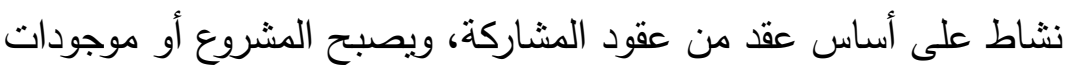
النشاط ملكا لحملة الصكوك فى حدود حصصهم، وهذه الصكوك تدار

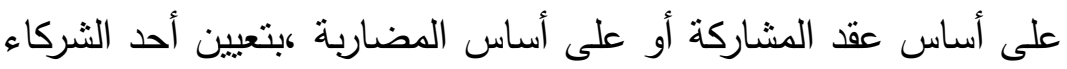

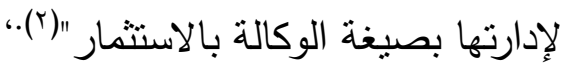
وتنتوع إلى: 1 1 r وتعد شركة العنان هي الأساس الفقهى لصكوك المشاركة.

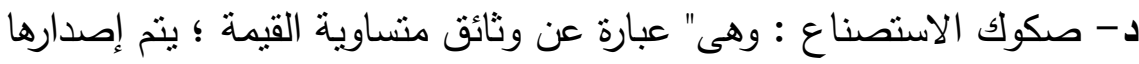

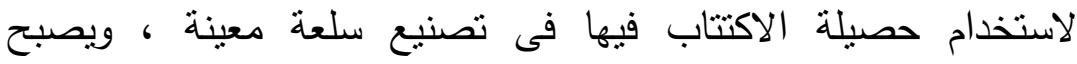
المصنوع مملوكا لحملة الصكوك"(r).

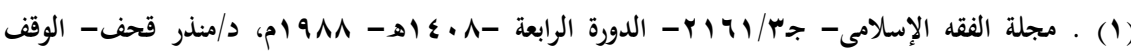

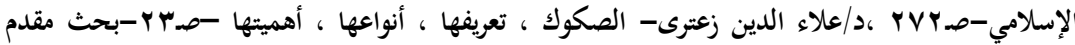

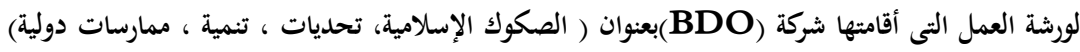

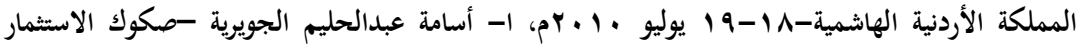
ودورها لتنموي فى الاقتصاد-صمى الإنها وما بعدها.

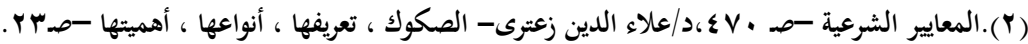

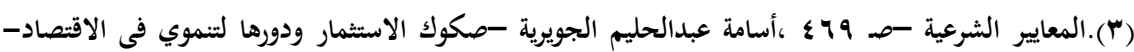




\section{الوقف مقاصده وطرق استثماره}

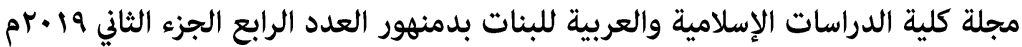

هـ - صكوك السلم: وهى "عبارة عن وثائق تصدر متساوية القيمة ؛يتم إصدارها لتحصيل رأس مال السلم ، وتصبح سلعة السلم مملوكة لحملة

(1) (1) (1) - (1)

و - صكوك المرابحة : وهي "عبارة عن وثائق تصدر منساوية القيمة ؛يتم إصدارها لتمويل شراء سلعة بالمرابحة ، وتصبح سلعة المرابحة مملوكة

لحملة الصكوك"(r).

ز - صكوك المزارعة: وهي " عبارة عن وثائق تصدر متساوية القيمة كيتم

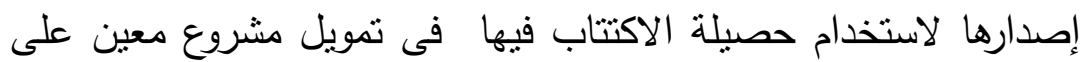
أساس المزارعة ، ويصبح لحملة الصكوك نصيب في المحصول وفق ما

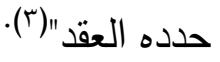

ح - صكوك المساقاة: هي"عبارة عن وثائق تصدر منساوبة القيمة ؛يتم إصدارها لاستخدام حصيلتها فى سقى أشجار مثمرة ، والإنفاق عليها ،ورعايتها على أساس عقد المساقاة ، وبصبح لحملة الصكوك حصة من الثمرة وفق ما حدده العقد"(£). ط - صكوك المغارسة: هى "عبارة عن وثائق تصدر منساوية القيمة بتم إصدارها ؛ لاستخدام حصبلتها فى غرس أشجار ، وفيما بتطلبه هذا الغرس من أعمال ونفقات على أساس عقد المغارسة ، وبصبح لحملة الصكوك حصة فى الأرض والغرس" (0).

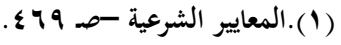

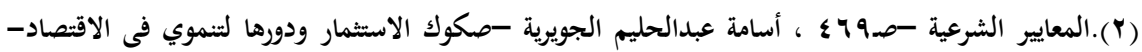

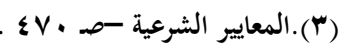

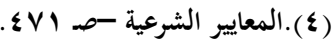

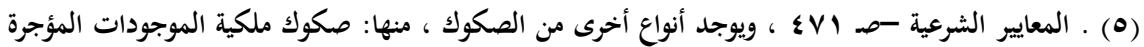

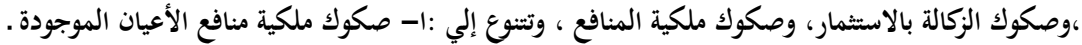

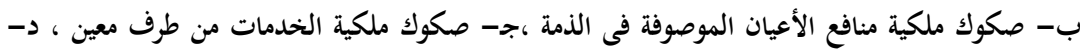
صكوك ملكية الخدمات من طرف موصوف في الذمة. 


\section{الوقف مقاصده وطرق استثماره}

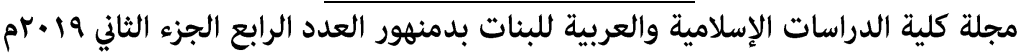

\section{المبحث الريع}

إدارة الوقفـ

صيانته وتثمبره

إدارة الوقف والمحافظة عليه وضمان بقائة واستمراره ليدوم نفعه من

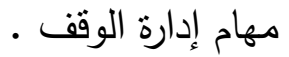

ويدخل في إدارة الوقف صيانته وإصلاحه والعناية به وهذه العمارة تتم

على وجهين :-

الأول :- صيانة (')الموقوف حتى ولو كان صالحا للانتفاع به ؛لأن

الصيانة تحفظ الأشياء ، وتتم الصيانة من قبل خبراء ومتخصصين في هذا

$$
\text { الثأن (الصبانة الوقائية ). }
$$

الثانى :- تزميم الموقوف ، وبناء ما تهدم منه ؟ حتى يعود إلى الحالة

التى كان عليها قبل (الصبانة العلاجية ) (r).

ويترتب على أهمية العمارة الأمور الأثية :-

1 - تقدم عمارة الوقف وصيانته على سائرين المستحقين الموقوف عليهم ؛ لأن دوام صرف الغلة للمستحقين يتوقف على دوام الوقف وهى لا تشتمر إلا بعمارة الوقف وهذا رأى الحنفية والمالكية والثافعية (r).

(1) - ينبغى أن تكون هذه الصيانة ضرورية ، وبدونها يترتب عليها الخراب والتلف للشئ الموقوف ، مما يعطل

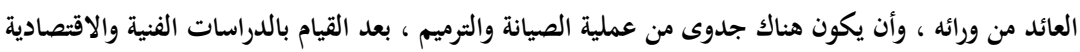

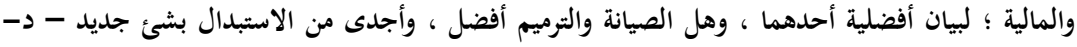

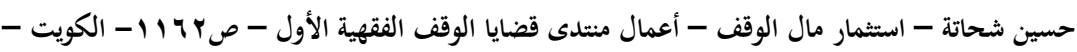

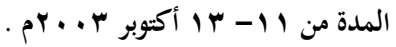

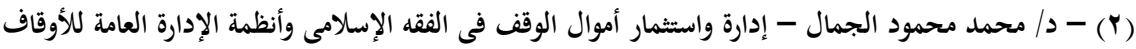

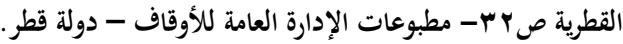

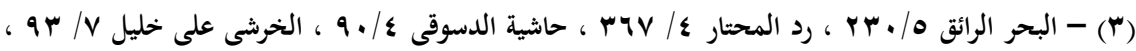

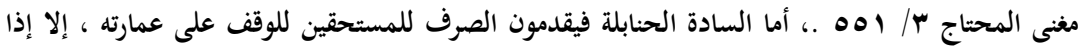

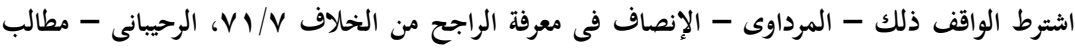

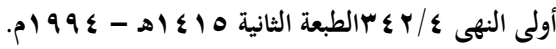


الوقف مقاصده وطرق استثماره

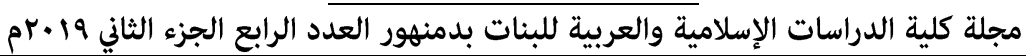

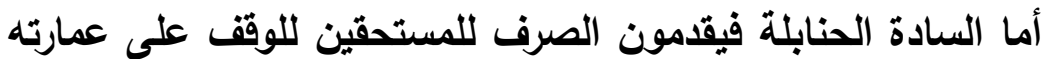

إلا إذا اشترط الواقف ذلك .

r - بطلان شرط الواقف عدم إصلاح ما خرب من الوقف ،فلا يلتزم بهذا

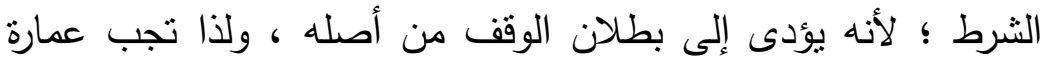

الوقف ؛ لأن فيها ديمومة الوقف واستمراره وهذا عند المالكية (').

تثمير الوقف

من وظائف إدارة الوقف تثمير الوقف ، والاعتتاء بأموره والقيام بمصالحه ؛لأن فيها نفعا للموقوف عليه .

وسلطة إدارة الوقف هنا ليست مطلقة تتصرف في مال الوقف كما

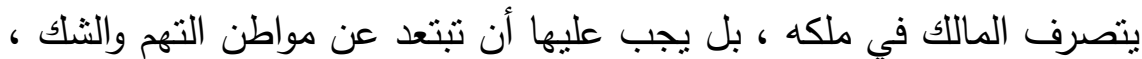

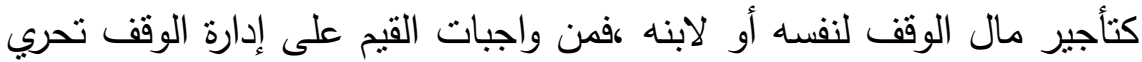

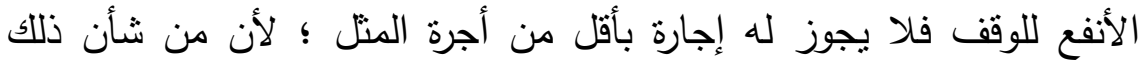

الإضرار بالوقف والموقوف عليه .

ومن حسن النظر في إدارة المال الموقوف اختيار أنسب الطرق وأجداها

لتحقيق عائد أكبر من الثئ الموقوف يعود نفعه على المستحقين ، فلإدارة

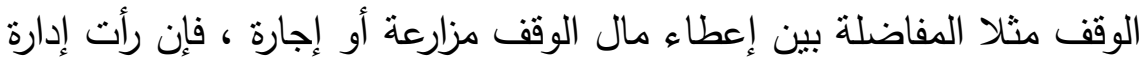

الوقف أن المزارعة أنفع للمستحقين للوقف كان لها ذلك وأنفذته (؟).

فالمال الموقوف استغلاله وادارته يختلف باختلاف العين الموقوفة ،

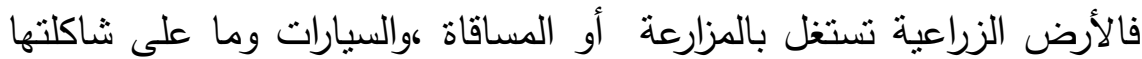
تستغل بالتأجير ...... وهكذا . ل

فتثمير المال الموقوف الذى هو إحدى مهام إدارة الوقف يتتوع بحسب

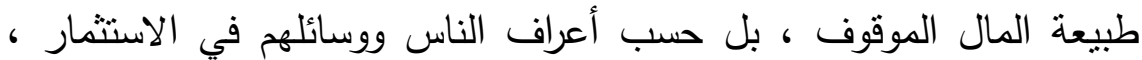

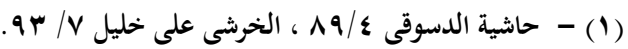

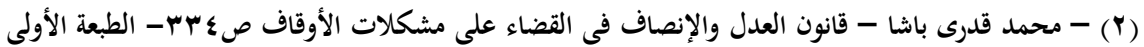
VY

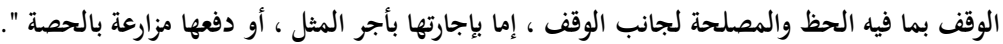




\section{الوقف مقاصده وطرق استثماره}

مجلة كلية الدراسات الإسلامية والعربية للبنات بدمنهور العدد الرابع الجزء الثاني 19 •rم

إلا أن أيدى إدارة الوقف مقيدة ومغلولة بكون هذه الطرق مشروعة كالتجارة

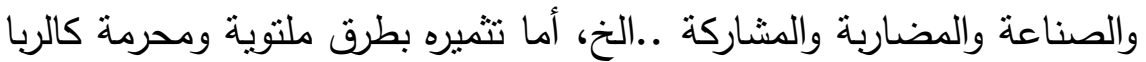
والقمار والمضاربات غير المشروعة فيحرم تتمية مال الوقف واستثماره بهذه

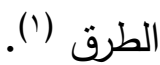

وعلى إدارة الوقف الاستفادة من النظم الحديثة ، ووسائل التخطيط

المالى والنقدى ، واستخدام القوائم والتقارير المالية التى تساهم في إيضاح

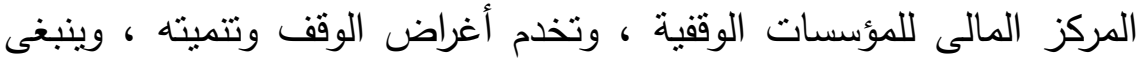

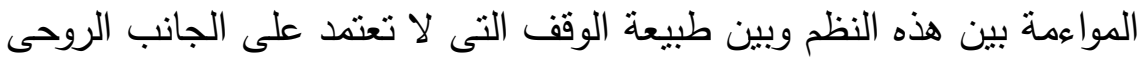

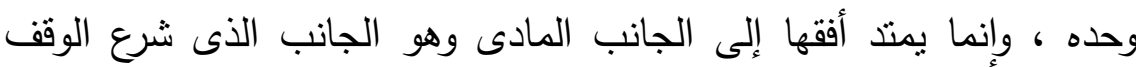

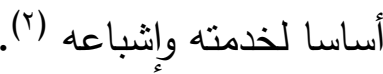

\section{خلاصة القول}

من الواجب على إدارة الوقف استغلال الوقف وتثميره بحسب طبيعة

المال الموقوف ، مستقيدة من النظم المعاصرة ، وطرق الاستثمار الحديثة ، خصوصا وأن الوقف بذاته يتضمن بناء ثروة إنتاجية من خلال عملية استثمار حاضرة ، تتظر بعين البر والإحسان للأجيال القادمة ، وتقوم على التضحية الآنية بفرص استهلاكية مقابل تعظيم الثروة الإنتاجية التى تعود خيراتها على لعي مستقبل حياة المجتمع بأكمله(َ).

\section{اجتهاد إدارة الوقف في توزيع الوقف وتقبيمه باه}

من واجبات إدارة الوقف تحصيل غلة الوقف ( ثمرة الوقف وعائده )،لكن

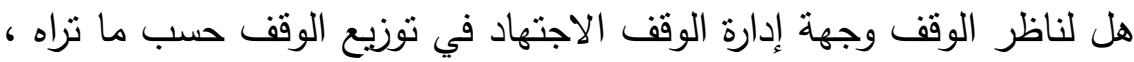

وذللك إذا خلا المال الموقوف عن كيفية توزيع مال الوقف من قبل الواقف ؟

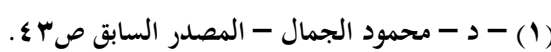

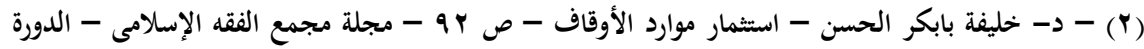

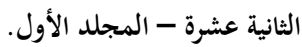

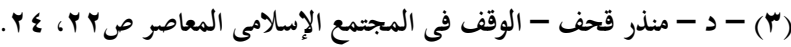




\section{الوقف مقاصده وطرق استثماره}

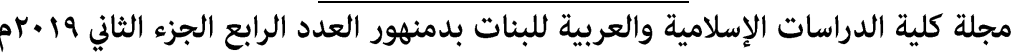
اختلف الفقهاء في هذا الأمر على أقوال :-

الأول :- برى أن لناظر الوقف الحق في إعطاء من شاء من الموقوف ألف

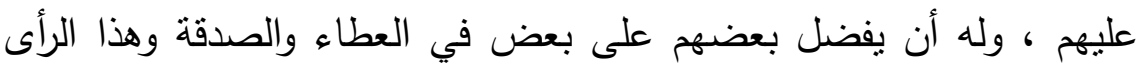
للحنفية والحنابلة (1). القول الثانى :- يرى أن لناظر الوقف تفضيل أهل الحاجة والعيال على

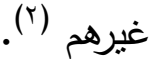

لأن قصد الواقف الإرفاق والإحسان بالموقوف عليهم، وسد خلتهم.

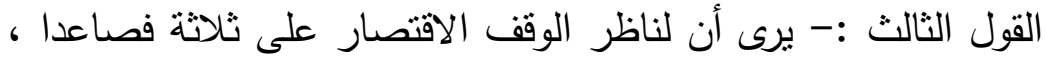
ولا يجب عليه الاستيعاب في الصرف لكل الجهة لتعذر ذلك (r). ما يجوز لإدارة الوقف من تصرفات استبدال الوقف - الاستدانة عليه - التصرف فيه تصرف المالك أولا :- استبدال مال الوقف الوفئ

استبدال مال الوقف من المسائل التى كثر حولها الجدل والخلاف بين

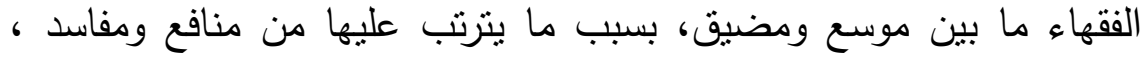

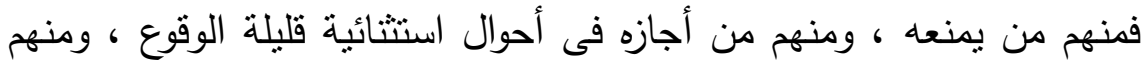

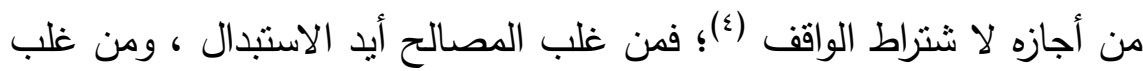

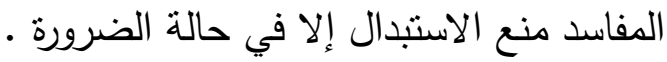
ولعل سبب الخلاف بين الفقهاء أن الاستبدال كان سببا لضياع الكثير من الأوقاف ، حيث اتخذ معدومى الأخلاق من نظار الوقف الاستبدال

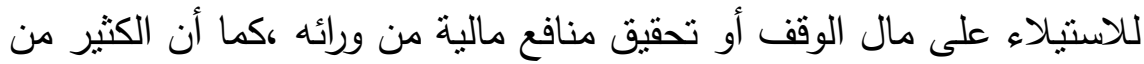

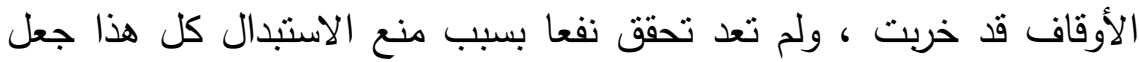

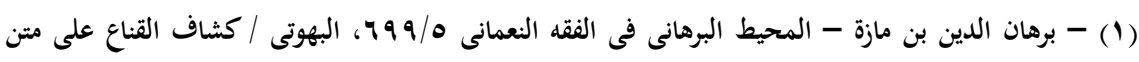

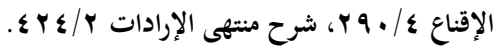

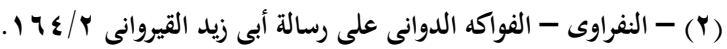

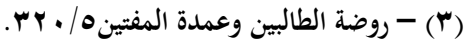

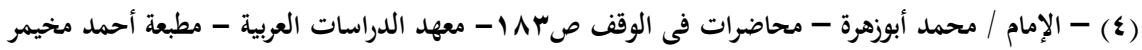




\section{الوقف مقاصده وطرق استثماره}

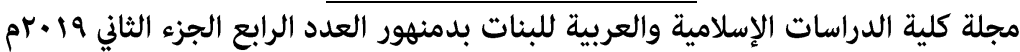

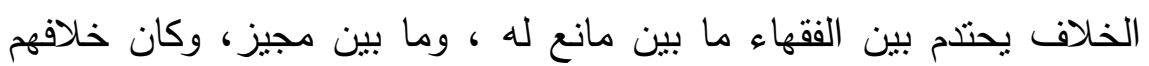

$$
\text { على النحو التالى :- }
$$

الرأى الأول - برى جواز استبدال الوقف الذى تعطلت منافعه، وصار

بحال لا يمكن الانتفاع به،كأن يخرب ، ولا يوجد ما يعمر به ، أو تلتحول

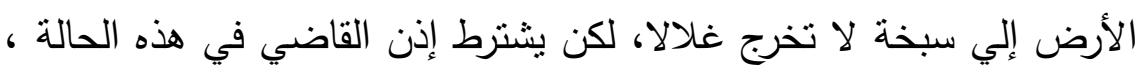

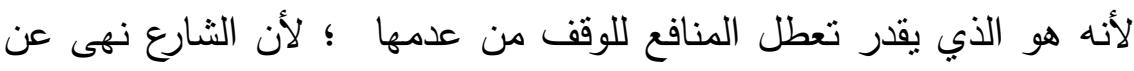

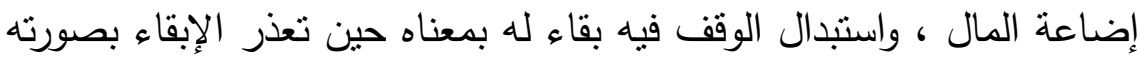

فيكون متعينا ،وهو رأي أكثر الحنفية (')

وعند السادة الحنابلة كما جاء في المغنى لابن قدامة " وإن لم تتعطل

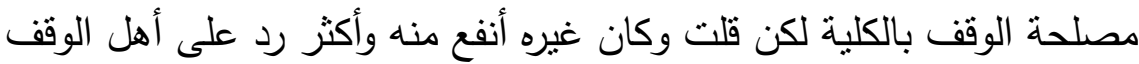

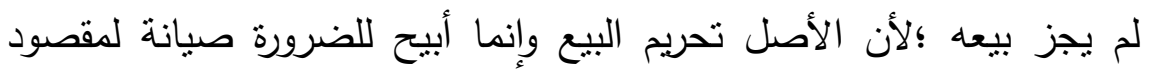
الوقف عن الضياع مع إمكان تحصيله ومع الانتفاع وإن قل ما يضيع

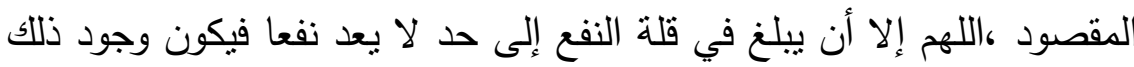

كالعدم "(r). ( - (r)

وجاء في المغني أيضا" أن الوقف إذا بيع فأي شيء اشتري بثمنه مما

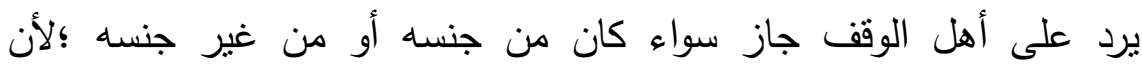

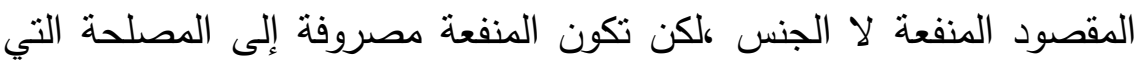

(1) - جاء في المحيط البرهاني"سئل شمس الإسلام الحلواني عن أوقاف المسجد إذا تعطلت وتعذر استغلالها هل

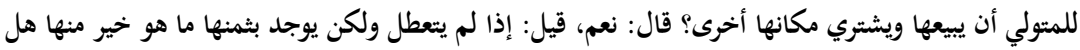

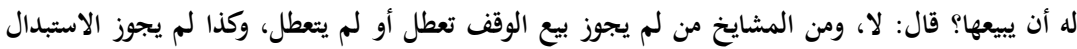

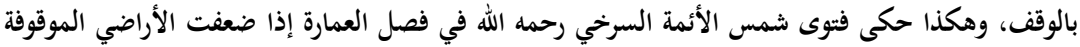

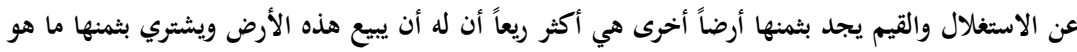

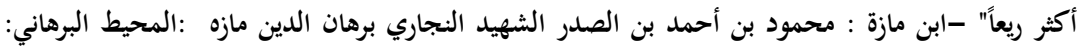

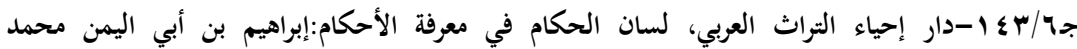

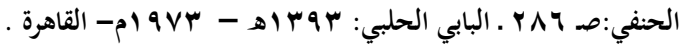

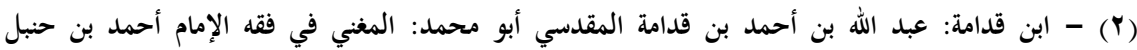

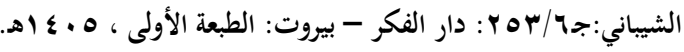




\section{الوقف مقاصده وطرق استثماره}

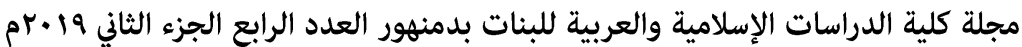

كانت الأولى تصرف فيها ؛لأنه لا يجوز تغيير المصرف مع إمكان المحافظة

عليه ،كما لا يجوز تغيير الوقف بالبيع مع إمكان الاتتفاع به "(1). والذي يقوم ببيع الموقوف عند استبداله ،وشراء ما يقوم مكانه هو الحاكم ،لا سيما إذا كان الوقف علي مصلحة عامة كالمساجد والقناطر والمساكن ،ونحوها ؛ حيث أن استبدال الوقف في هذه الحالة فسخ لعقد لازم في موضع مختلف فيه اختلافا قويا ،فتوقف الاستبدال علي الحاكم ،قياسا علي الفسوخ المختلف فيها (r).

الرأى الثانى - يرى جواز استبدال المنقول فقط ، وهو القول المعتمد عند المالكية(r)وذلك إذا دعت المصلحة لذلك ، كما لو تعطلت منافعه وصار في حالةلا ينتفع به ، أو خيف عليه الهالك ولم ينفق عليه أحد (ع).

$$
\text { (1) - (1) - المغني لابن قدامة - الموضع السابق نفسه. }
$$

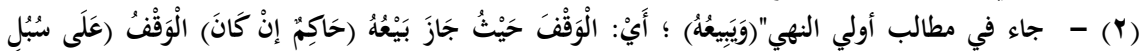

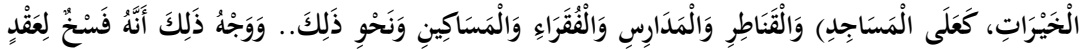

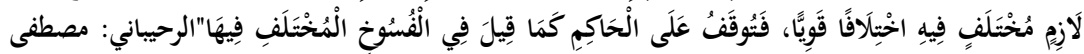

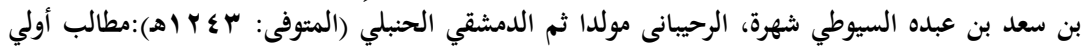

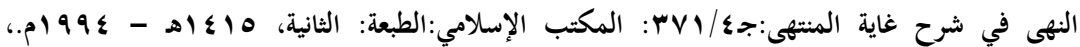

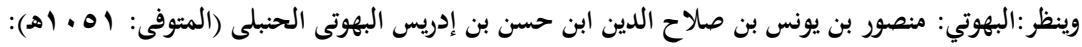

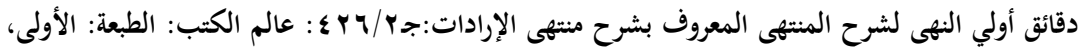

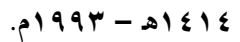

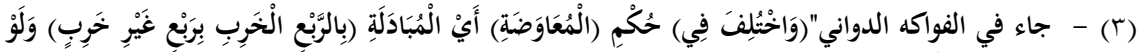

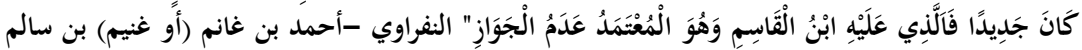

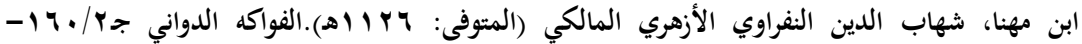

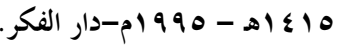

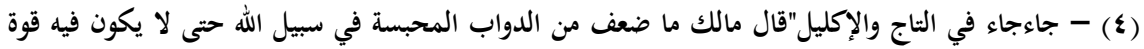

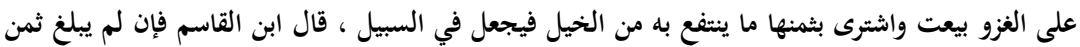

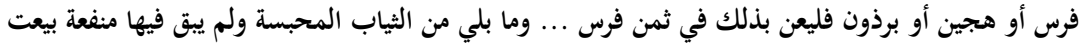

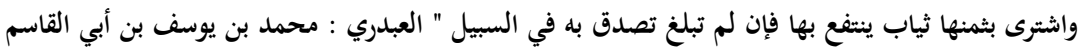

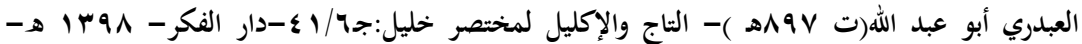

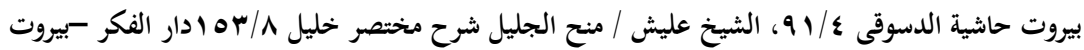




\section{الوقف هقاصده وطرق استثماره}

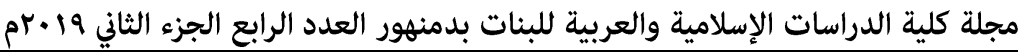

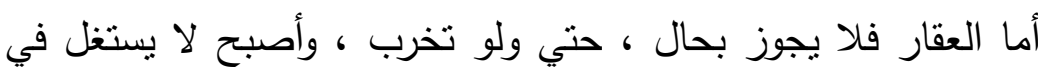

شئ، وخصوصا إذا كان مسجد ، أو عقارا ذا غلة ، فلا يباح بيعه ولا استبداله

، إلا لضرورة تقتضي ذلك من توسيع مسجد أ ومقبرة أو طريق عام (1).

لكن بعض المالكية(ابن رشد) أجاز استبدال العقار بعقار آخر بحل

محل العقار الموقوف ، الذي تعطلت منافعه ، ولا ينتظر أن يأتي بنفع

(ب) إطلاقا).

والتفرقة عند المالكية بين العقار والمنقول في جواز الاستبدال أساسه؛

هو رجاء الانتفاع بالعقار في المستقبل، فتشددوا في استبداله ، وعدم رجاء ذلك

في المنقول فلم بتشددوا في استبداله(r).

الرأى الثالث :- يرى أنه لا يجوز استبدال العقار الموقوف الذى تعطلت

منافعه ، أما المنقول ففيه وجهان ، المنع مطلقا ، الثانى جواز بيع المنقول الذى لا يرجى من ورائه أية منفعة ، حيث يعد البيع أولى من الترك وهو

للثافعية (ع)

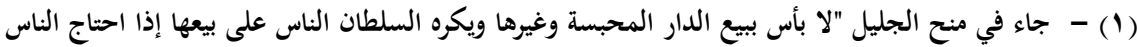

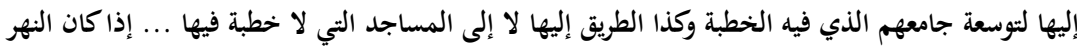

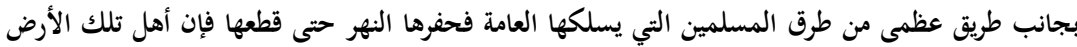

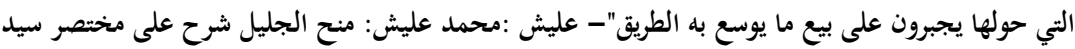

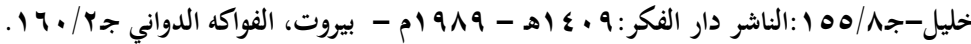

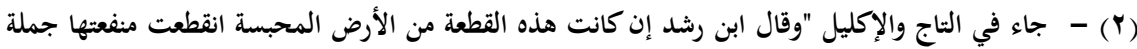

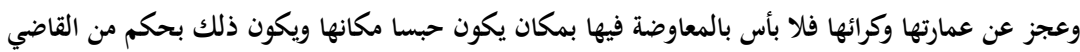

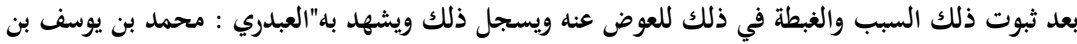

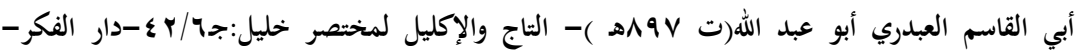

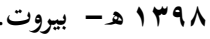

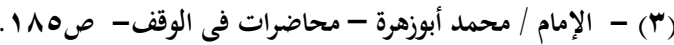

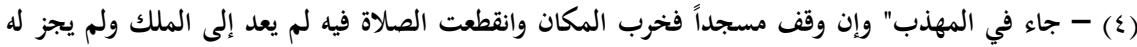

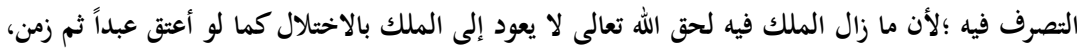

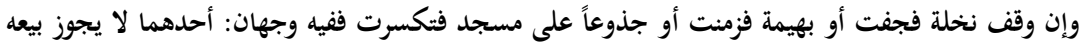

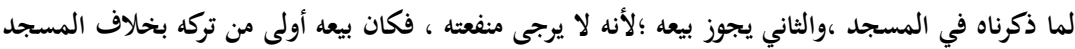

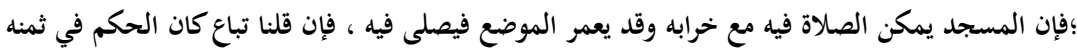

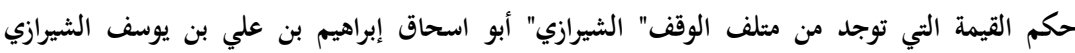

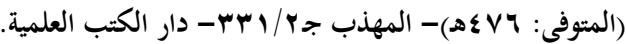




\section{الوقف مقاصده وطرق استثماره}

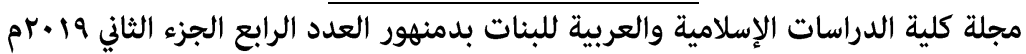

فالثافعية تشددوا في استبدال الموقوف ، حتي ولو لم يعد صالحا

إلا باستهلاكه ، فيمنع عندهم بيعه ، لكن يجوز للموقوف عليهم استهلاكه ،

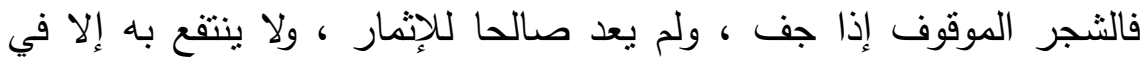
اتخاذه وقودا ، كان للموقوف عليهم أن يتخذوا وقودا ، لكن لا يجوز لهم بيعه ؛ حيث أن صفة الوقف لم تزل عنه ،وبالتالي هذه الصفة تمنع من البيع منعا

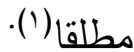

ولعل رأى السادة الحنفية هو الرأى الأقرب للقبول بالضوابط والثروط

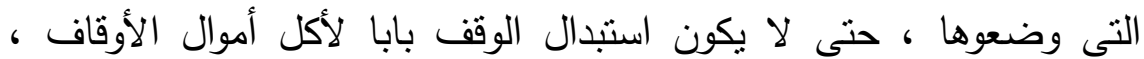
وحتى نسد الباب على من تسول له نفسه الاستيلاء على مال الوقف عند تعطله وخرابه ، ولا نضيع فرص استغلاله واستثماره ، فالإفراط في النتشيد في

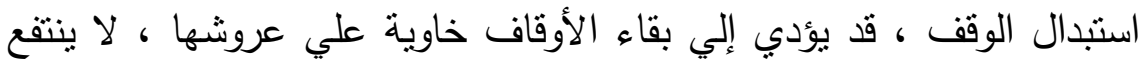

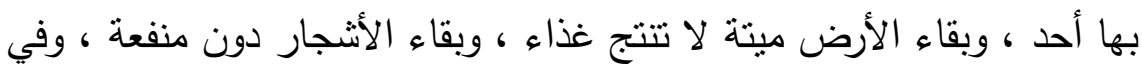

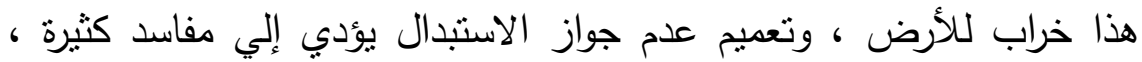
وسوء استغلال ، وفيه كذلك إضرار بالمستحقين للوقف ، والفقراء ، وجهات البر ، كما يؤدي إل انقطاع الأوقاف بمرور الزمن ونوالي الأحداث(باث).

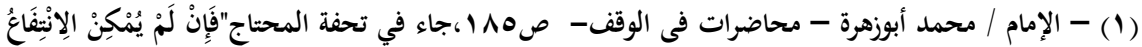

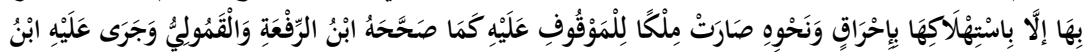

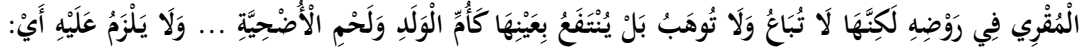

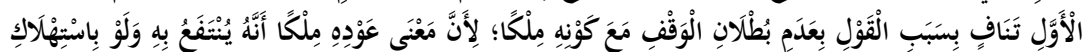

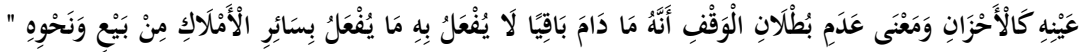

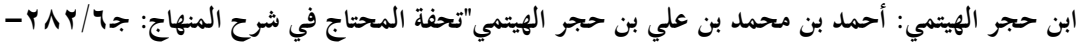

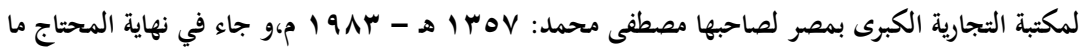

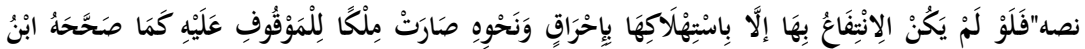

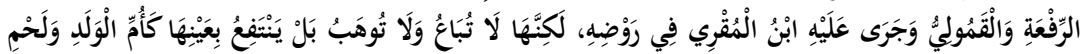

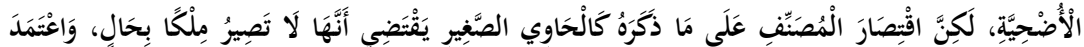

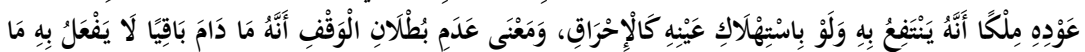

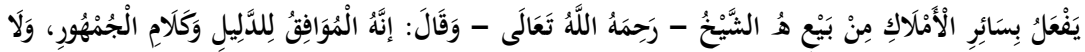

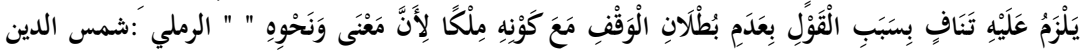

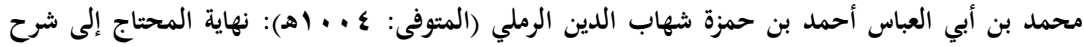

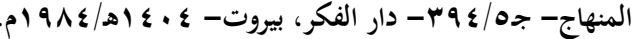

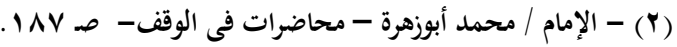




\section{الوقف مقاصده وطرق استثماره}

مجلة كلية الدراسات الإسلامية والعربية للبنات بدمنهور العدد الرابع الجزء الثاني 19 •rمأماره

شروط استبدال الوقف:وهذا الاستبدال عند الحنفية بجوز للقاضى فقط

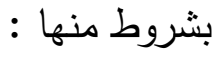

ا-أن يخرج الوقف عن الانتفاع كلية ، أي تتعطل منافعه .

r-أن يكون هنالك ربع للوقف بعمر بـه.

ب-ألا يباع الوقف بغبن فاحش، وهو ما لا يدخل تحت تقوبم المقومين الخبراء ؛ ولأن البيع بغبن فاحش فيه ظلم، وتبرع بجزء من الوقف ، وهذا لا يجوز

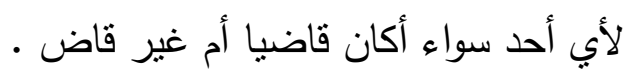

ع-أن نكون العين التي اشتربت ، واستبدل بها الوقف أكثر خيرا ، وأبعد عن

$$
\text { الضرر من العين التي بيعت . }
$$

0- أن يكون من بيولي البيع بعيدا عن الاتهام ، وشبهة المحاباة ،فلا يقبل البيع من القيم علي الوقف لمن لا تقبل شهادته له ، ولا لمن له دين علي القيم ؛ لأن البيع هنا مدعاة للاتهام ، ومن المحتمل أن يقع غبن علي الوقف ، وأن يكون التصرف ليس من مصلحته في شئ. ج- أن يكون البدل والوقف في محلة واحدة .

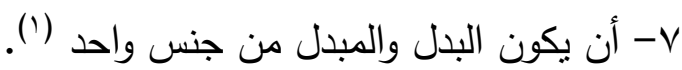

ومن يقوم بعملية الاستبدال والإشراف عليها ، القاضي ، وبنبغي أن يكون أمبنا عدلا (قاضي الجنة)؛ لئلا يكون ذلك سببا في إبطال أوقاف

المسلمين ، وضياعها (r).

\section{لكن هل من السهل معرفة القاضي العدل الأمين؟.}

يجيب علي ذلك الإمام / محمد أبو زهرة ، فيقول: إن معرفة دفائن القلوب ليس أمرا هينا لينا ، واستبطان حقائق الرجال ليس أمرا ميسورا ، وولي

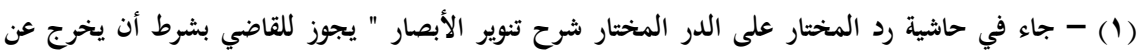

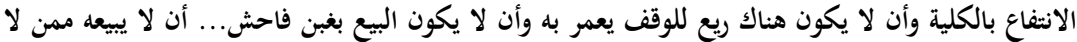

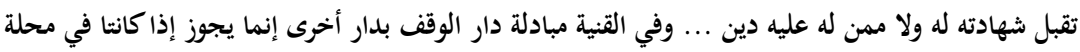

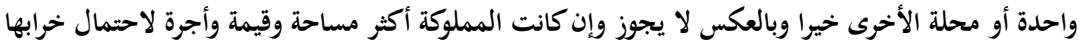

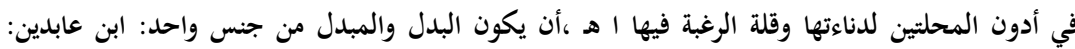

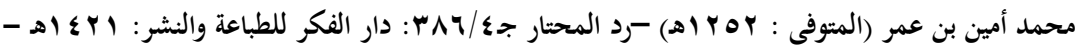

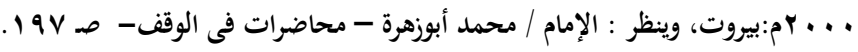

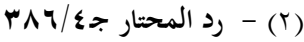




\section{الوقف مقاصده وطرق استثماره}

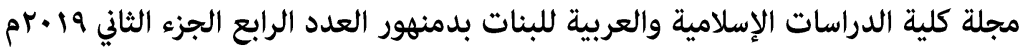

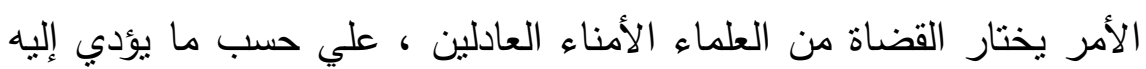

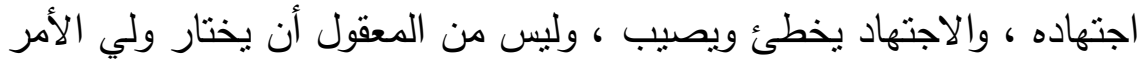

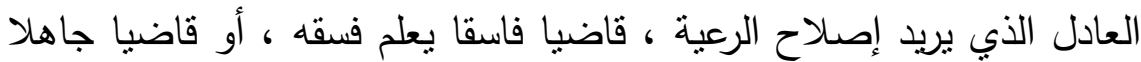

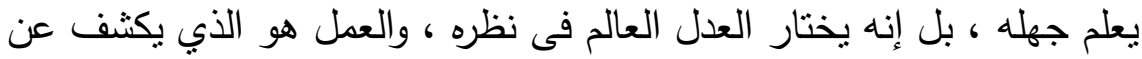

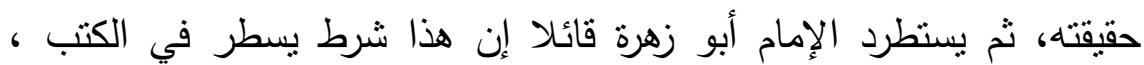

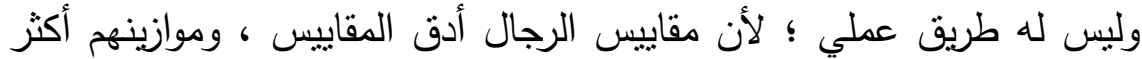
حساسية من ميزان الذهب .... وأي مقياس وضع لمعرفته(قاضي الجنةالقاضي العادل)وأي ميزان كان لتبينه ، ذللك أمره إلي اله ، ، إلي الله العليم الحكيم ، الذي يعلم ما تخفي الصدور (').

مساوئ الاستبدال : رغم إيجابيات الاستبدال في كثثر من الأحيان ، إلا هالا

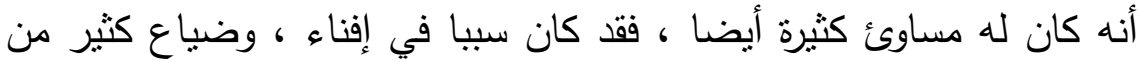
الأوقاف ، فالاستبدال ليس خيرا خالصا ، وليس شرا محضا ، ولكن الثر لئر والخير يختلطان فيه ، ويرجح الخير علي الثر إذا صلح الحاكم ، وعدل

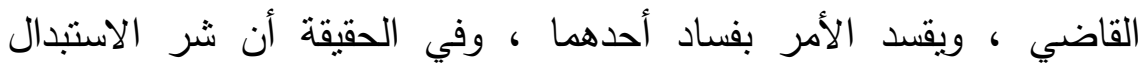

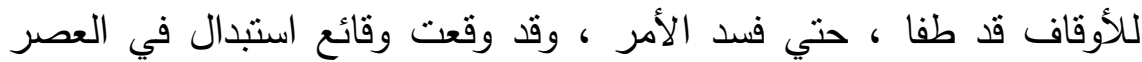
الحالي كان الغبن فيها شديدا علي الوقف ، لأن الذمم قد خربت ، والضمائر

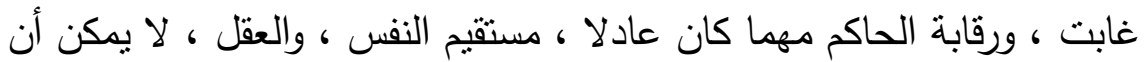

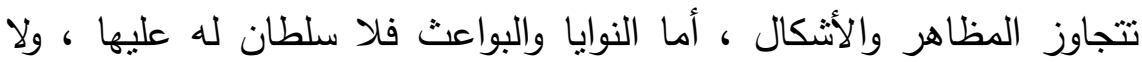




\section{الوقف هقاصده وطرق استثماره}

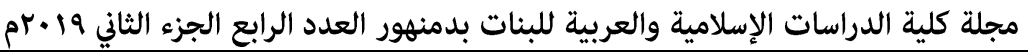

ثانيا :- الاستدانة على الوقف التف

قد يتهدم المال الموقوف ، أو يحتاج إلى تعمير وإصلاح ، أو تحتاج

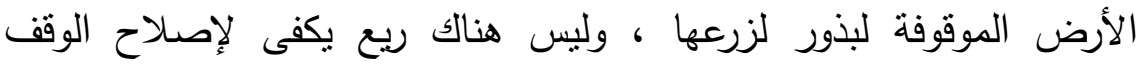

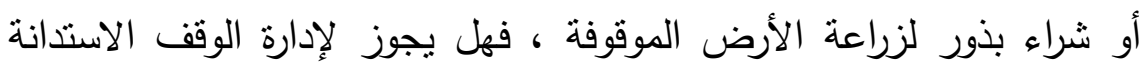

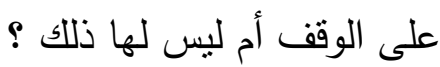

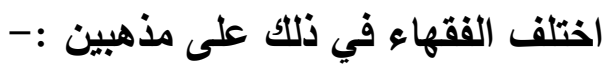

المذهب الأول - يرى أنه لا يجوز الاستدانة على الوقف ، هل إذا لم يكن

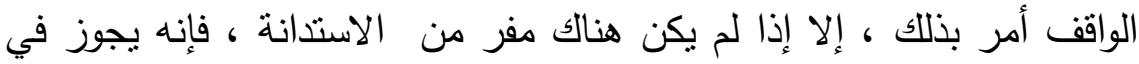

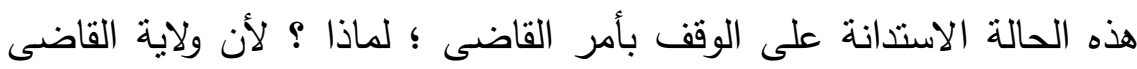
أعم وأثمل في مصالح المسلمين (وهو للحنفية والثافعية) (').

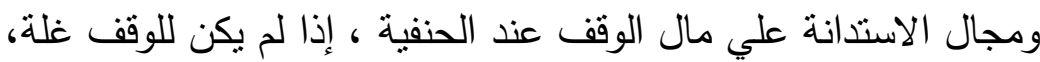

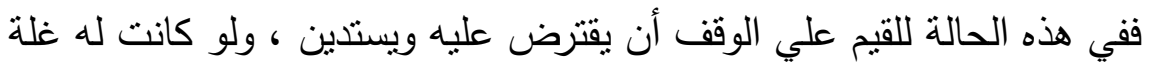

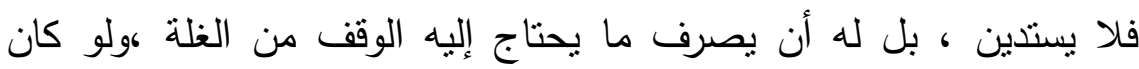

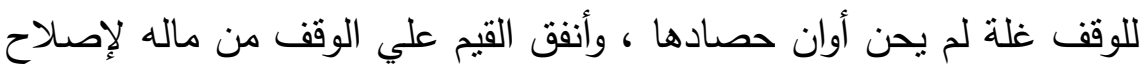

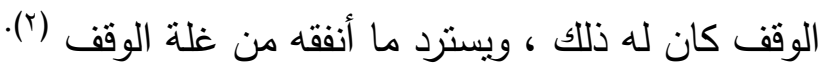

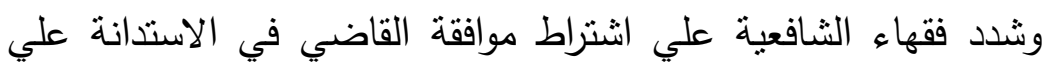
الوقف ؛ فقال العلامة السبكى في فتاويه " والقاضي هو نائب الشرع فلذلك الكي

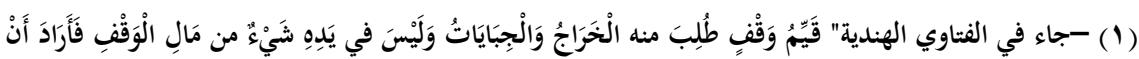

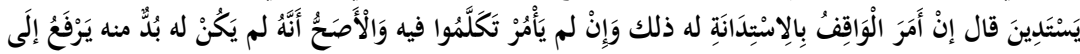

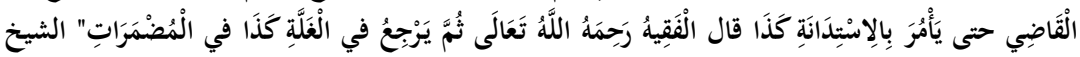

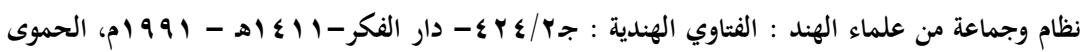

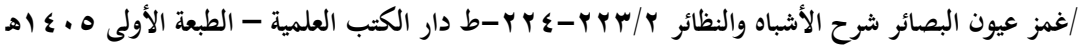

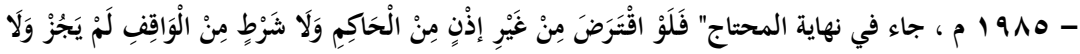

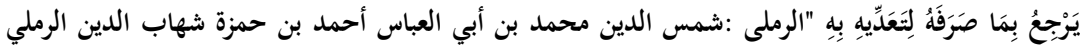

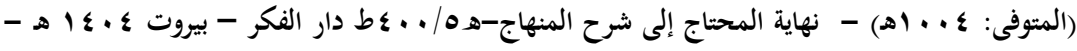

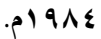

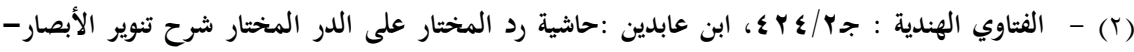

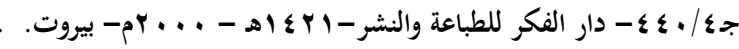




\section{الوقف مقاصده وطرق استثماره}

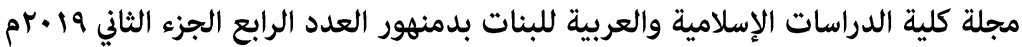

ينظر نظرا عاما على كل ناظر خاص السلطان فمن دونه كما يحكم بحكم الثرع عليهم فإذا كان القاضي هو الناظر الخاص بشرط الواقف فقد اجتمع فيه النظر الخاص والنظر العام فلا يحتاج إلى نظر عام عليه ولو فرضنا أن شرط النظر لشخص غير قاض فلا شك أن للقاضي النظر العام عليه لنائب

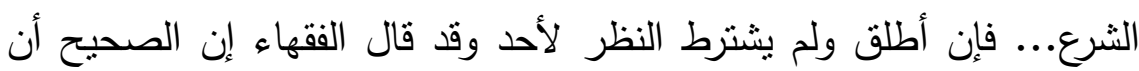
النظر للقاضي وكان عندي تردد في أن السلطان يشاركه أو لا والآن استقراري

$$
\text { على عدم مشاركته وأن القاضي ينفرد به"( (1). }
$$

المذهب الثانى - يرى جواز استدانة ناظر الوقف عليه ، متى كان

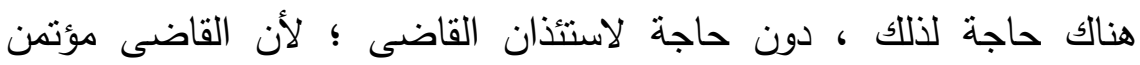

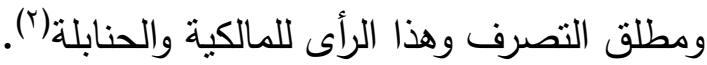

ومذهب السادة الحنفية والثافعية هو الأولى بالقبول لما سبق التعليل به لهابه من منع استبدال الوقف إلا بإذن القاضى ،أصنف لذللك أن إذن القاضى في بالهي الاستدانة على الوقف فيه مزبد من ضبط ورعاية الوقف ،وتقدير حالة الضرورة التي تستدعي الاستدانة موكول إلي القاضي ، وهو الذي يقدرها ؛ حيث أنها مسألة موضوعية يعود تقديرهل للقاضي ، كما أن له الاستعانة بذوي الخبرة في هذه المسائل، كما أن إعطاء الحرية للقيم علي الوقف في الاستدانة عليه إذا دعت الضرورة ، دون التقيد بإذن القاضي قد يجر إلي ما لا يحمد عقباه من ضياع مال الوقف ، أضف لذلك أن شراء بعض الضروريات التي يحتاجها

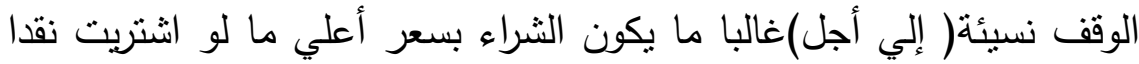

(1) - السكي : الامام أبي الحسن تقي الدين علي بن عبد الكافي السبكي(ت بVهOAه)- فتاوي السبكي -

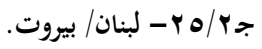

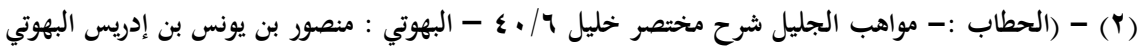

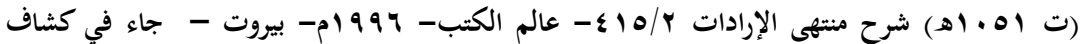

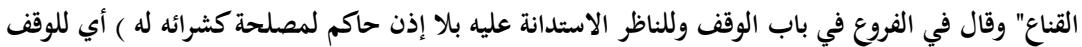

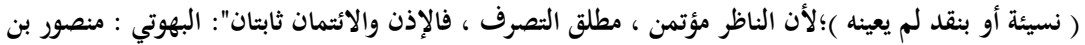

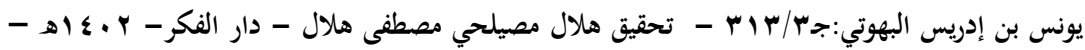




\section{الوقف مقاصده وطرق استثماره}

مجلة كلية الدراسات الإسلامية والعربية للبنات بدمنهور العدد الرابع الجزء الثاني 19 •rم

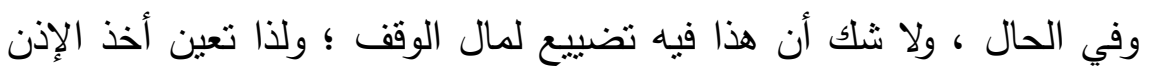

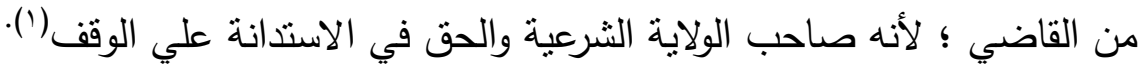

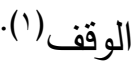

\section{ثالثا :- التصرف فيه تصرف المالك}

بمجرد الوقف من قبل الواقف تتنقل ملكية الرقبة الموقوفة إلى ملك الله

سبحانه وتعالى كما ذهب إلى ذلك الثافعية وأبو يوسف ومحمد من الحنفية(؟).

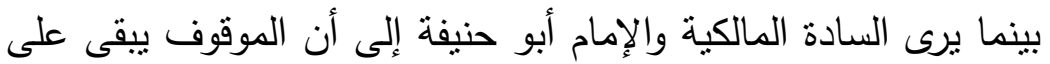

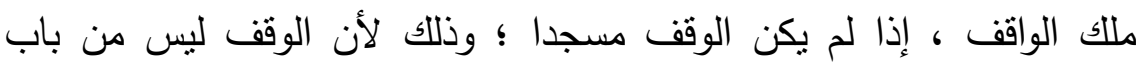

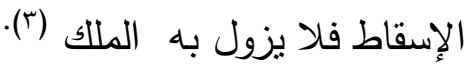

أما الحنابلة فقرقوا بين ما إذا كان الموقوف على شخص أو جهة معينة وبين ما يوقف على جهة عامة ،فلو كان المال وفقا على شخص أو جهة أنهان معينة ظل على ملك الواقف ، أما لو كان موقوفا على جهة عامة فينتقل الملك الك

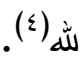

\section{هل يجوز بيع الموقوف ؟.}

لبيع الوقف صور ، منها بيع الوقف مطلقا ، وهو التصرف فيه من قبل

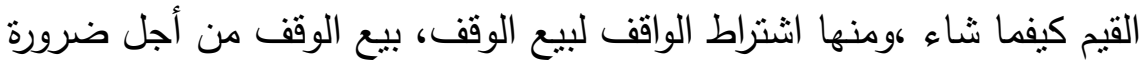

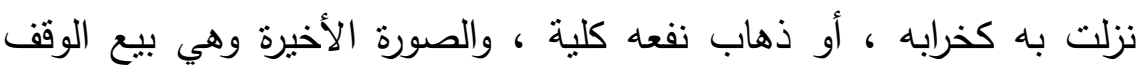

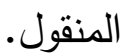

\section{ا- بيع الوقف مطلقا (الصورة الأولي).}

وفي هذه الصورة يتصرف القيم علي الوقف تصرف المالك فيما يملك، فيبيع عين الوقف ، ويقبض ثمنها ، فما حكم تصرف القيم علي الوقف ؟.

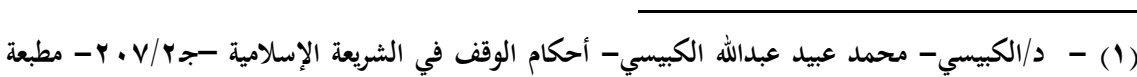

$$
\begin{aligned}
& \text { الإرشاد - بغداد- ( } \\
& \text { ا }
\end{aligned}
$$

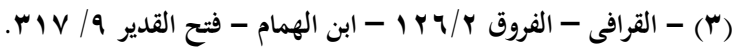

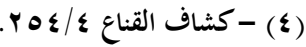




\section{الوقف مقاصده وطرق استثماره}

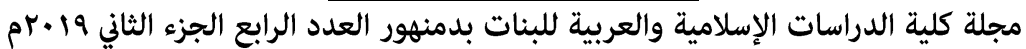

اختلف فيه الفقهاء علي النحو التالي:

المذهب الأول :يري عدم جواز بيع الوقف (وهذا الرأي لجمهور العلما من أئعة المذاهب ، كأبي يوسف في قول له ، ومحمد ، والمالكية والثنافعية والحنابلة (1).

المذهب الثاني : يري جواز بيع الوقف (وهو لأبي حنيفة ، وأبي يوسف

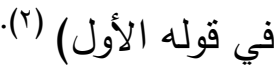

استدل أصحاب المذهب الأول علي ما ذهبوا إليه من عدم جواز بيع الوقف :

ا- ما جاء في الحاوي للإمام الماوردي من الإجماع علي عدم جواز بيع

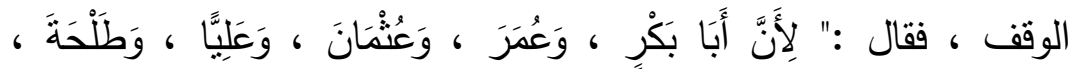

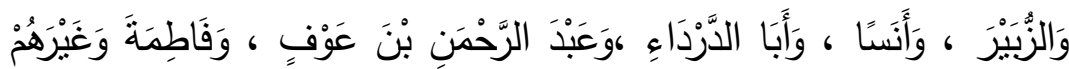

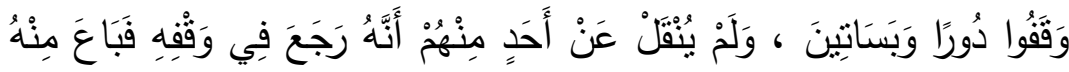

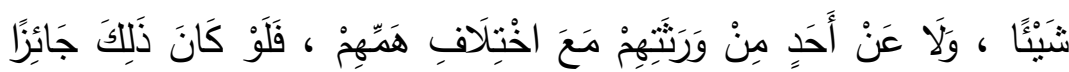

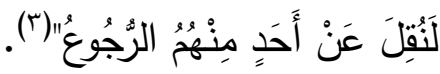

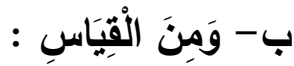

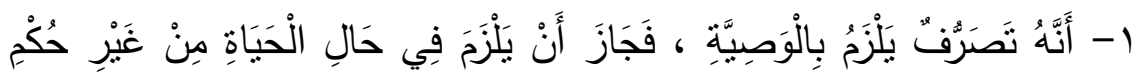

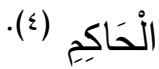

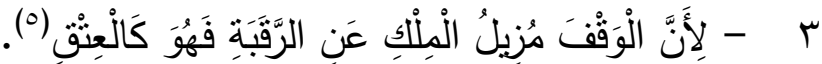

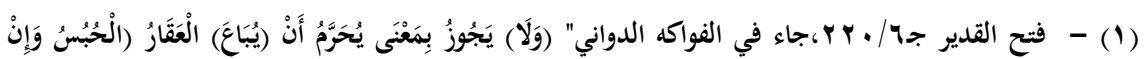

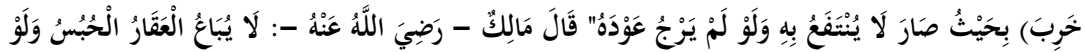

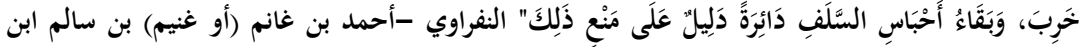

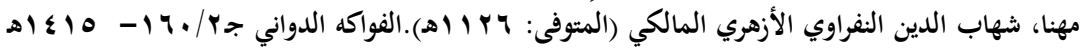

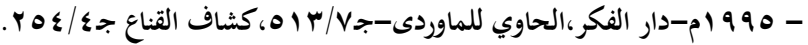

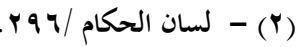

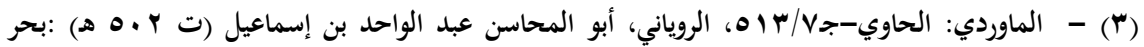

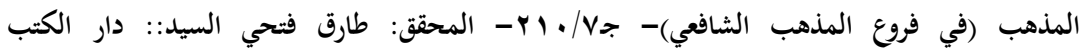

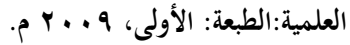

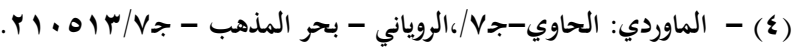

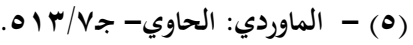




\section{الوقف مقاصده وطرق استثماره}

مجلة كلية الدراسات الإسلامية والعربية للبنات بدمنهور العدد الرابع الجزء الثاني 19 •rم

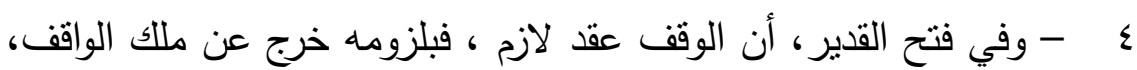

$$
\text { قياسا علي من لا ملك له ('). }
$$

استثل أصحاب المذهب الثاني علي جواز بيع الموقوف :

القياس من وجهين :

الوجه الأول من القياس :قياس صحة بيع العين الموقوفة علي صحة

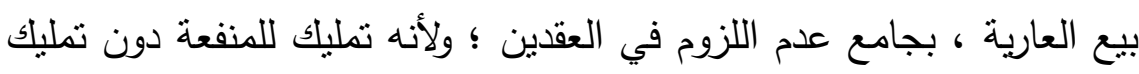

الوجه الثاني من القياس: القياس علي الوصية في التأبيد

فكلاهما (الوقف والوصية)معلق علي الموت ؛ ليصير العقد لازما (ب).

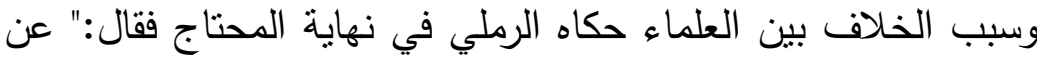

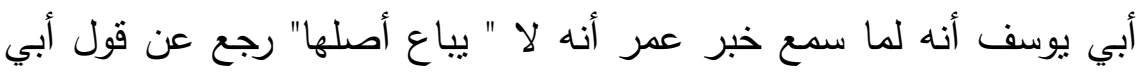

حنيفة رضي الله عنه بييع الوقف وقال لو سمعه لقال به (ع).

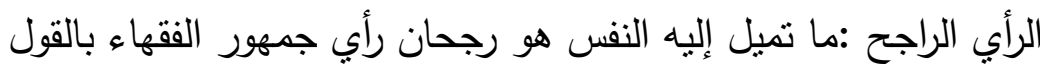

بعدم جواز بيع الرهن من قبل القيم عليه ، أو الوصي ؛حيث أن الأخذ النذ بهذا الرأي فيه تحقيق لمقاصد الوقف ، التي شرع من أجلها ، والقول بالمذهب

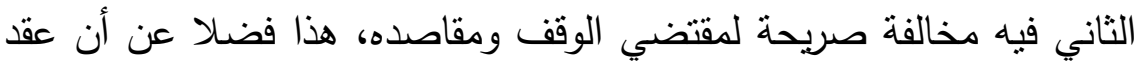

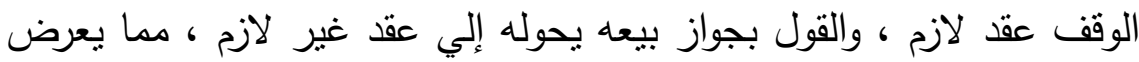

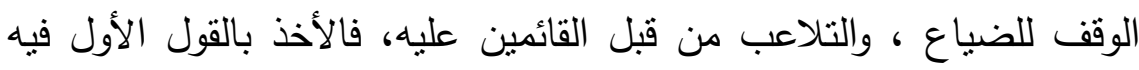
محافظة علي الوقف من العبث به.

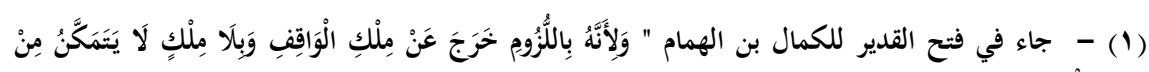

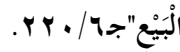

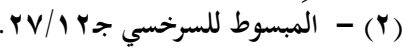

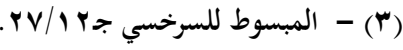

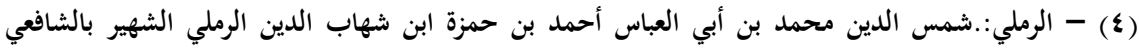

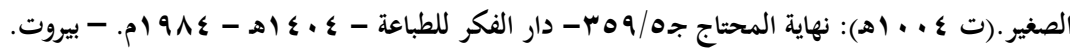


الوقف مقاصده وطرق استثماره

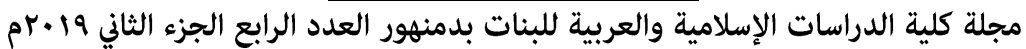

ب - اشتراط الواقف بيع الوقف (الصورة الثانية)..

هذه الصورة اختلف فيها الفقهاء علي النحو التالي:

الرأي الأول: يري عدم جواز بيع الوقف إذا اشترطه الواقف(وهو

للشافعية والحنابلة) (').

الرأي الثانى : يري جواز بيع الوقف إذا كان مشروطا من قبل

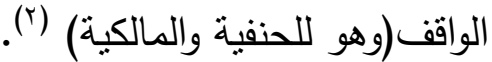

استدل الرأي الأول القائل بعدم جواز بيع الوقف إذا اشترطه الواقف بما يلي:

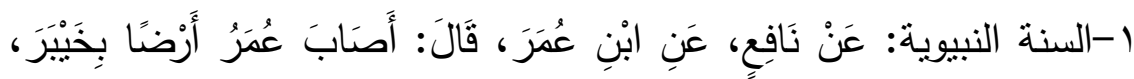

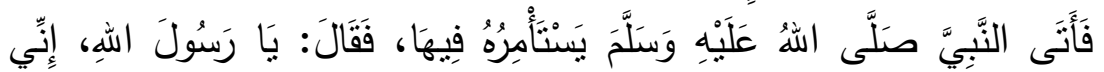

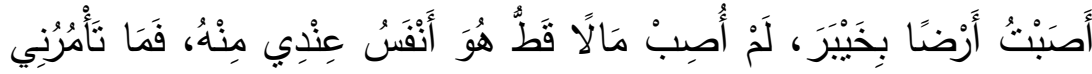

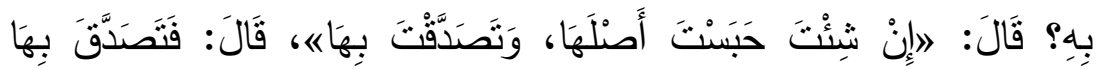

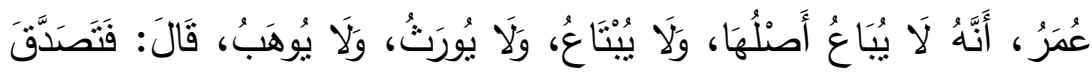

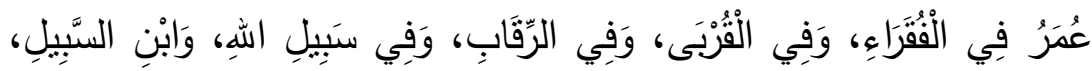

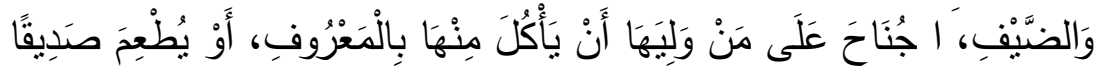

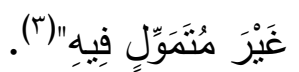

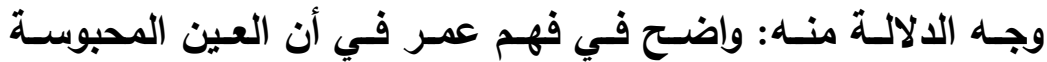

لا تباع، ولا توهب ، ولا تورث .

r-القياس: إنه إزالة ملك على وجها القربة فلا يعود إلى مالكه باختلاله وذهاب

منافعه كالعتق (๕).

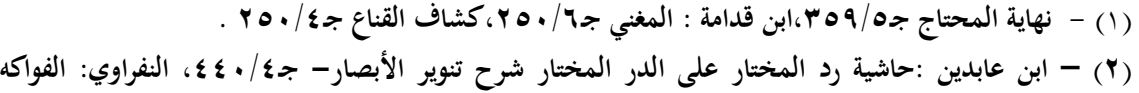

الدواني -جر/ • • 17

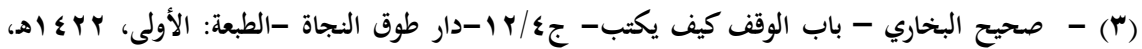

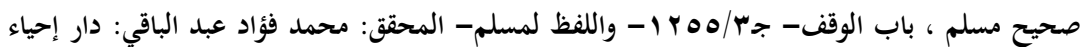

التراث العربي - بيروت.

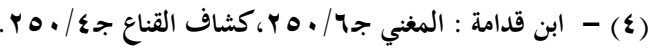




\section{الوقف مقاصده وطرق استثماره}

مجلة كلية الدراسات الإسلامية والعربية للبنات بدمنهور العدد الرابع الجزء الثاني 19 •rم r-المعقول: ولأنه لو كان تمليك المنفعة المجردة لم بلزم كالعارية والسكنى ولم لماتل

يزل ملك الواقف عنه كالعارية(')

استدل أصحاب الرأي الثاني القائل بجواز بيعه بالآتي:

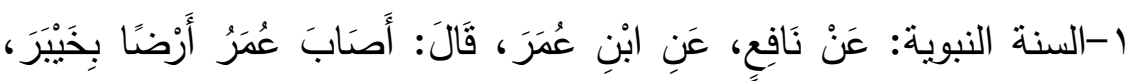

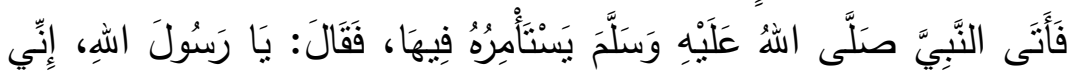

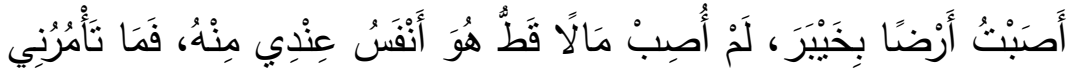

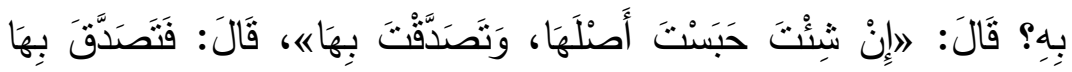

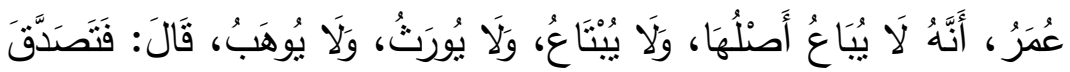

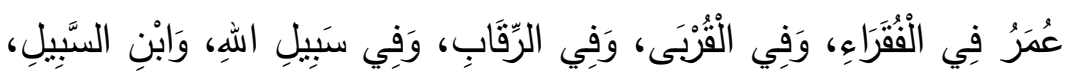

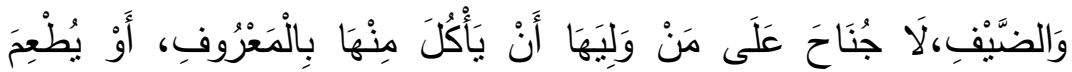

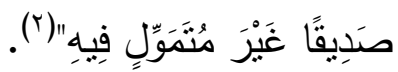
وجه الالالة منه:

أن عمر - رضي الله عنه- اشترط في الوقف الذي أوقفه أن لا يباع ولا

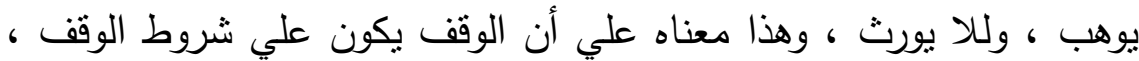

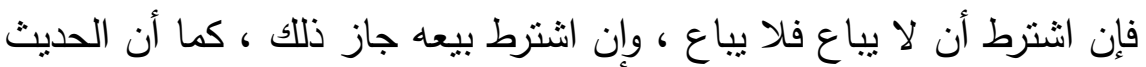
علق الحبس (الوقف ) علي الإرادة ، والتعليق علي الإرادة ينافي اللزوم. ثانيا القياس: بيع الوقف عند اثتراط الواقف جواز البيع جائز قياسا

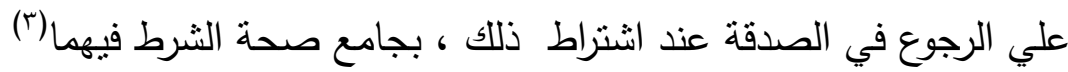

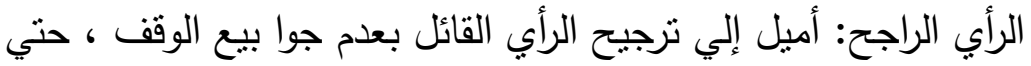

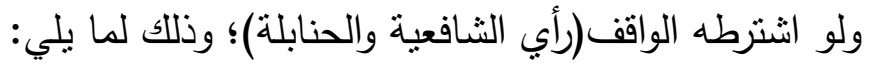

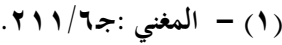

(Y)

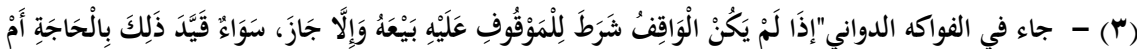

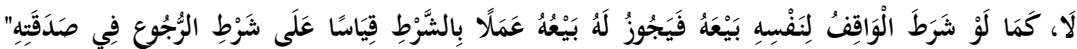




\section{الوقف مقاصده وطرق استثماره}

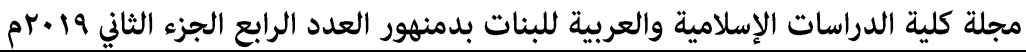

1- مقتضي الوقف اللزوم والتأبيد ، والقول بجواز بيعه لا شك ينافي هذا ،

ولا بحقق المنفعة المرجوة من ورائه .

r- الوقف مقصده الأساسي انتفاع الموقوف عليهم به وبثمرته ، والقول بجواز

اشتراط الحابس بيع الوقف يفوت هذا الغرض الذي من أجله شُرعَ الوقف لون

، وجعل الوقف رهن بإرادة الواقف بكون بعيدا عن تحقيق الوقف لأغراضه

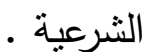

ب- الوقف نقل للملكية(لله سبحانه وتعالي، أو للموقوف عليهم) ، أي أن ملكية

الواقف قد زالت عنه، وبالتالي لا سلطان للحابس علي عين الوقف ،

$$
\text { فكيف يكون له الحق في بيعه!. }
$$

ج- بيع الوقف : بيع الوقف بجنس مثله (الصورة الثالثة).

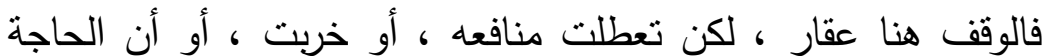

تلعو إلي توسعة مسجد ما ، ، أو لقلة منفعة الوقف ، أو زيادة المصروفات عليه، أو من أجل مصلحة أخري ، فهل يجوز بيع الوقف وشراء عين أخري

تحل مكان عين الوقف المباعة ؟

اختلف الفقهاء في هذه الصورة ، وكان خلافهم علي النحو التالي: الرأي الأول : يري جواز بيع الوقف (وهو لأكثر الحنفية ، وقول لمالك ،

ورواية أبي الفرج عن ماللك ، والمشهور عند الحنابلة ) ('). الرأي الثاني:يري عدم جواز بيع الوقف حتي ولو خرب وتعطلت منافعه(وهو مذهب الثافعية، والمعتمد عند المالكية ، وبعض الحنفية ، ورواية

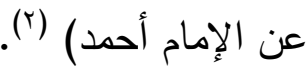

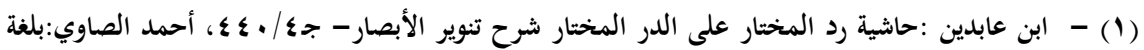

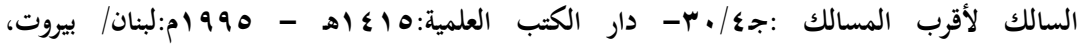

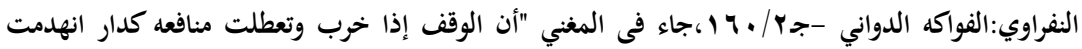

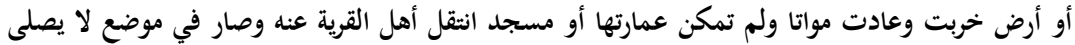

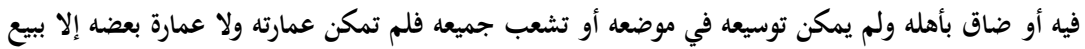

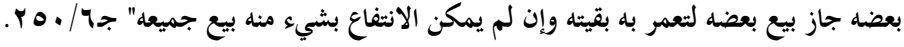

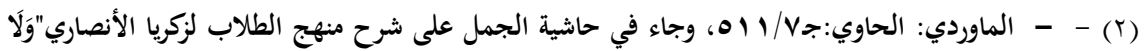

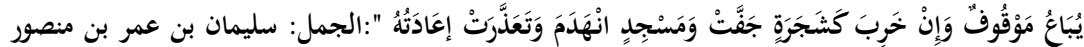

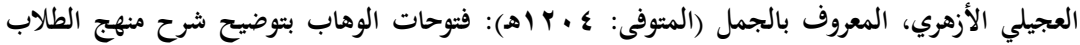

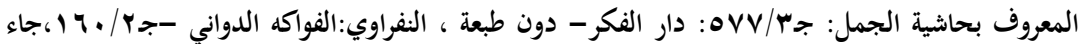




\section{الوقف مقاصده وطرق استثماره}

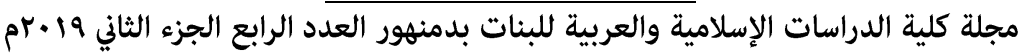

استدل الرأي الأول القائل بجواز بيع الوقف الذي تعطلت منافعه

: (أو خربت : (1) (1)

بالقياس:

ا- أن الوقف يجوز بيعه بالمثل للحاجة ، أو بلا حاجة للمصلحة ،إذا كانت

منفعته أكثر ، قياسا علي جواز استبداله (').

r- قياس بيع الوقف علي جواز استبدال المسجد ، وذلك إذا دعت المصلحة ،

فإذا كان استبدال المسجد جائزا ، فمن باب أولي جواز بيع العقار

الموقوف وشراء بديل آخر مكانه للحاجة(؟) .

استدل الرأي الثاني الذي يري عدم جواز بيع الوقف الذي تخرب :

بالقياس علي العبد المعتق ؛لأن المال الموقوف قد خرج من ملك الواقف

،قياسا علي العبد المعتق لله عز وجل، فيحرم علي المحبس ملك المال،

كما يحرم علي المعتق أن بملك العبد (r).

الرأي الراجح: الرأي القائل بجواز بيع الوقف الذي تعطلت منفعته

$$
\text { أو تخرب ؛ وذللك للأسباب الآتية: }
$$

ا - أن الغرض من الوقف هو دوام المنفعة، واستمرار ثمرته لمن وُقِف عليهم،

وتعطل منفعة الوقف أو خرابه لا يحقق الردف المرجو من الوقف ،فكان

القول بجواز بيعه وشراء عين أخري تحل مكانه هو الأولي بالقبول.

r- تخريب الوقف يترتب عليه انتهاء الوقف ، والقول بجوازه في هذه الحالة

يلأم القول بتأبيد الوقف كودوام المنفعة ، فالبيع فيه استمرارية ودوام

للوقف ، وتجديد له.

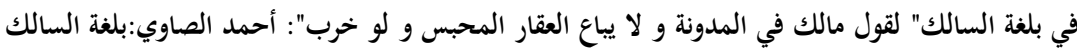

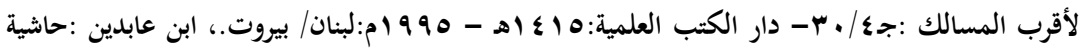

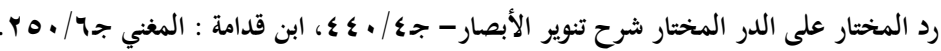

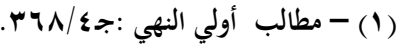

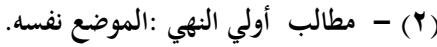

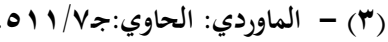




\section{الوقف مقاصده وطرق استثماره}

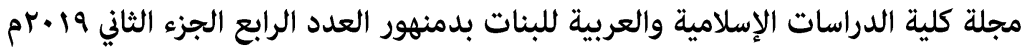

r- الثربعة الغراء نهت عن إضاعة المال ، والتقربط فيه ، وتزك الوقف

مخربا ، وعرضة للضياع بنافي ما دعت إلبه الثربعة من المحافظة علي المال ، فالقول بجواز بيعه في هذه الحالة يتماثي ، وبساير روح الثربعة.

\section{د- بيع الوقف المنقول (الصورة الرابعة).}

بيع الوقف المنقول دون سبب يدعو لذللك لا يجوز ، ما دامت منفعته جارية ، أو لم يتعطل الانتفاع به ، أو قلت منفعته ، أو لم تكن هناك مصلحة راجحة تذعو لذلك.

لكن الخلاف بين الفقهاء في الوقف المنقول فيما إذا تعطلات منافعه ،

أو تخرب ، فهل والحالة هكذا بجوز بيعه ؟

\section{اختلف الفقهاء علي رأيين :}

الرأي الأول: يري جواز بيع الوقف المنقول إذا تعطلت منافعه (وهو

للحنفية، والمعتمد عند المالكية، والأصح عند الثافعية، والحنابلة) (1).

الرأي الثاني: يري أنه لا يجوز بيع الوقف المنقول الذي تعطلت

منافعه(وهو لبعض المالكية ومقابل الأصحح عند الثافعية) (Y). استذل الرأي الأول الذي بري جواز بيع الوقف المنقول بما يلي:

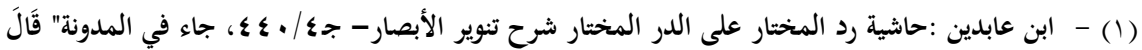

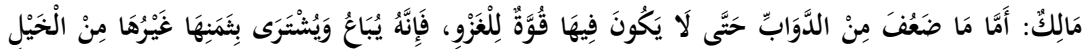

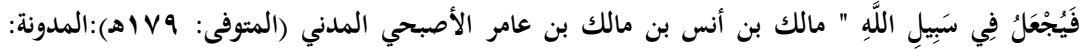

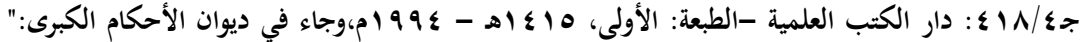

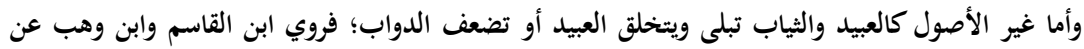

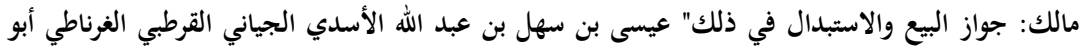

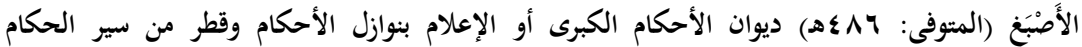

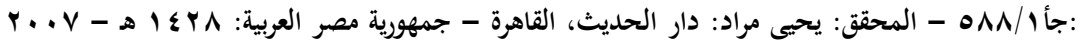

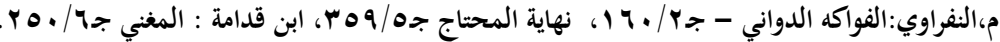

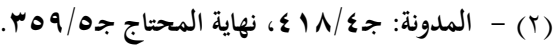




\section{الوقف هقاصده وطرق استثماره}

مجلة كلية الدراسات الإسلامية والعربية للبنات بدمنهور العدد الرابع الجزء الثاني 19 •rمأماره أولا: القياس :

ا- أنه إذا كان بيع الوقف غير المنقول(العقار) جائز ، فمن باب أولي يجوز

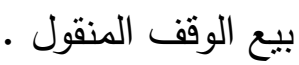
ب- أنه يجوز استبدال الوقف غير المنقول من عقار وغيره ، فيجوز كذلك بيع الوقف المنقول ؛ تحقيقا للمدلحة المنتظرة من وراء الوقف ، ولا بوجد ما يمنع ذللك. ثانيا :المعقول:

أنه إذا تعطلت منافع الوقف المنقول ، ولم يعد صالحا لتحقيق الغاية التي من أجلها وُوِقَ ، فلو قلنا بعدم جواز بيعه تعطل الانتفاع به ، وربما احتاج إلي مصاربف فاقت الحاجة إلبه ، والمنفعة التي تعود منه ، فلذا كان

القول بجواز بيعه من أجل الانتفاع به ، وزيادة ناتج الوقف ، وقلة تكلفته . استدل أصحاب الرأي الثاني القائل بعدم جواز بيع الوقف المنقول

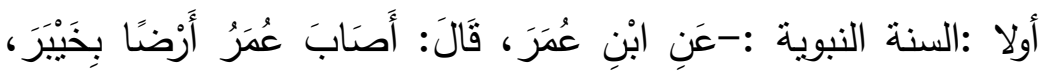

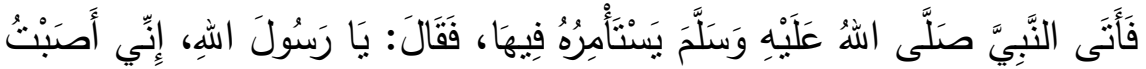

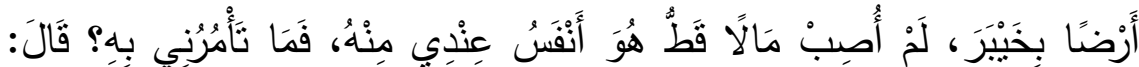

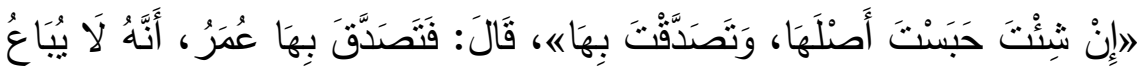

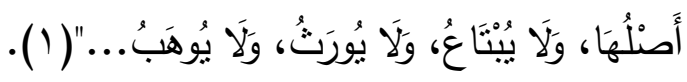

وجه الدلالة منه:أن النبي - صلى الله عليه وسلم- أجاز حبس أصل المال ، ونسبييل الثمرة ، فدل هذا علي خروجه عن ملكه ، فلا يملك منه شيئا ، ولا يملك بيعه (Y). ويندرج تحت هذا عدم جواز بيع الوقف المنقول. ثانيا : القياس:

ا- قياس عدم جواز بيع الوقف المنقول ، علي عدم جواز بيع الربع الموقوف إذا خرب ، فكما لا بستقيم بيع الربع الخرب ، فكذلك لا يستقيم بيع الوقف المنقول.

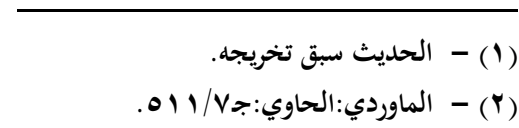




\section{الوقف مقاصده وطرق استثماره}

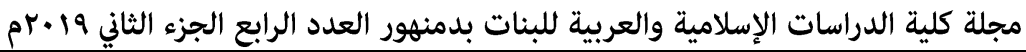

ب- قياس عدم جواز بيع الوقف المنقول علي عدم جواز استبدال الوقف

المنقول والعقار ؛ لأن الوقف يقتضي التأبيد واللزوم، والبيع ينافي ذلك.

الرأي الراجح : أميل إلي ترجيح رأي من قال بجواز بيع الوقف المنقول

إذا تعطلت منفعته ؛ للأسباب التالية:

ا- في تجويز بيعه تحقيق لمصلحة الموقوف عليهم ؛ بيادة العائد من وراء

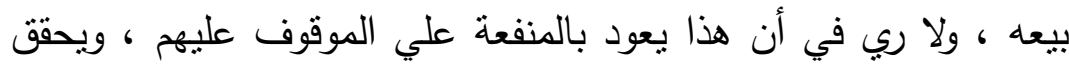
لهم المصلحة.

ب- الأوقاف المنقولة أكثر عُرْضةً من الأوقاف العقاربة للهلاك والضياع والتلف ، فلو قلنا بعدم جواز بيعها لأدي ذلك إلي تفويت المنفعة المرجوة من الوقف ،فالقول بجواز بيعه وإحلال غيره مكانه حفاظ عليه ، وتطويل لأمد استمراره وبقائه ، بل وفيه حفظ للوقف من الضياع. ج - أن الأوقاف المنقولة كثيرا ما تكون مرتبطة ، وتابعة لعقارات موقوفة ، وفي هلاكها ما يؤثز علي هذه الأوقاف ، فالقول بجواز بيعها بعود بالنفع

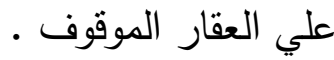

هبة الوقتف

هبة الموقوف لا يجوز لا للقاضى ولا لإدارة الوقف ؛ لمنافاة ذللك لمقتضى عقد الوقف ، وهو قطع التصرف في العين الموقوفة بأسباب

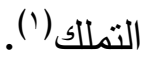




\section{الوقف مقاصده وطرق استثماره}

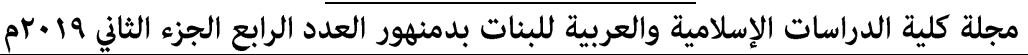

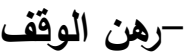

ليس للقاضى أو ناظر الوقف رهن الوقف كذلك شأنه شأن البيع والهبة؛ لأن رهن المال الموقوف يستلزم البيع عند تعذر الوفاء بالدين ، ليستوفى الدائن

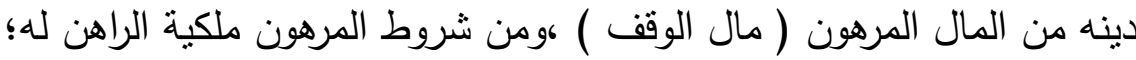

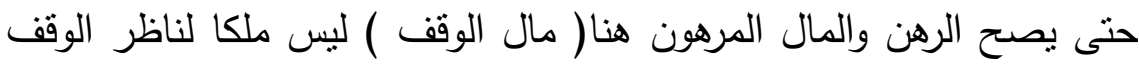

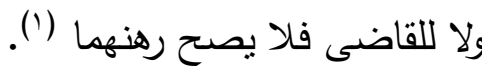

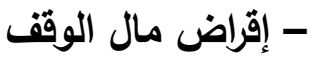
هل يجوز لناظر الوقف اقراض مال الوقف ؟ اختلف الققهاء على النحو التالى :-

المذهب الأول :-برى أنه لا يجوز لناظر الوقف إقراض مال الوقف ، أولف إلا إذا غاب المستحق لمال الوقف ، وخشى تلف الغلة أو ضياعها فيجوز والحالة كذلك إقراضها لملئ ثقة وهذا الرأى للثافعية والحنابلة (؟). المذهب الثانى :- يرى جواز إقراض ناظر الوقف ما فضل من غلة

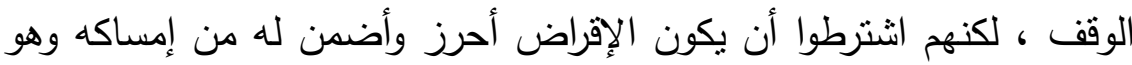

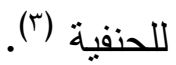

وفي الحقيقة من يتأمل في وجهة نظر المذهبين يتضح له أن الخلاف شكلى بينهما ، فالقول المانع للإقراض أجاز القرض للحاجة ، والقول النافى لهـ لهن

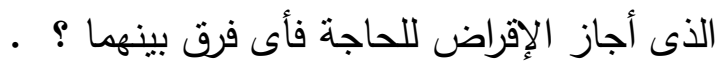

(1) - (1) فاء في المحيط البرهاني"متولي الوقف إذا رهن الوقف بدين لا يصح؛ لأن فيه تعطيل منافع الرهن، فإن سكن

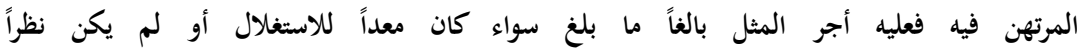

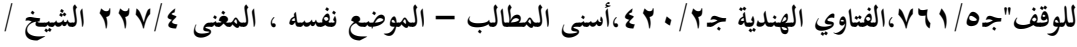

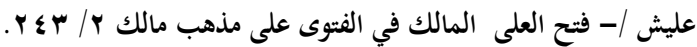

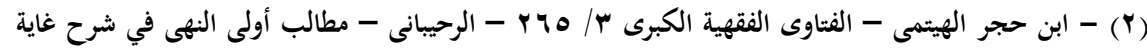
المنتهى إن/

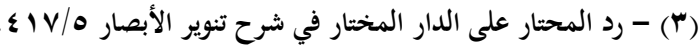




\section{الوقف مقاصده وطرق استثماره}

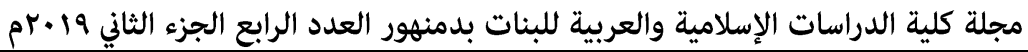

\section{نتائج البحث وتوصياته}

- الوقف لو أحسن استخلاله لقام بدور عظيم فى الحياة المالية ، والاقتصادية

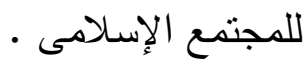

- يساهم الوقف فى تتمية المجتمع وازدهاره وتقدمه فى شتى المجالات ، ويعد مصدرا حيويا لمجالات خيرية كثيرة لا تشملها مظلة الزكاة .

- الوقف نظام مالى إسلامى يهدف إلى تقوية الروابط الاجتماعية بين أفراد

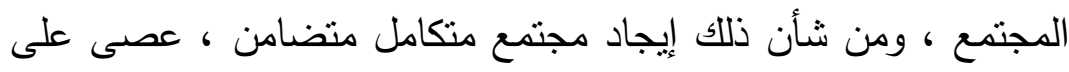

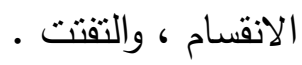

- قام الوقف ، وما زال فى مكنته القيام بذلك بدور متعاظم فى حماية الثغور ، من خلال دعمه للجهاد ، وفى دعم رسالة المسجد ، ورعاية الفقراء.

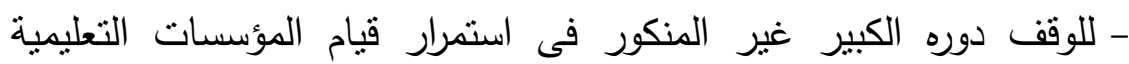

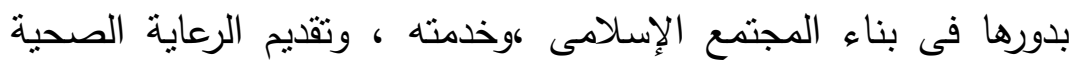
المناسبة لأفراده. - ساهم الوقف فى الحد ومعالجة مشكلة البطالة ، ومظاهر الاحتياج، والعوز

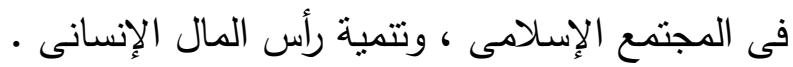

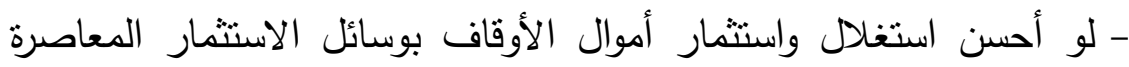

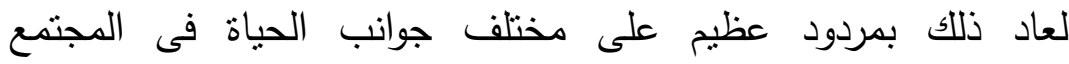

$$
\text { الإسلامى. }
$$

- ينبغى انتقاء إدارة تحسن استخلال مال الوقف وتتميته ، واستثماره ، ومعالجة أوجه الخلل والقصور فى إدارات الأوقاف ، والاستفادة من النظم الحديثة فى تشغيل وإدارة الوقف.

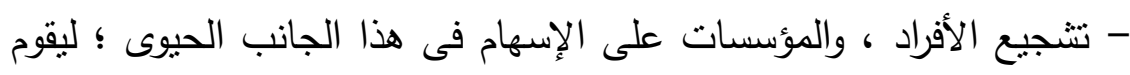

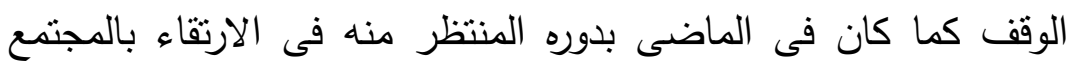

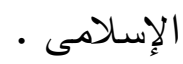

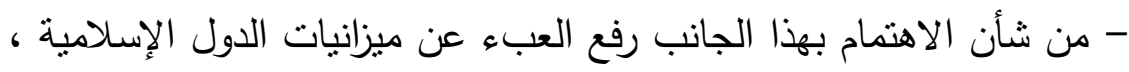

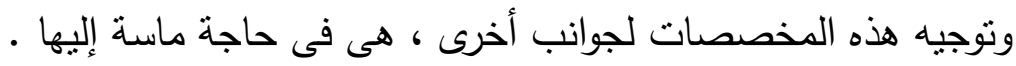




\section{الوقف مقاصده وطرق استثماره}

مجلة كلية الدراسات الإسلامية والعربية للبنات بدمنهور العدد الرابع الجزء الثاني 19 •rم الثماهم

\section{(1) المصادر (1)}

- الأنصاري كشيخ الإسلام / زكريا /أسنى المطالب في شرح روض الطالب-

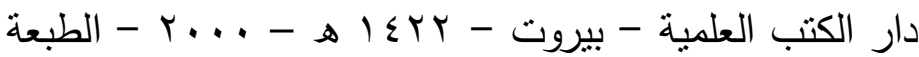

الأولى ، - تحقيق : د . محمد محمد تامر.

- الحطاب - مواهب الجليل - أبو عبدالله محمد بن محمد بن عبدالرحمن

الطرابلسى المغربى - دار الفكر •

د/ حسين شحاته - منهج وأساليب إدارة أموال المؤسسات الوققية.

- الدسوقى - حاثية الدسوقى على الثرح الكبير - شمس الدين الثيخ محمد عرفة الدسوقى - دار إحياء الكتب العربية .

زهدى يكن : الوقف فى الثربعة والقانون - بيروت - دار النهضة العربية .

سعبد عاشور - بحوث فى تاربخ الإسلام وحضارته - الطبعة الأولى - دار عالم الكتب - القاهرة.

- على محيى الدين القرة داغى - الإطار الثرعى للوقف ومقاصده العامة دراسة فقهية تأصيلية .

عبدالعزيز الثناوى : الأزهر جامعا وجامعة- مكتبة الأنجلو المصربة - الطبعة

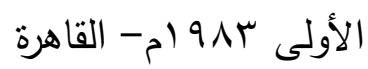

عبداله علوان : التكافل الاجتماعى فى الإسلام - الطبعة الخامسة - دار

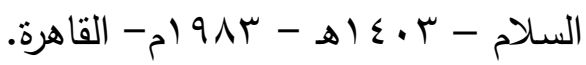

- عبدالله بن الثيخ المحفوظ بن بيه - إعمال المصلحة فى الوقف - مؤسسة

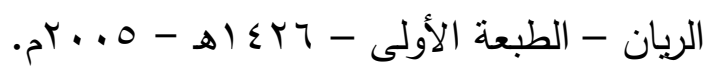

- عبدالرحيم محمد حيزوم - الوقف ودوره فى تمويل المرافق الخدمية عند عجز الميزانية العامة للاولة - المؤتمر الثالث للأوقاف بالمملكة العربية السعودية- - . باء اهـ - 9 . . بم.

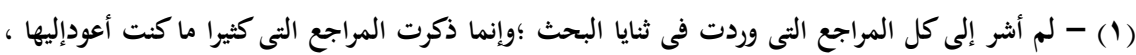

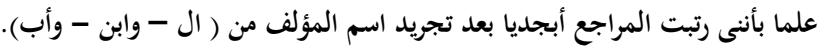




\section{الوقف مقاصده وطرق استثماره}

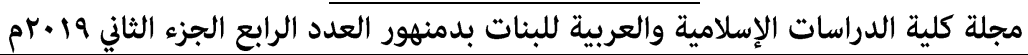

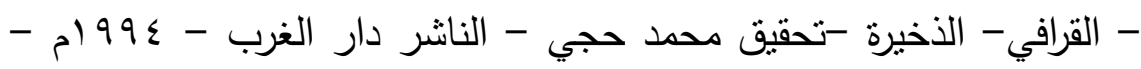

$$
\text { بيروت. }
$$

- ابن قدامة - المغنى - موفق الدين عبداله بن أحمد (ابن قدامة )- دار

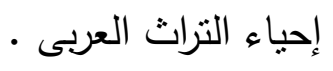

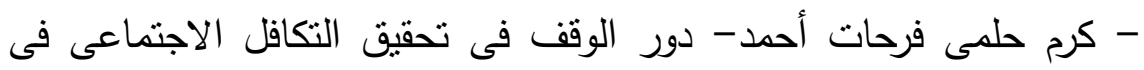

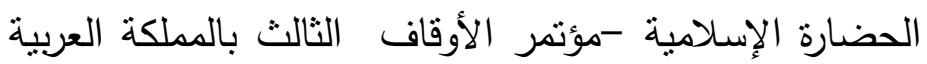

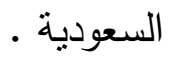

- محمد أبوزهرة - محاضرات فى الوقف -الطبعة الثانية- دار الفكر العربى -

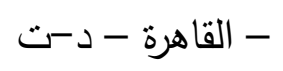

- محمد قدرى بانشا - قانون العدل والإنصاف فى القضاء على مشكلات

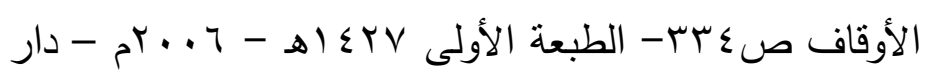

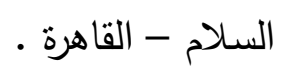

- محمد الغزالى - خلق المسلم - الطبعة العاشرة هــــمة - نهضة مصر

$$
\text { للطباعة . خلى }
$$

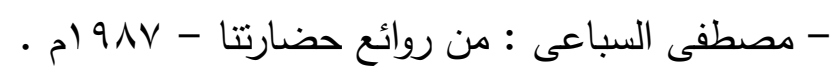

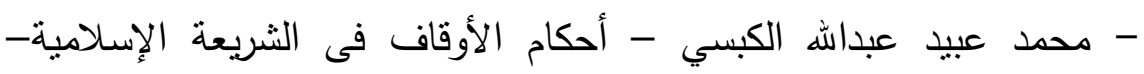

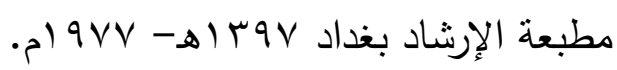

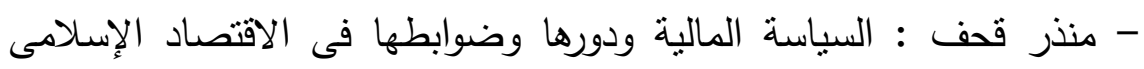

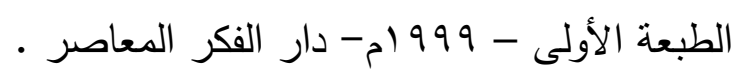

- محمد عبد الحليم عمر - قضايا ومشكلات المحاسبة على الوقف - ورقة

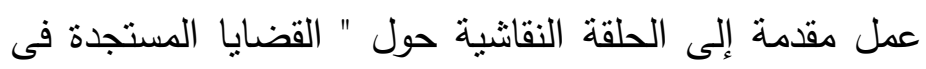

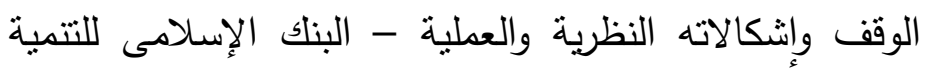

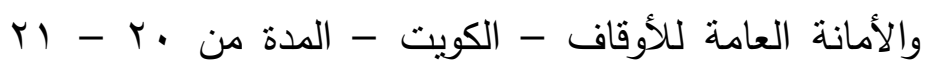

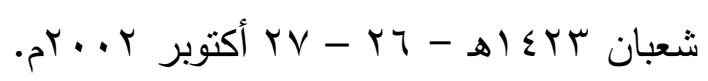

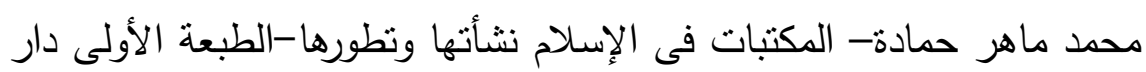

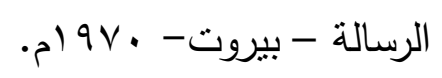




\section{الوقف هقاصده وطرق استثماره}

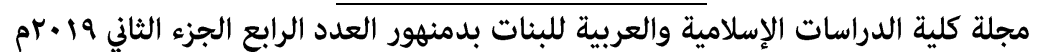

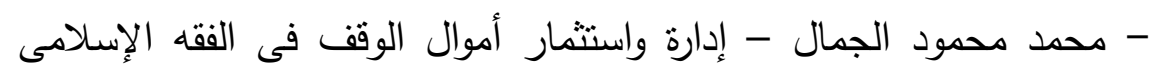
وأنظمة الإدارة العامة للأوقاف القطربة - مطبوعات الإدارة

العامة للأوقاف - دولة قطر - الإدة العهد

- ابن نجيم - البحر الرائق - زين الدين بن إبراهيم بن محمد (ابن نجيم) -

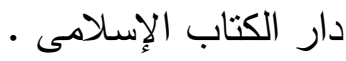

- الناجى لمين - الوقف وتتميته وخطورة اندثاره - دار الكلمة للنشر والتوزيع

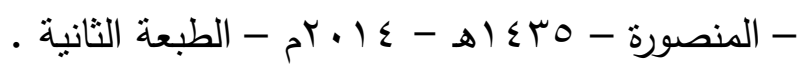

- ابن الهمام - شرح فتح القدير - كمال بن عبدالواحد (ابن الهمام) دار الفكر ه 